\title{
EFFECTS OF A WETLAND ON QUALITY OF NATTY POND BROOK, MASSACHUSETTS, 1985-86
}

By Nancy C. Suurballe

\section{U.S. GEOLOGICAL SURVEY}

Water-Resources Investigations Report 91-4144

Prepared in cooperation with the

MASSACHUSETTS DEPARTMENT OF ENVIRONMENTAL PROTECTION, DIVISION OF WATER POLLUTION CONTROL

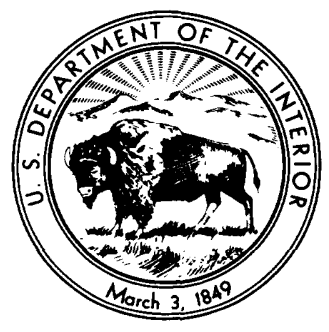

Marlborough, Massachusetts 1992 


\section{U.S. DEPARTMENT OF THE INTERIOR}

MANUEL LUJAN, JR., Secretary

U.S. GEOLOGICAL SURVEY

Dallas L. Peck, Director

For additional information write to:

District Chief

Massachusetts - Rhode Island District

U.S. Geological Survey

Water Resources Division

28 Lord Rd., Suite 280

Marlborough, MA 01752
Copies of this report can be purchased from:

U.S. Geological Survey Books and Open-File Reports Box 25425

Federal Center

Denver, CO 80225 


\section{CONTENTS}

Page

Abstract $\ldots \ldots \ldots \ldots \ldots \ldots \ldots \ldots \ldots \ldots \ldots \ldots \ldots \ldots \ldots \ldots \ldots \ldots \ldots \ldots \ldots$

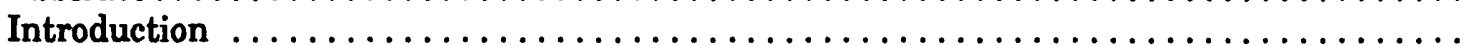

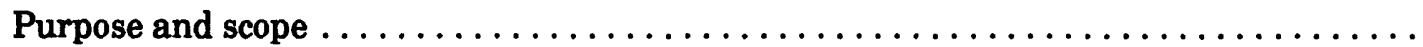

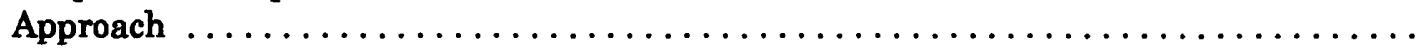

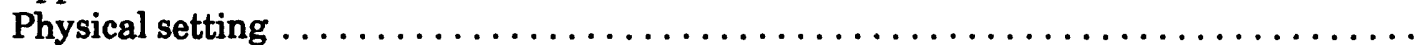

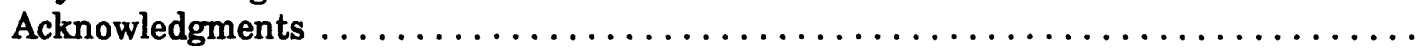

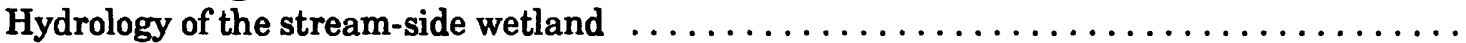

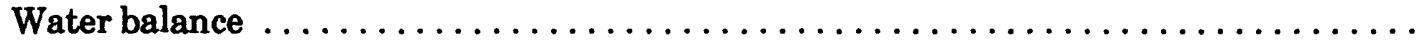

Measurement precision . . . . . . . . . . . . . . . . . . . . . . . . . . . .

Effects of the wetland on the quality of Natty Pond Brook $\ldots \ldots \ldots \ldots \ldots \ldots \ldots \ldots$

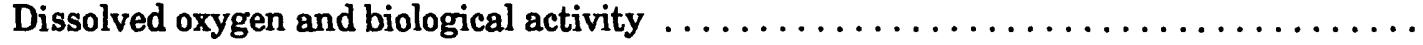

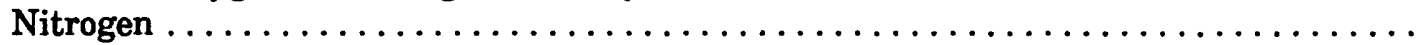

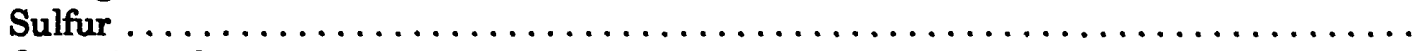

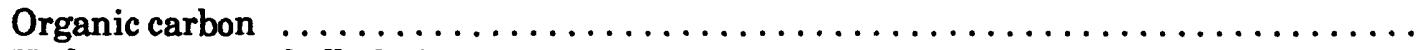

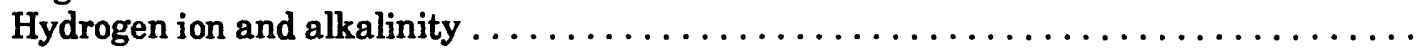

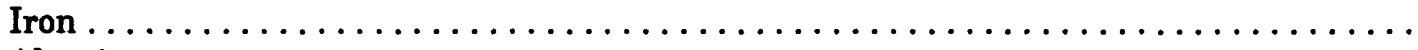

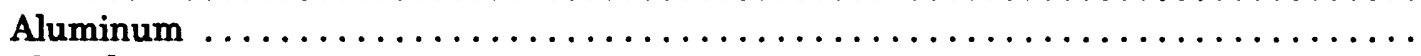

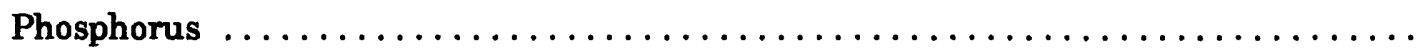

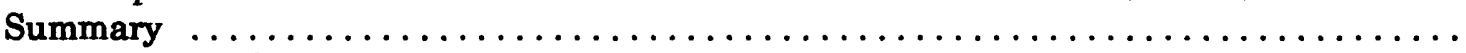

References cited .
1

2

4

4

5

7

7

10

11

21

31

34

36

38

40

45

45

48

50

\section{ILLUSTRATIONS}

Figure 1. Map showing hydrologic-data and water-quality-data sites and surface drainage divides of Natty Pond Brook basin, Massachusetts ............ 3

2. Map showing wetland-vegetation types and locations of stations used to measure dissolved-oxygen productivity in stream reaches of Natty Pond Brook, Massachusetts

3. Graph showing water levels in shallow and deep wells screened in peat deposits in Natty Pond Brook wetland, July 18-25, $1986 \ldots \ldots \ldots \ldots \ldots \ldots$.

4. Conceptual flow diagram through a wetland stream reach $\ldots \ldots \ldots \ldots \ldots \ldots \ldots .8$

5. Graph showing seasonal distribution of water-balance components, $1985 \ldots \ldots \ldots \ldots$

6. Graph showing seasonal distribution of water-balance components, $1986 \ldots \ldots \ldots 11$

7. Graph showing seasonal distribution of water-balance components, as percentages of total annual water volume, Natty Pond Brook, Massachusetts, 1985 and 1986.

8. Graph showing precipitation near, and water levels in, a well in the wetland, December 1984 through October 1985 


\section{ILLUSTRATIONS - (Continued)}

Figure

9. Graph showing precipitation near, and water levels in, a well in the wetland, November 1985 through December 1986

Page

10. Graph showing discharge measured during four seepage runs at numbered water-quality sites on Natty Pond Brook, Massachusetts

11. Hydrographs showing daily mean streamflow and seasonal categories for waterquality sites on Natty Pond Brook, Massachusetts, November 1,1984 through October $31,1986 \ldots \ldots \ldots \ldots \ldots \ldots \ldots \ldots \ldots$

12. Map showing time-of-travel data-collection sites and surface-drainage divides of hydrologic-data sites of Natty Pond Brook basin, Massachusetts . . . . .

13. Graph showing centroid travel times of dye cloud from headwater to numbered time-of-travel sites on Natty Pond Brook, Massachusetts . . . . . . . . . . . . . .

14. Graph showing seasonal distribution of streamflow, by individual stream reach, for Natty Pond Brook, Massachusetts, 1985 and 1986 . . . . . . . . . . . .

15-26. Graphs showing seasonal discharge of:

15. Dissolved oxygen, by individual stream reach, for Natty Pond Brook, Massachusetts, 1985 and 1986

16. Dissolved ammonium as nitrogen, by individual stream reach, for Natty Pond Brook, Massachusetts, 1985 and 1986

17. Dissolved nitrite plus nitrate as nitrogen, by individual stream reach, for Natty Pond Brook, Massachusetts, 1985 and 1986 . . . . . . . . . . .

18. Dissolved sulfate, by individual stream reach, for Natty Pond Brook, Massachusetts, 1985 and 1986

19. Dissolved organic carbon, by individual stream reach, for Natty Pond Brook, Massachusetts, 1985 and 1986

20. Suspended organic carbon, by individual stream reach, for Natty Pond Brook, Massachusetts, 1985 and 1986

21. Total hydrogen ion, by individual stream reach, for Natty Pond Brook, Massachusetts, 1985 and 1986

22. Total alkalinity as calcium carbonate, by individual stream reach, for Natty Pond Brook, Massachusetts, 1985 and 1986 . . . . . . . . . . .

23. Dissolved iron, by individual stream reach, for Natty Pond Brook, Massachusetts, 1985 and 1986

24. Total iron, by individual stream reach, for Natty Pond Brook, Massachusetts, 1985 and 1986

25. Dissolved aluminum, by individual stream reach, for Natty Pond Brook, Massachusetts, 1985 and 1986

26. Dissolved hydrolyzable plus orthophosphate as phosphorous, by individual stream reach, for Natty Pond Brook, Massachusetts, 1985 and 1986 


\section{TABLES}

Page

Table 1. Streamflow-gaging stations on Natty Pond Brook, Massachusetts .......... 4

2. Water balances for Natty Pond Brook wetland, November 1, 1984 through October $31,1986 \ldots \ldots \ldots \ldots \ldots \ldots \ldots \ldots \ldots \ldots \ldots \ldots \ldots \ldots$

3. Maximum, median, and minimum values of chemical concentrations and properties, by reach, from Natty Pond Brook, Massachusetts, from November 1, 1984 through October 31, 1986

4. Characteristics of the eight time periods used to integrate constituent loads for Natty Pond Brook, Massachusetts, November 1, 1984 through October 31, 1986

5. Comparison of water-quality constituent concentrations and specific conductance in ground water from wells screened in sand-and-gravel and peat deposits, Natty Pond Brook wetland

6. Water-quality constituent loads from direct precipitation input to wetland, for Natty Pond Brook, November 1, 1984 through October 31, 1986 . . . . . . . .

7. Summary of travel-time data for dye-tracer sites on Natty Pond Brook,

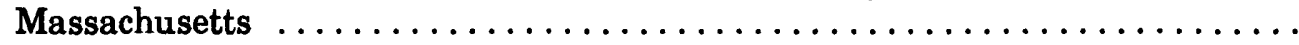

8. Summary of computed travel-time data, by individual stream reach, at about 90 percent flow-duration on Natty Pond Brook, Massachusetts ............

9. Effects of wetland areas on stream-water constituent loads in individual stream reaches, on Natty Pond Brook, Massachusetts ............. 28

10. Reach characteristics and results of tracer and oxygen-productivity studies ..... 30

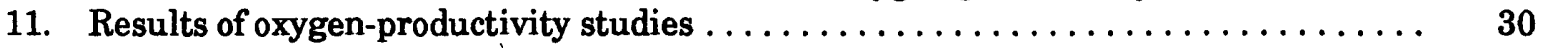




\begin{tabular}{|c|c|c|}
\hline Multiply & By & To obtaln \\
\hline \multicolumn{3}{|c|}{ Length } \\
\hline $\begin{array}{l}\text { millimeter }(\mathrm{mm}) \\
\text { meter }(\mathrm{m}) \\
\text { kilometer }(\mathrm{km})\end{array}$ & $\begin{array}{l}0.03937 \\
3.281 \\
0.6214\end{array}$ & $\begin{array}{l}\text { inch } \\
\text { foot } \\
\text { mile }\end{array}$ \\
\hline \multicolumn{3}{|c|}{ Area } \\
\hline $\begin{array}{l}\text { square kilometer }\left(\mathrm{km}^{2}\right) \\
\text { hectare }(\mathrm{ha})\end{array}$ & $\begin{array}{l}0.3861 \\
0.003861\end{array}$ & $\begin{array}{l}\text { square mile } \\
\text { square mile }\end{array}$ \\
\hline \multicolumn{3}{|c|}{ Volume } \\
\hline $\begin{array}{l}\text { cubic meter }\left(\mathrm{m}^{3}\right) \\
\text { liter }(\mathrm{L})\end{array}$ & $\begin{array}{l}35.31 \\
33.82\end{array}$ & $\begin{array}{l}\text { cubic foot } \\
\text { ounce, fluid }\end{array}$ \\
\hline \multicolumn{3}{|c|}{ Flow } \\
\hline $\begin{array}{l}\text { meter per second }(\mathrm{m} / \mathrm{s}) \\
\text { cubic meter per second } \\
\left(\mathrm{m}^{3} / \mathrm{s}\right)\end{array}$ & $\begin{array}{l}3.281 \\
35.31\end{array}$ & $\begin{array}{l}\text { foot per second } \\
\text { cubic foot per second }\end{array}$ \\
\hline \multicolumn{3}{|c|}{ Mass } \\
\hline milligram (mg) & 35.27 & ounce \\
\hline $\begin{array}{l}\text { gram per cubic meter per hour } \\
\left(\left(\mathrm{g} / \mathrm{m}^{3}\right) / \mathrm{h}\right)\end{array}$ & 0.002205 & pound per cubic meter per hour \\
\hline $\begin{array}{l}\text { gram per cubic meter per day } \\
\left(\left(\mathrm{g} / \mathrm{m}^{3}\right) / \mathrm{d}\right)\end{array}$ & 0.002205 & pound per cubic meter per day \\
\hline kilogram (km) & 2.205 & pound \\
\hline \multicolumn{3}{|c|}{ Temperature } \\
\hline degree Celsius $\left({ }^{\circ} \mathrm{C}\right)$ & ${ }^{\circ} \mathrm{F}=1.8 \mathrm{x}^{\circ} \mathrm{C}+32$ & degree Fahrenheit \\
\hline
\end{tabular}




\title{
Effects of a Wetland on Quality of Natty Pond Brook, Massachusetts, 1985-86
}

\author{
By Nancy C. Suurballe
}

\section{ABSTRACT}

Water balances and water-quality loads were determined for a palustrine wetland of about 200 hectares. Annual upland surface- and ground-water inputs were $2,060 \mathrm{~mm}$ (millimeters) in 1985 and 3,640 $\mathrm{mm}$ in 1986. Annual precipitation amounts were $1,010 \mathrm{~mm}$ in 1985 and $1,020 \mathrm{~mm}$ in 1986. Annual evapotranspiration outputs were $570 \mathrm{~mm}$ in 1985 and $550 \mathrm{~mm}$ in 1986. Gaged annual surface-runoff outputs from the wetland were $2,420 \mathrm{~mm}$ in 1985 and $3,910 \mathrm{~mm}$ in 1986. Changes in the amount of surfaceand ground water stored in the wetland were small relative to the other volumes in the water balance. Seasonal water balances were used to demonstrate the hydrologic effects of the wetland on the transport of loads of dissolved constituents to the stream.

Water enters the wetland from adjacent uplands and displaces water stored in peat deposits. Following residence time ranging from weeks to months in the organic peat, water from the wetland discharges to the stream, and increases stream loads of dissolved organic substances, iron, and other constituents associated with peat water chemistry. The oxygen demand of these substances decreases dissolved-oxygen concentrations to about 30 percent of saturation in some wetland reaches of the stream. Chemical discharges, per hectare, from the wetland in 1985 were $185 \mathrm{~kg}$ (kilograms) of organic carbon; $29 \mathrm{~kg}$ of iron; $3.3 \mathrm{~kg}$ of dissolved nitrogen; and $0.42 \mathrm{~kg}$ of dissolved phosphorous. During 1986, yields were $246 \mathrm{~kg}$ of organic carbon; $36 \mathrm{~kg}$ of iron; $7.2 \mathrm{~kg}$ of dissolved nitrogen; and $0.47 \mathrm{~kg}$ of dissolved phosphorous. Differences in the discharge of water-quality contituents through individual wetland stream reaches are attributed to chemical reactions that occur in the stream-side wetland. The effects of the wetland on stream-water quality are directly related to residence time of water in a wetland stream reach: the longer the water is in the reach, the greater the effect of the wetland.

\section{INTRODUCTION}

Wetlands play an important role in the hydrology of contiguous streams. Wetlands reduce peak streamflows by temporarily storing surface water in topographically low areas and within the near surface horizons of wetland sediments. Because of high evapotranspiration rates during the warm-weather months, wetlands can reduce streamflow during lowflow conditions. Because of low stream gradients and in-channel vegetation, streamflow velocities through wetlands decrease. Consequently, the residence time of stream water increases through wetland reaches. Wetlands may affect the quality of contiguous stream waters by increasing the rate of sediment accretion, facilitating the transport of nutrients between wet- 
land vegetation and streams, and providing favorable conditions for biochemical changes in water quality.

Water-quality data collected by the Massachusetts Division of Water Pollution Control (MDWPC) indicate that dissolved-oxygen (DO) concentrations can decrease and nutrient concentrations can increase along stream reaches contiguous to wetland areas. Dissolved-oxygen concentrations are sometimes lower than the Massachusetts minimum water-quality criteria required to support a stream's designated use (Massachusetts Division of Water Pollution Control, 1986). These reduced DO concentrations indicate that biological, chemical, and benthic oxygen demands, together with the respiration of aquatic organisms, may exceed the photosynthetic production and physical reaeration of oxygen in wetland stream reaches.

The MDWPC relies on DO models to evaluate the water quality of streams throughout Massachusetts. However, the models do not reliably predict DO concentrations in streams that are contiguous to wetlands. There is a need to measure the effects and describe the processes under which wetlands affect stream-water quality so that these effects can be incorporated in DO models.

Wetlands affect stream-water quality through the complex interactions of physical, chemical, and biological processes. The movement of water between a wetland and stream system is a major factor governing these processes. Precipitation, upland runoff, evapotranspiration, ground-water discharge and recharge, and other hydrologic characteristics such as depth and duration of flooding, flow velocity, and residence time are the abiotic factors that have the greatest effect on wetland processes (Mitsch and Gosselink, 1986, p. 55). Depending on the flow regime and the season of the year, stream water may transport dissolved and suspended constituents to or from wetland areas. The effect of wetlands on stream-water quality can be described by relating changes in chemical loads to or from the wetland to seasonal variations in the water balance.

The U.S. Geological Survey in cooperation with the Massachusetts Department of Environmental Protection, Division of Water Pollution Control conducted a study from October 1984 to September 1987 to assess the hydrologic and chemical effects of a wetland on a stream in Central Massachusetts. It was anticipated that the information developed by the study would result in an improved understanding of how stream-side wetlands affect stream-water quality in Massachusetts and in the Northeastern United States.

\section{Purpose and Scope}

This report describes the effects of a nearly 200 ha wetland on the hydrology and chemistry of Natty Pond Brook which flows through the wetland (fig. 1). Chemical loads of the stream were examined for various hydrologic and seasonal conditions and related to chemical and biological processes that occur in the contiguous wetland system. Changes in DO concentration in the stream were related to physical and hydrologic characteristics of the wetland system. Water balances for the wetland were prepared using data collected from November 1984 through October 1986.

Streamflow volumes and chemical and physical characteristics were measured in four stream reaches of the Natty Pond Brook basin. This information was used to estimate transport and retention of nutrients and other chemical loads within the wetland. The basin was divided into four subbasins (fig. 1) to determine net changes in chemical loads along three stream reaches affected by wetlands. The headwater subbasin at the upstream end of the wetland is the area above the wetland and first streamflow-gaging station. Each of the succeeding downstream subbasins represents the drainage area between two streamflow-gaging stations. The station name and identification number for each of the four stations (Q1-Q4), along with wetland, upland, and total intervening drainage areas are given in table 1.

Chemical discharges for each subbasin were calculated for eight time periods in different hydrologic and seasonal conditions. These discharges were related to changes in quantity of flow, season of the year, and location within the wetland.

The effects of a number of other physical, hydrological, and biological processes on stream water were also investigated. Determinations of water-residence times were made for each reach of Natty Pond Brook and related to changes in chemical loads and DO concentrations. Rates of physical reaeration, photosynthesis, and respiration were measured to compare their effects on DO concentrations in the stream water. 


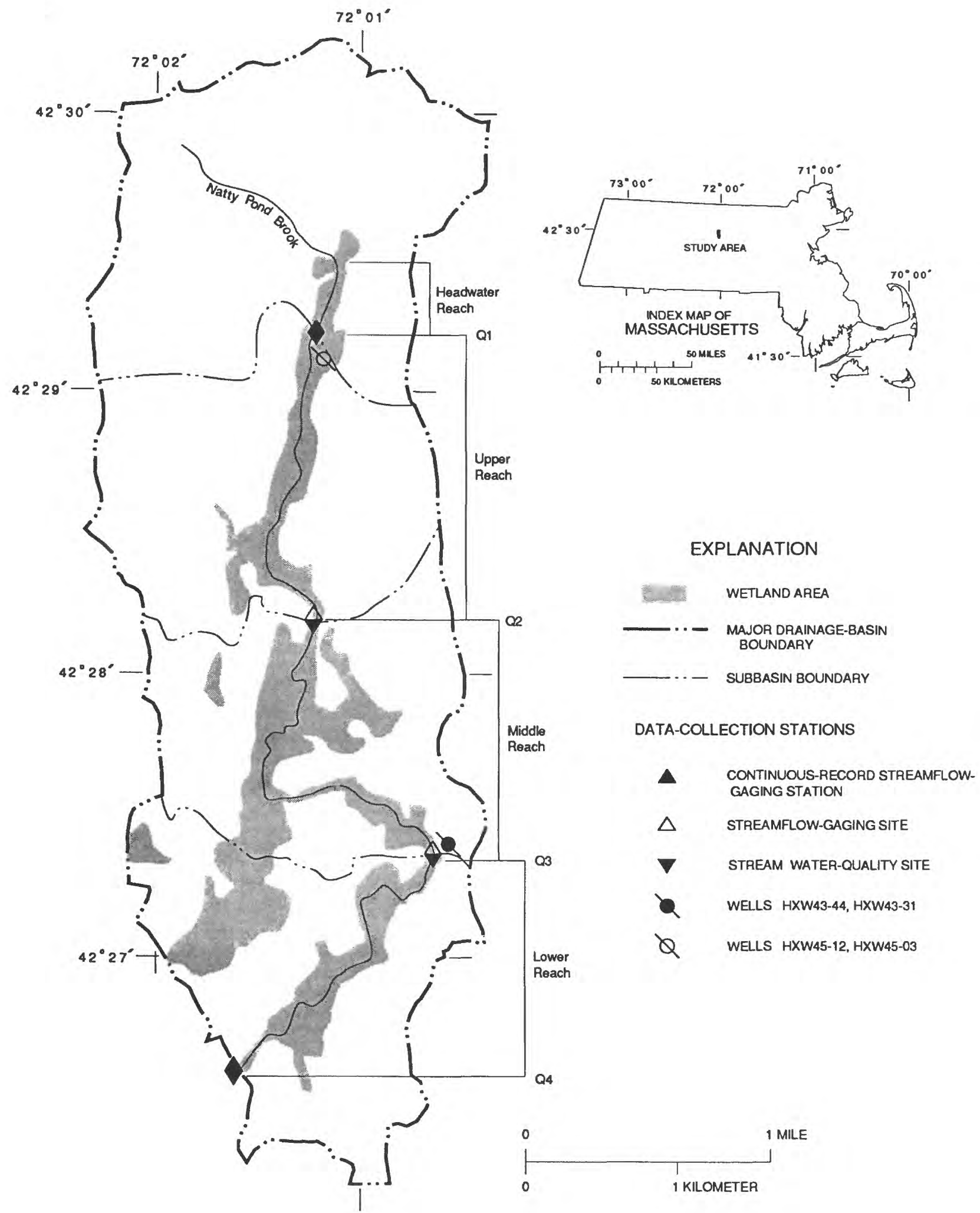

Figure 1.--Hydrologic-data and water-quality-data sites and surface drainage divides of Natty Pond Brook basin, Massachusetts. 
Table 1.--Streamflow-gaging stations on Natty Pond Brook, Massachusetts

\begin{tabular}{lcc|cc}
\hline $\begin{array}{c}\text { Station name and } \\
\text { identification number }\end{array}$ & $\begin{array}{c}\text { Wetland intervening } \\
\text { drainage area, } \\
\text { in square kilometers }\end{array}$ & $\begin{array}{c}\text { Upland intervening } \\
\text { drainage area, } \\
\text { in square kilometers }\end{array}$ & $\begin{array}{c}\text { Total intervening } \\
\text { drainage area, } \\
\text { in square kilometers }\end{array}$ & $\begin{array}{c}\text { Percentage of wetland in } \\
\text { total intervening } \\
\text { drainage area }\end{array}$ \\
\hline $\begin{array}{l}\text { Natty Pond Brook New } \\
\text { Templeton Road (DS) } \\
\text { near Hubbardston, } \\
\text { Mass. } \\
\text { Station Q1 }\end{array}$ & 0.084 & 4.14 & 4.22 & 2 \\
$\begin{array}{l}\text { Natty Pond Brook at } \\
\text { Hubbardston, Mass. } \\
\text { Station Q2 }\end{array}$ & .46 & 3.06 & & \\
$\begin{array}{l}\text { Natty Pond Brook at } \\
\text { Dirt Road at } \\
\text { Hubbardston, Mass. } \\
\text { Station Q3 }\end{array}$ & & & & \\
$\begin{array}{l}\text { Natty Pond Brook near } \\
\text { Hubbardston, Mass. } \\
\text { Station Q4 }\end{array}$ & .751 & 2.46 & 3.52 & 23 \\
\hline
\end{tabular}

\section{Approach}

A number of assumptions were made in this study to define streamflow volumes and chemical loads entering the wetland area from the headwater subbasin. The ground-water divides of the subbasin were assumed to be essentially the same as the surface water divides. All ground-water and surfacewater inputs to the wetland from the headwater subbasin were assumed to be measurable as streamflow passing the gage at Q1 (fig. 1). Underflow was assumed to be negligible in comparison to streamflow passing the gage, as indicated by a very flat ground water hydraulic gradient near Q1. Only 2 percent of this subbasin is characterized by wetlands (table 1). Streamflow and chemical loads computed for the upland subbasin at Q1 were used to estimate inflow and chemical inputs to the wetland from ungaged upland areas in the drainage basins of the other reaches.

It was assumed that no surface flow and negligible underflow bypass the other three measurement stations Q2, Q3, and Q4 in figure 1. Chemical loads computed for these stations were used to compute changes in chemical loads as the stream flows through the wetland. On the basis of the topography and the presence of bedrock outcroppings, Q4 is assumed to intercept all surface- and ground-water discharge for the entire basin. Therefore, chemical loading to the stream at Q4 is expected to reflect the sum of geochemical and biological processes occurring in the wetland.

The annual water-balance period was selected to begin in November and end in October, so that change in storage would be minimal. Estimates of potential evapotranspiration (Thornthwaite and Mather, 1957) assume for simplicity that all soil moisture is available for plants, and that soil moisture is always at field capacity. It was further assumed that the wetland system had adequate water supply, and therefore, actual evapotranspiration is equal to potential evapotranspiration (Mitsch and Gosselink, 1986, p. 75).

\section{Physical Setting}

The wetland comprises about $2 \mathrm{~km}^{2}$ (200 ha) of the Natty Pond Brook 14-km² (1400-ha) drainage basin. About $10 \mathrm{~km}$ of the stream meander over a linear distance of $6 \mathrm{~km}$ through the wetland. Streamflow velocities through the wetland are slow 
(generally less than $.03 \mathrm{~m} / \mathrm{s}$ ) because of the low gradient of the stream channel $(0.002 \mathrm{~m} / \mathrm{m})$. Consequently, a particle of water in the stream may take as long as 17 days to traverse the wetland.

The wetland is in a valley between upland areas composed mainly of glacial till. Ice-contact materials were deposited in the valley during melting of stagnant glacial ice, and consist of stratified sand and coarse gravel up to $12 \mathrm{~m}$ thick (Alden, 1924, pl. VI). Lenses of silt or clay, a few centimeters to more than $1 \mathrm{~m}$ thick, were recorded in lithologic logs of test-wells and can be seen in sand-and-gravel mining areas within the valley.

Land use in upland areas of the basin consists of forest with some agricultural and open land. Only about 5 percent of the upland is tilled; therefore, fertilizer from agricultural land is not a significant source of nutrients to the wetland system. Other land uses that can affect stream-water quality, such as waste-disposal areas and industrial or commercial facilities, comprise only approximately 5 percent of the basin (Resource Mapping-Land Use Information Systems, 1985). Anthropogenic effects on streamwater quality are assumed to be minor.

The wetland is a palustrine system: an inland, freshwater wetland dominated by trees, shrubs, and persistent emergent vegetation (fig. 2). Much of the wetland is underlain by peat (Alden, 1924, pl. VI). Natty Pond Brook flows over this organic soil layer, which is about $1 \mathrm{~m}$ to more than $6 \mathrm{~m}$ thick. The peat at the surface can be described as live, consisting of undecomposed mosses with a high-percentage of fiber and a low bulk density. At depths greater than $1 \mathrm{~m}$, the peat is relatively decomposed and has a low percentage of fiber and a high bulk density.

Natty Pond Brook and the contiguous wetland can be categorized according to trophic state. Prior to entering the wetland system, Natty Pond Brook is oligotrophic with a DO concentration at or near saturation, high water transparency, and low nutrient concentrations. As it flows through the wetland, Natty Pond Brook becomes increasingly dystrophic. Mineralization of organic matter by microbial action and chemical oxidation dominates the amount of oxygen consumed in a dystrophic system (Miles and Brezonik, 1981, p. 1094). Also, in shallow aquatic environments typical of dystrophic systems, the area of contact between the water and sediment is greater than that of deep-water basins, causing color values and concentrations of humic substances and organic carbon to increase. Chemical and biological oxidation of the humic material cause downstream DO concentrations to decrease.

In wetlands, the chemistry of water primarily is determined by its interaction with wetland soils. Water stored in peat deposits may be originally derived from precipitation recharge, out-of-channel flooding, and ground-water discharge. Whatever its origin, this water remains in contact with peat soil for prolonged periods, which increases the concentrations of dissolved organic substances, including humic and fulvic acids (McKnight and others, 1985, p. 1350). As water in peat deposits becomes displaced by precipitation and surface- and ground-water inflow, it discharges to the stream in a gradual and constant manner. In Natty Pond Brook, an upward vertical gradient existed within the peat zone beneath the stream during receding flow, as indicated by head differences in shallow and deep wells (fig. 3). This upward gradient and an increase in stream discharge with stream length confirms that ground water, although retarded by the dense, low-permeability peat layer, discharges to the stream through the peat deposits. Both lateral and upward ground-water flow is toward the stream (fig. 4).

During precipitation or snowmelt, overland and subsurface flow from upland areas also contribute to streamflow. The runoff enters the wetland from areas along the upland boundary (fig. 4), and displaces water stored in the peat that then discharges into the stream. The concept of overland and subsurface flow entering a basin and displacing stored water has been documented by Sklash and others (1976, p. 281), Martinec (1975, p. 496), Martinec and others (1974), and Freeze (1972, p. 1275).

\section{Acknowledgments}

The author expresses appreciation to the U.S. Army Corps of Engineers at the Barre Falls Dam, which regularly collected the climatological data; the Hubbardston Highway Department; the Metropolitan District Commission; and other landowners in Hubbardston, Massachusetts, who provided access to their property to operate streamflow-gaging stations, to monitor wells, and to collect water samples. Special thanks go to A. J. Screpetis, Massachusetts Department of Environmental Protection, Division of Water Pollution Control, who encouraged the study of wetlands. 


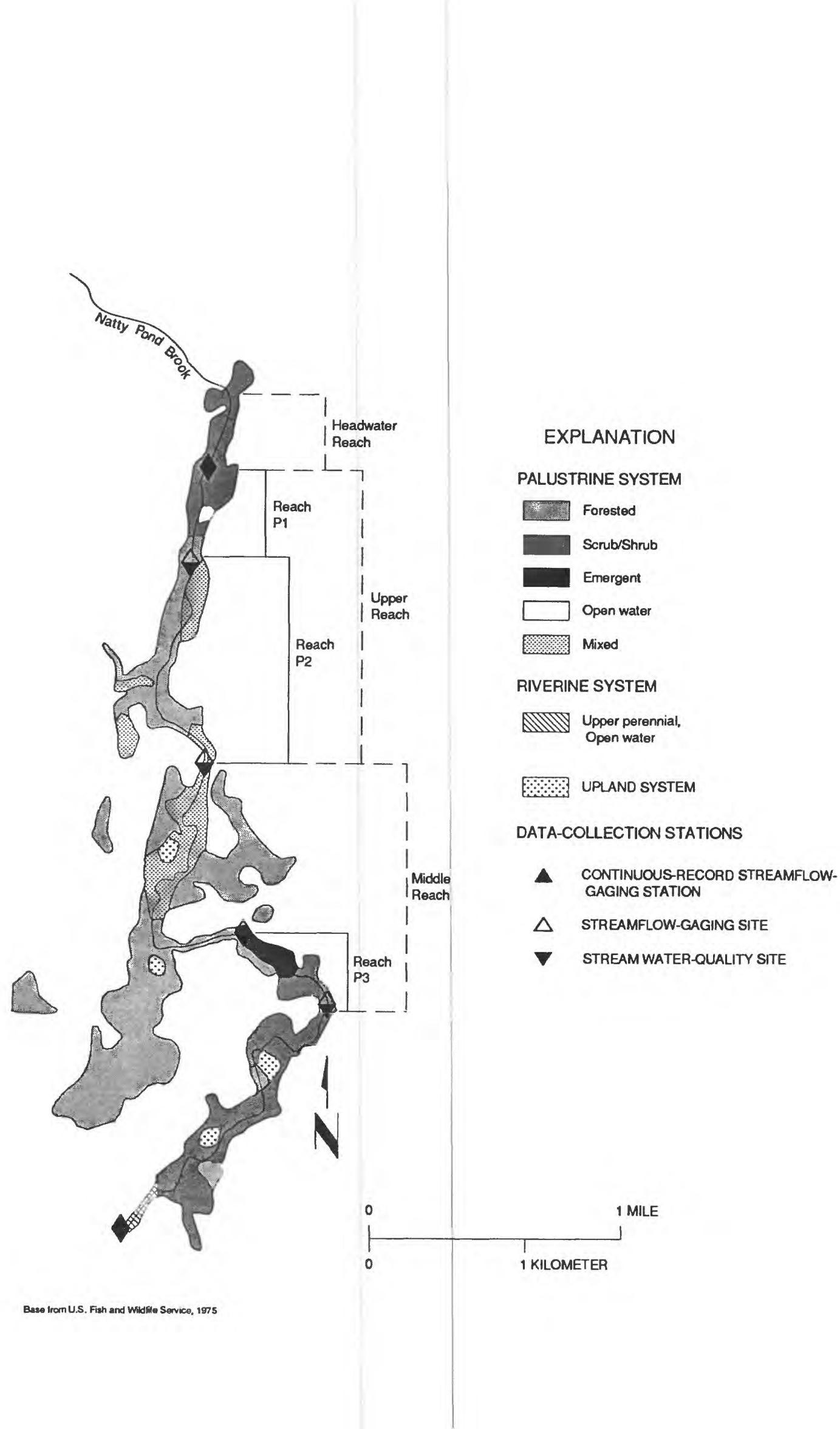

Figure 2.--Wetland-vegetation types and locations of stations used to measure dissolved-oxygen productivity in stream reaches of Natty Pond Brook, Massachusetts. 


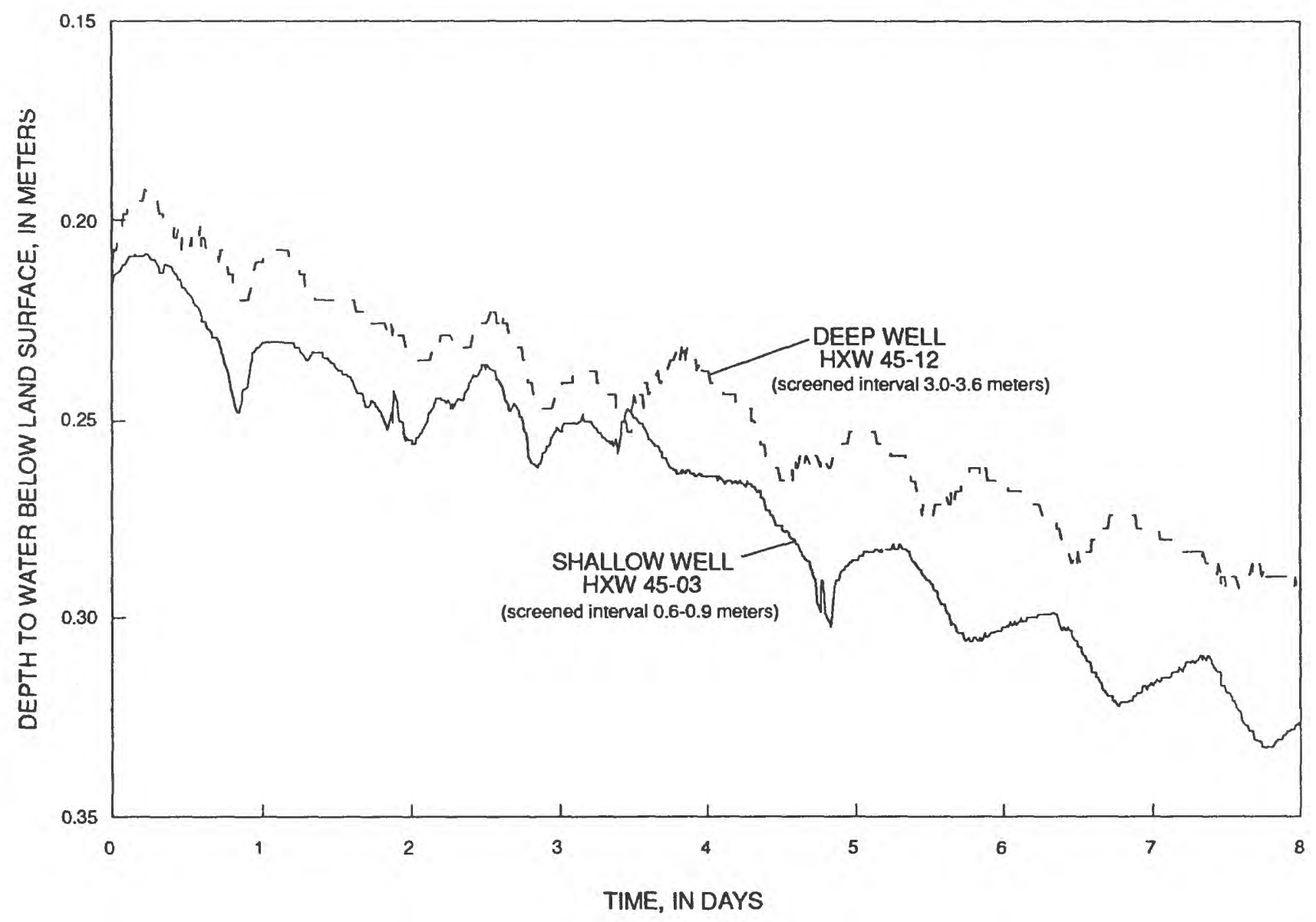

Figure 3.--Water levels in shallow and deep wells screened in peat deposits in Natty Pond Brook wetland, July 18-25, 1986.

\section{HYDROLOGY' OF THE STREAM-SIDE WETLAND SYSTEM}

The wetland's hydrologic system responds to water inputs and outputs. The system receives water directly from precipitation, from overland flow originating in adjacent uplands, from streamflow entering from the headwater reach, and from ground water. The system loses water by evapotranspiration and by streamflow exiting at the downstream end of the wetland. To gain an understanding of the hydrologic regime, changes in the water balance were recorded in response to these inputs and outputs.

\section{Water Balance}

Wetland water balances were determined for the period November 1984 through October 1986. The equation used to express the water balance of the wetland system is

$$
\mathrm{ULI}+\mathrm{P}=\mathrm{ET}+\mathrm{SRO} \pm \Delta \mathrm{ST} \pm \mathrm{R}
$$

All terms represent water volumes and are defined as--

ULI = upland surface- and ground-water inputs to wetland,

$\mathbf{P}=$ direct precipitation on stream and wetland,

ET = evapotranspiration from stream and wetland,

$\mathrm{SRO}=$ surface-runoff output at the downstream limit of wetland basin, 


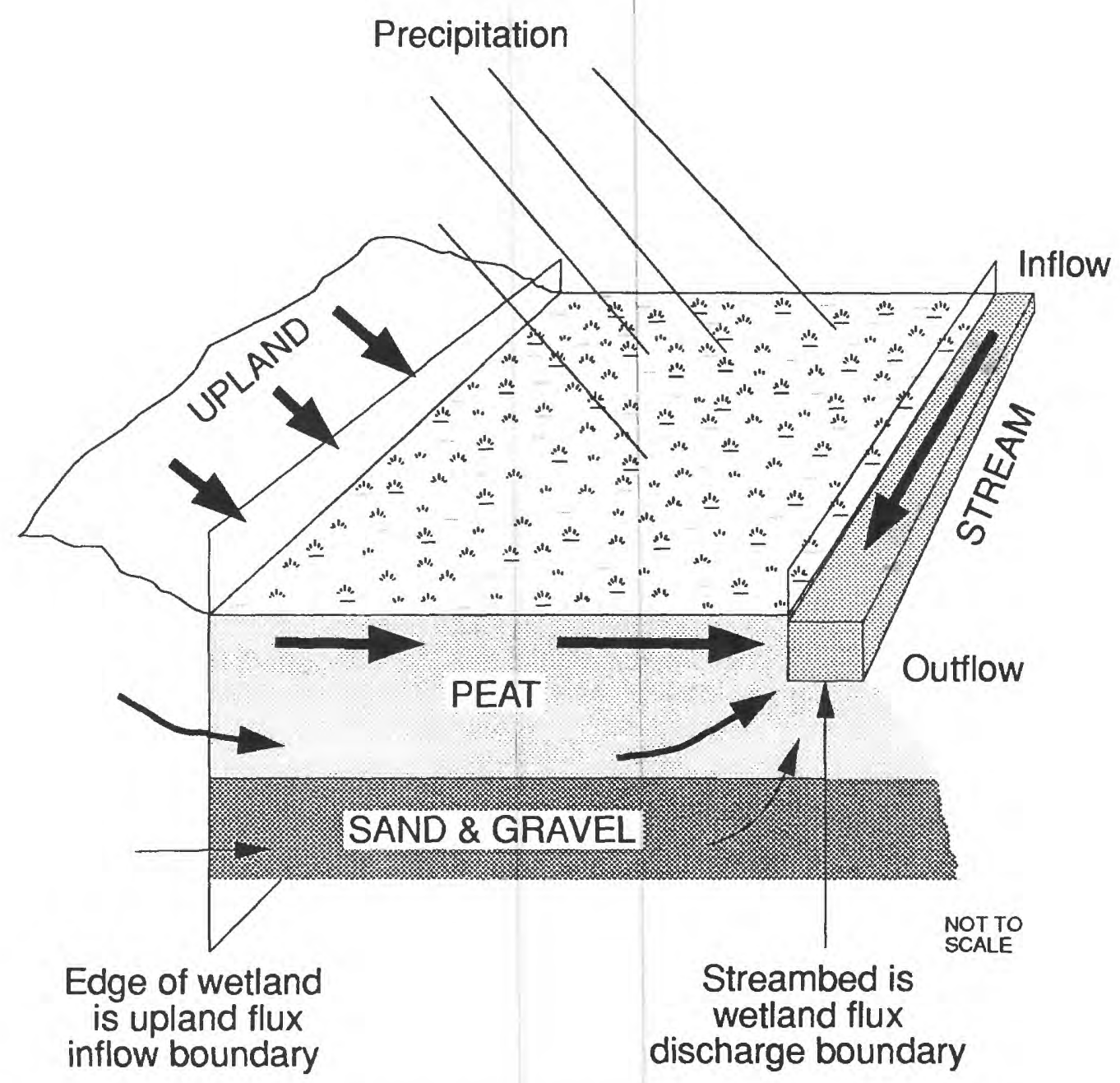

Figure 4.--Conceptual flow diagram through a wetland stream reach.

$$
\begin{aligned}
& \Delta S T=\begin{array}{l}
\text { changes in surface water and ground } \\
\text { water stored in wetland, and }
\end{array} \\
& R=\text { error residual. }
\end{aligned}
$$

Components of the water-balance equation are represented as inputs and outputs to the wetland system. Upland inputs (ULI) were both measured and estimated. Streamflow volume entering the wetland from the upland reach was calculated based on daily mean flow records at Q1 (fig. 1). Surface water and ground-water inputs from ungaged upland areas were estimated using the relation between runoff and drainage area defined by the upland reach (Q1). Precipitation input $(P)$ was recorded at the Barre Falls Dam rain gage located within $1.7 \mathrm{~km}$ of the wetland. Evapotran spiration (ET) was estimated from climatological data and water-retention factors of the wetland soil (Thornthwaite and Mather, 1957).
The volume of surface runoff (SRO) leaving the wetland basin was calculated from daily mean flow records at Q4 (fig. 1). Changes in the amount of surface and ground-water stored in the wetland $(\triangle S T)$ were determined from the net differences in surfaceand ground-water levels recorded over seasonal and annual periods and estimates of specific-yield of the peat. The error residual $(R)$ is the difference between the computed water-balance inputs and outputs.

Components of the water balances for the nearly 200-ha wetland for the 1985 and 1986 study years are as follows: Precipitation was $1,991,400 \mathrm{~m}^{3}(1,010$ $\mathrm{mm})$ and $2,011,300 \mathrm{~m}^{3}(1,020 \mathrm{~mm})$, upland surfaceand ground-water inputs were $4,068,200 \mathrm{~m}^{3}(2,060$ $\mathrm{mm}$ ) and $7,182,000 \mathrm{~m}^{3}(3,640 \mathrm{~mm})$, surface-water runoff was $4,772,800 \mathrm{~m}^{3}(2,420 \mathrm{~mm})$ and $7,706,100 \mathrm{~m}^{3}$ $(3,910 \mathrm{~mm})$, and evapotranspiration was $1,114,500 \mathrm{~m}^{3}$ 
$(570 \mathrm{~mm})$ and $1,092,900 \mathrm{~m}^{3}(550 \mathrm{~mm})$. Error residuals of $129,100 \mathrm{~m}^{3}(65 \mathrm{~mm})$ and $452,800 \mathrm{~m}^{3}(230 \mathrm{~mm})$ for the 2 years were within the limits of measurement but probably represent underestimates of evapotranspiration which were computed indirectly. Changes in storage were $+43,200 \mathrm{~m}^{3}(22 \mathrm{~mm})$ and $-58,500 \mathrm{~m}^{3}(-30$ $\mathrm{mm}$ ) in 1985 and 1986 , respectively.

Components of the water balance for the Natty Pond Brook wetland varied seasonally and annually as shown in table 2 and figures 5 and 6 . Spring streamflow represents a major part of the total annual streamflow (figs. 5 and 6). About 40 percent of the total annual volume of upland water input (ULI) occurred during March, April, and May (fig. 7) in 1985 and 1986. Similar seasonal variation occurred in the surface-runoff-output component (SRO) of the water balance (figs. 5 and 6). During the spring of both years, streamflow leaving the wetland accounted for about 35 percent of the total annual volumes (fig. 7). These large spring runoffs occurred because increases in air temperatures melted the snow and ice in the basin and because evapotranspiration rates were relatively low.

Streamflows during the summers were low. Forty percent of the annual precipitation volume in 1985 (fig. 7) and 34 percent in 1986 occurred during the summer, while only 22 and 19 percent of the annual streamflows occurred during the same periods. Lower summer runoff occurred because evapotranspiration rates were large and flow from storage was small. Twenty-four percent of the annual precipitation occurred in August 1985, but did not immediately increase the surface runoff from the wetland. Instead of running off, much of the precipitation evapotranspired. Some of the water went into storage, replenishing soil moisture and recharging ground-water, as indicated by the August increase in ground-water levels (fig. 8). This replenishment of ground-water storage accounted for increases in surface runoff in the following fall and winter (late 1985 and early 1986). In the fall of 1985 , ground-water levels remained higher than they had been prior to the August precipitation (fig. 9). Runoff volumes at Q4 increased by 50 to 60 percent through the first half of 1986 in response to monthly precipitation inputs (fig. $6)$.

The hydrologic response of the wetland demonstrated that the system's retention time is short term, measured in weeks to months. Water from high-flow periods was temporarily stored within the porous surface layer of the peat. Because of the high hydraulic conductivity of the surface peat layer, however, water cannot be stored for long periods (Boelter and Verry, 1977, p. 8). This phenomenon was evident during the summer when streamflow decreased in

Table 2.--Water balances for Natty Pond Brook wetland, November 1, 1984 through October 31, 1986

[All values in thousands of cubic meters. ULI, upland input; P, precipitation; ET, evapotranspiration; SRO, surface runoff output; $\Delta S T$, change in storage; $R$, error residual]

\begin{tabular}{|c|c|c|c|c|c|c|}
\hline Season & ULI & + & ET & SRO & $\Delta \mathrm{ST}$ & \pm \\
\hline \multicolumn{7}{|c|}{ Nov. 1, 1984 - Oct. 31, 1985} \\
\hline Winter & 585.4 & 298.6 & 0.0 & 885.8 & 62.3 & -64.1 \\
\hline Spring & 1607.7 & 440.6 & 216.6 & 1643.8 & 27.3 & 160.6 \\
\hline Summer & 969.2 & 792.1 & 647.8 & 1030.4 & -62.4 & 145.5 \\
\hline Fall & 905.9 & 460.1 & 250.1 & 1212.8 & 16.0 & -112.9 \\
\hline Total & 4068.2 & 1991.4 & 1114.5 & 4772.8 & 43.2 & 129.1 \\
\hline \multicolumn{7}{|c|}{ Nov. 1, 1985 - Oct. 31, 1986} \\
\hline Winter & 2059.0 & 458.1 & .0 & 2246.7 & .0 & 270.4 \\
\hline Spring & 2758.3 & 394.6 & 256.0 & 2722.1 & -46.8 & 221.6 \\
\hline Summer & 1381.9 & 682.6 & 618.3 & 1483.3 & -66.3 & 29.2 \\
\hline Fall & 982.8 & 476.0 & 218.6 & 1254.0 & 54.6 & -68.4 \\
\hline Total & 7182.0 & 2011.3 & 1092.9 & 7706.1 & -58.5 & 452.8 \\
\hline
\end{tabular}




\section{SEASONAL}

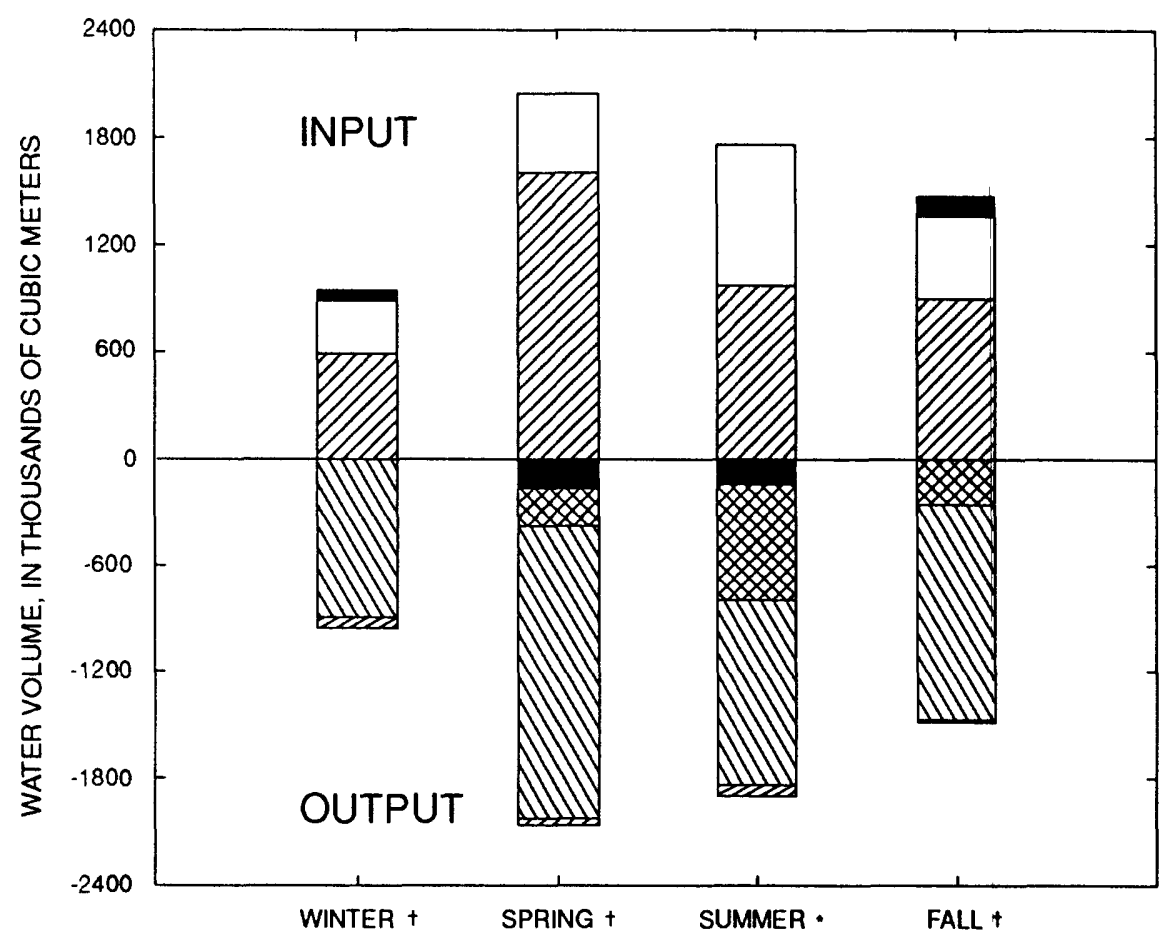

ANNUAL

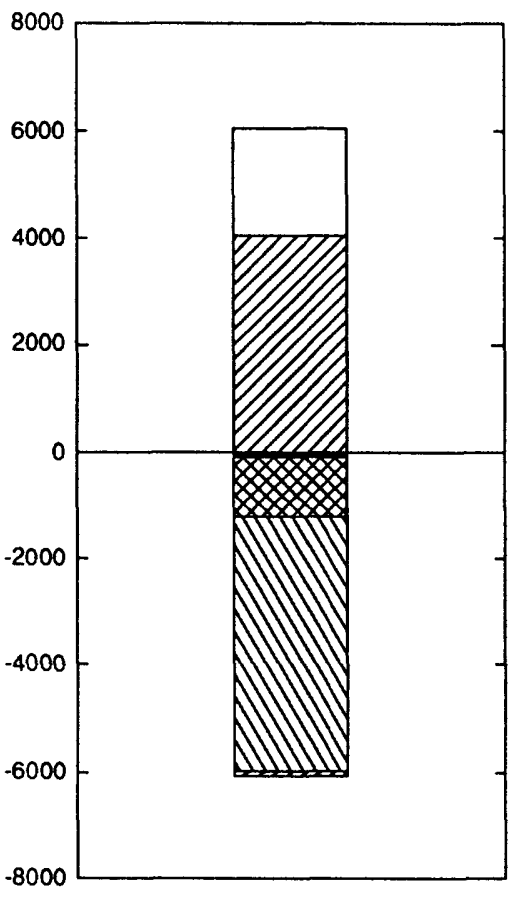

+ INCREASE IN STORAGE ADDED TO OUTPUT TOTAL - DECREASE IN STORAGE SUBTRACTED FROM
OUTPUT TOTAL

\section{EXPLANATION}

7 CHANGES IN STORAGE B EVAPOTRANSPIRATION OUTPUT $\checkmark$ SURFACE WATER OUTPUT ERROR RESIDUAL PRECIPITATION INPUT UPLAND INPUT

Figure 5.--Seasonal distribution of water-balance components, 1985.

response to continued drainage from storage and large seasonal evapotranspiration rates (fig. 7). On the basis of streamflow and ground-water-level data, streamflow decreased and water was removed from storage in the summer when evapotranspiration rates were high. During the early spring and late fall, when evapotranspiration rates were low, a gain of flow from the wetland was recorded (fig. 10).

Stream-water quality is controlled, in part, by seasonal changes in the hydrologic conditions in a wetland. During periods of increasing high flow, for example, water enters the wetland along the upland flux inflow boundary (fig. 4) and displaces water containing high concentrations of dissolved organic substances and other constituents from the peat. The displaced water flows to the stream, increasing constituent loads in the stream. During low-flow periods, discharge from peat deposits decreases, and, consequently, the contribution of constituent loads to the stream also decreases. Seasonal differences in constituent loading may also be caused by changes in biological processes. For example, during the growing season, high nutrient loads that are transported to the stream may be substantially reduced by plant uptake from the stream water.

\section{Measurement Precision}

Uncertainties are inherent in the measurements of hydrologic and physical characteristics of any environmental system. In an effort to quantify error within the water balance, estimates of measurement precision were made for each method of hydrologic 


\section{SEASONAL}

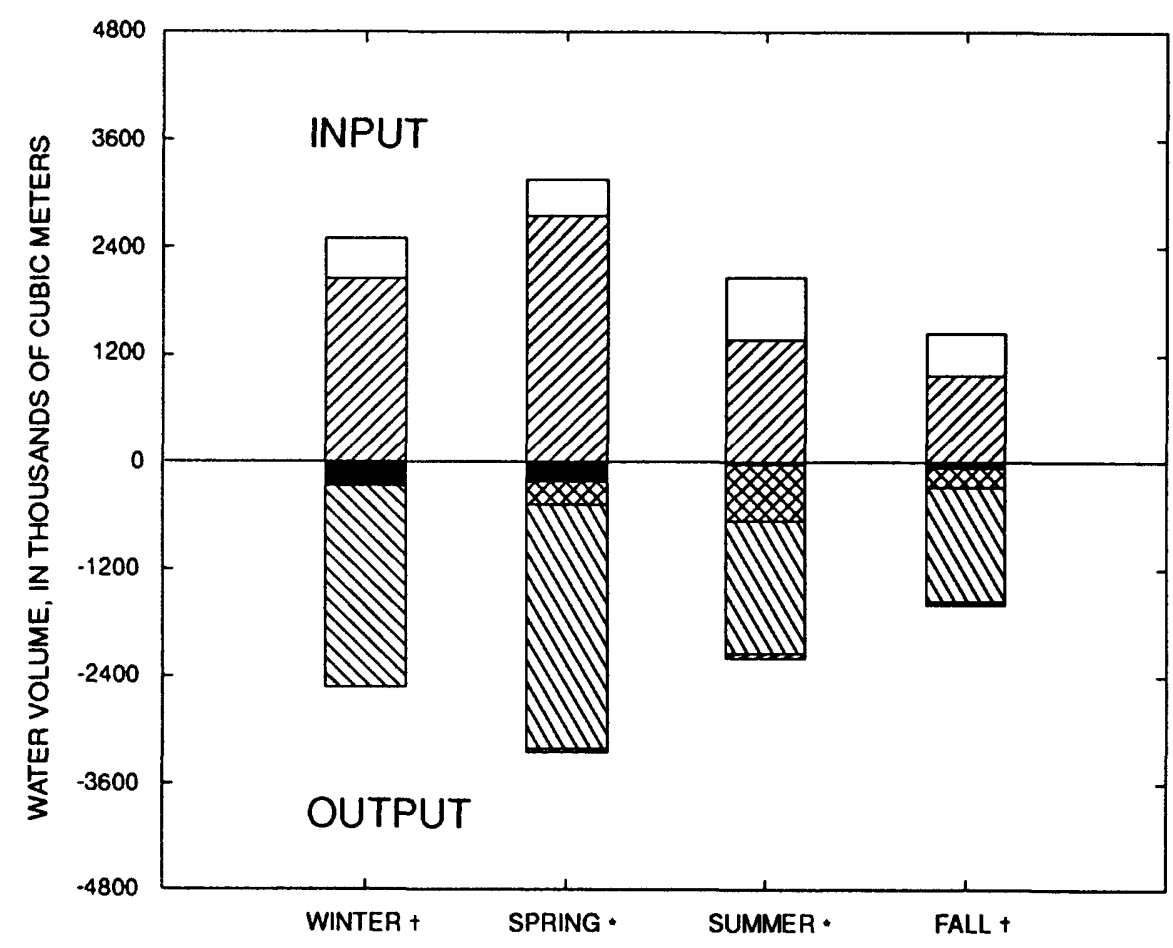

ANNUAL

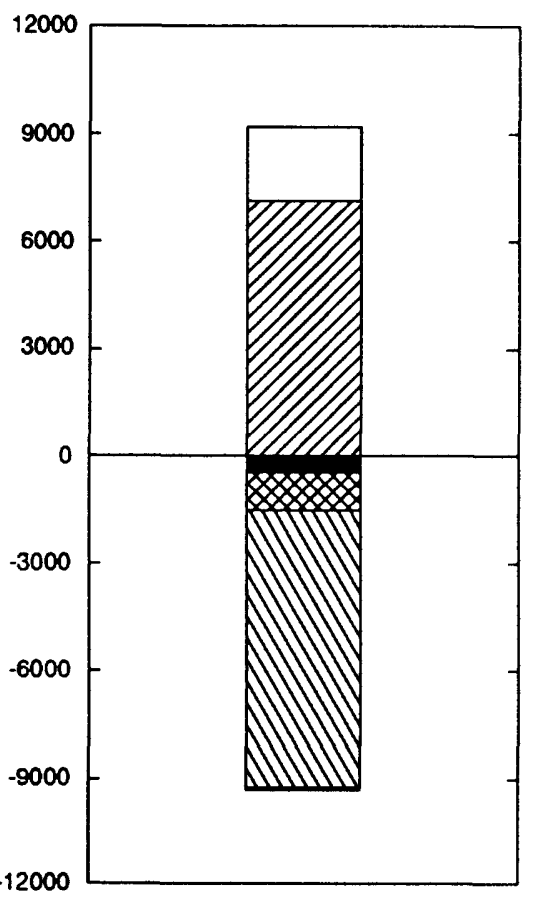

+ INCREASE IN STORAGE AD́oED TO OUTPUT TOTAL - DECREASE in STORAge SUBTRActed FRom OUTPUT TOTAL

\section{EXPLANATION}

Q CHANGES IN STORAGE 89 EVAPOTRANSPIRATION OUTPUT

$\triangle$ SURFACE WATER OUTPUT SURFACE WATER PRECIPITATION INPUT UPLAND INPUT

Figure 6.--Seasonal distribution of water-balance components, 1986.

data collection, and a percent error was assigned to each water-balance component. These estimates were based on error levels reported by Winter (1981, p. 109), who computed water balances of lakes in New England. Measurement error was estimated to be 20 percent for upland water input, 10 percent for precipitation, 10 percent for surface runoff, 15 percent for evapotranspiration, and $\mathbf{5 0}$ percent for changes in ground- and surface-water storage. However, total error in the water balance is not likely to be equivalent to the sum of all component errors. More likely, some of the errors are positive and some negative relative to the "true" value. Therefore, errors would tend to balance out.

The difference between inputs and outputs $(R)$ of the annual water balances (figs. 5 and 6) was 2 percent for 1985 and 5 percent for 1986 . Differences in sea- sonal water balances were less than 10 percent of the input or output, except for winter 1986, when the difference was 11 percent. These relatively small differences between the inputs and outputs of the water balances are consistent with the evapotranspiration estimates that were computed for the wetland by the method of Thornthwaite and Mather (1957).

\section{EFFECTS OF THE WETLAND ON THE QUALITY OF NATTY POND BROOK}

Samples of water entering and leaving the wetland were collected for quality analyses approximately monthly during low- to medium-flow conditions. During periods when streamflow in- 

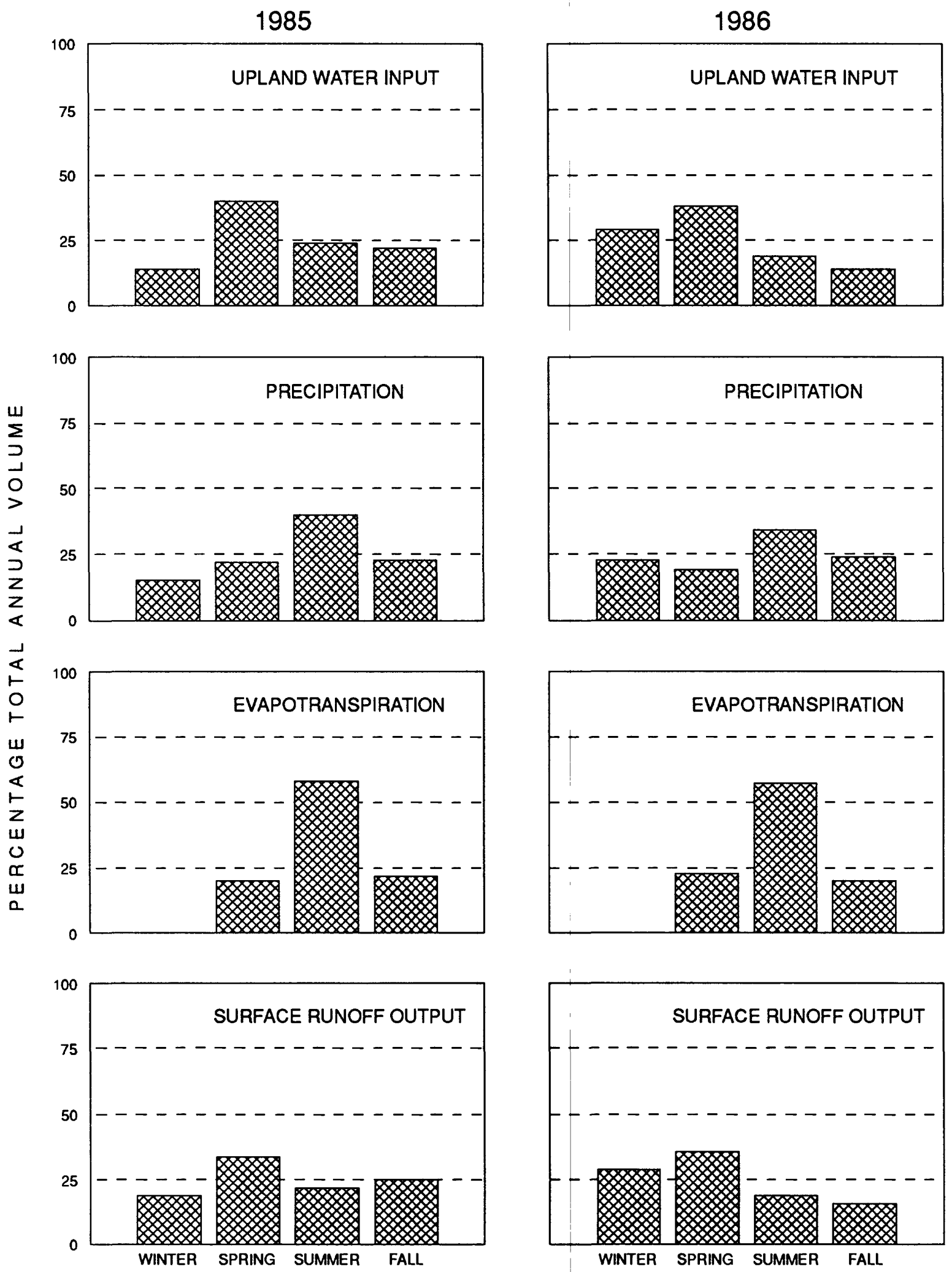

Figure 7.--Seasonal distribution of water-balance components, as percentages of total annual water volume, Natty Pond Brook, Massachusetts, 1985 and 1986. 

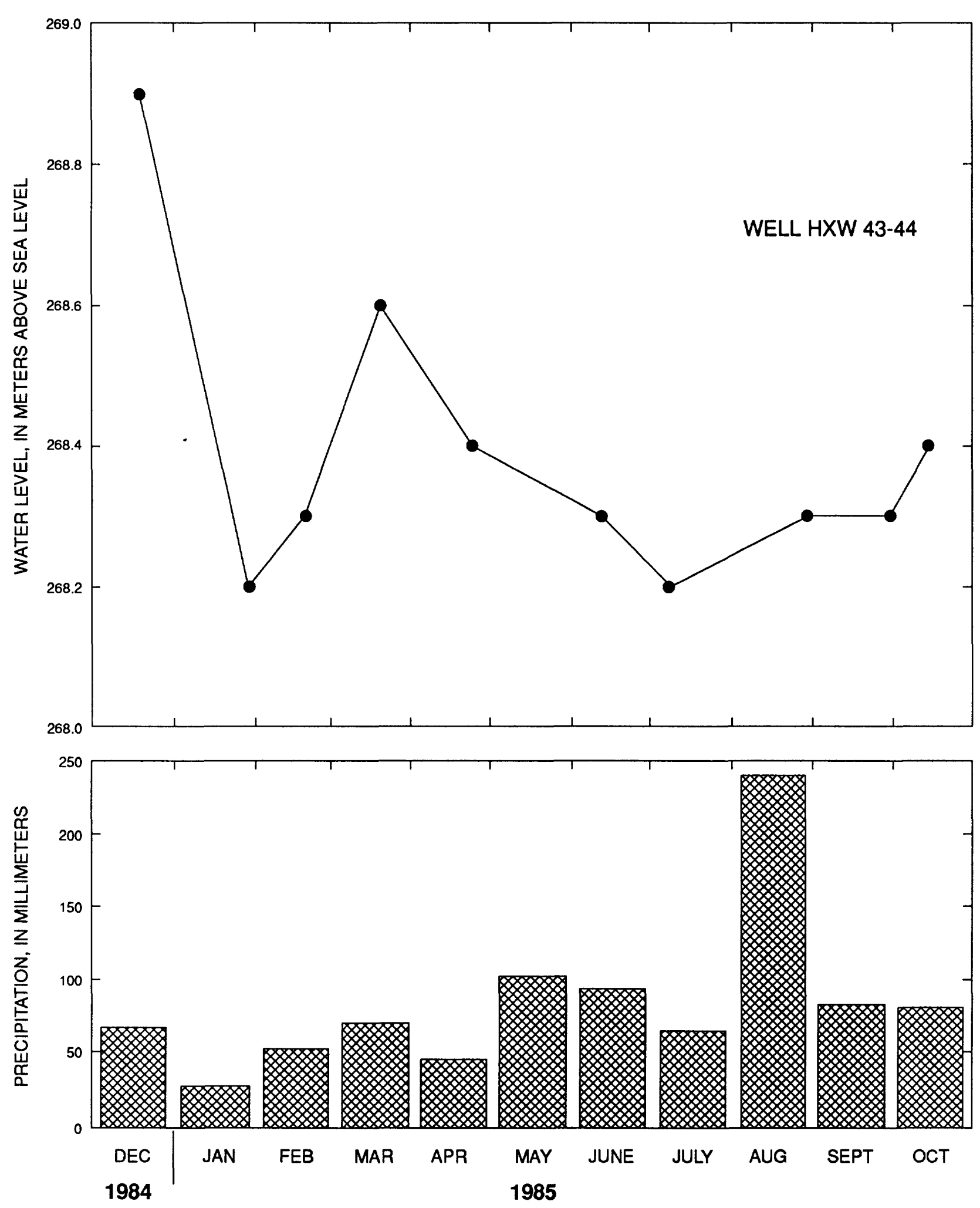

Figure 8.--Precipitation near, and water levels in, a well in the wetland, December 1984 through October 1985. 

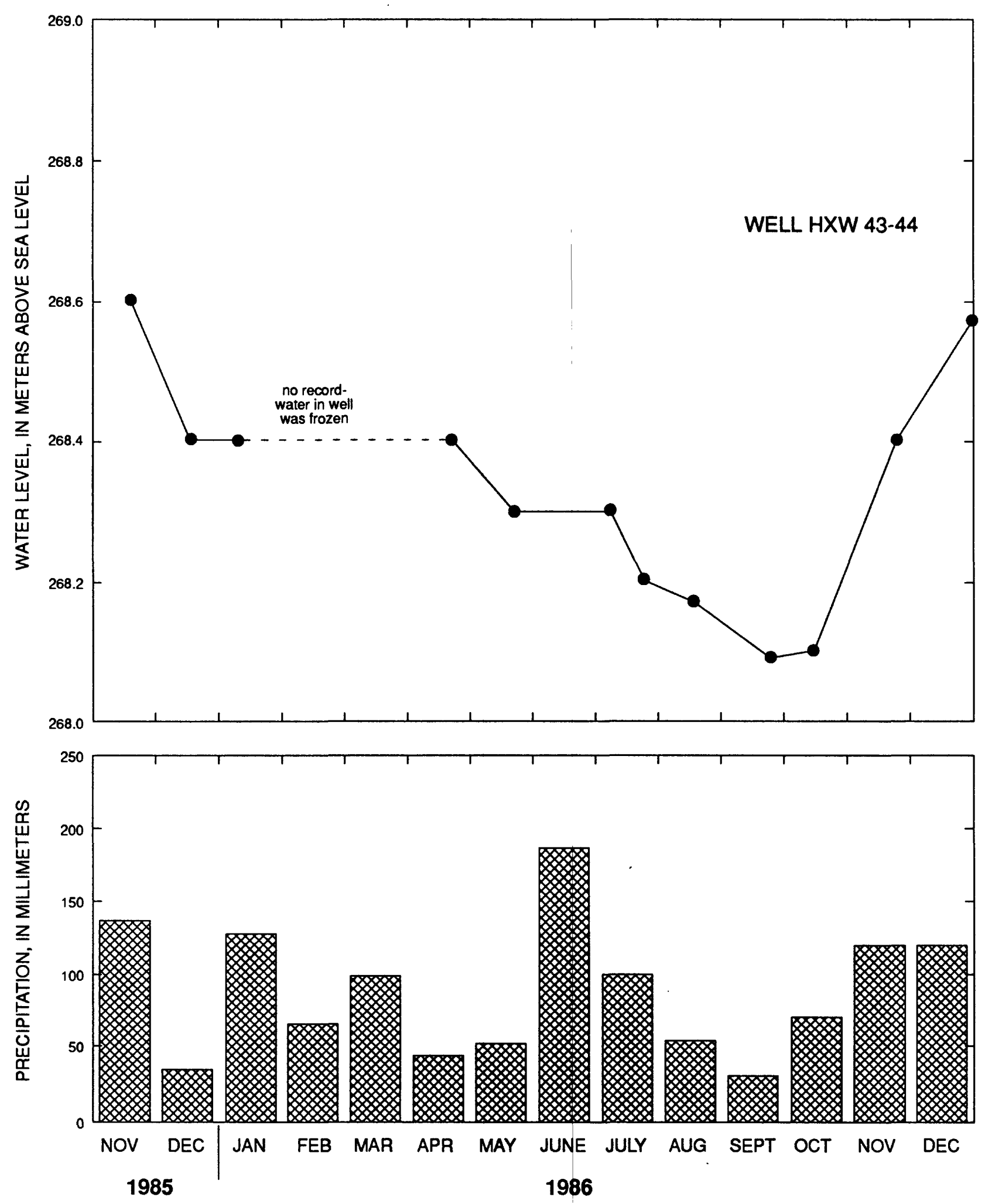

Figure 9.--Precipitation near, and water levels in, a well in the wetland, November 1985 through December 1986. 


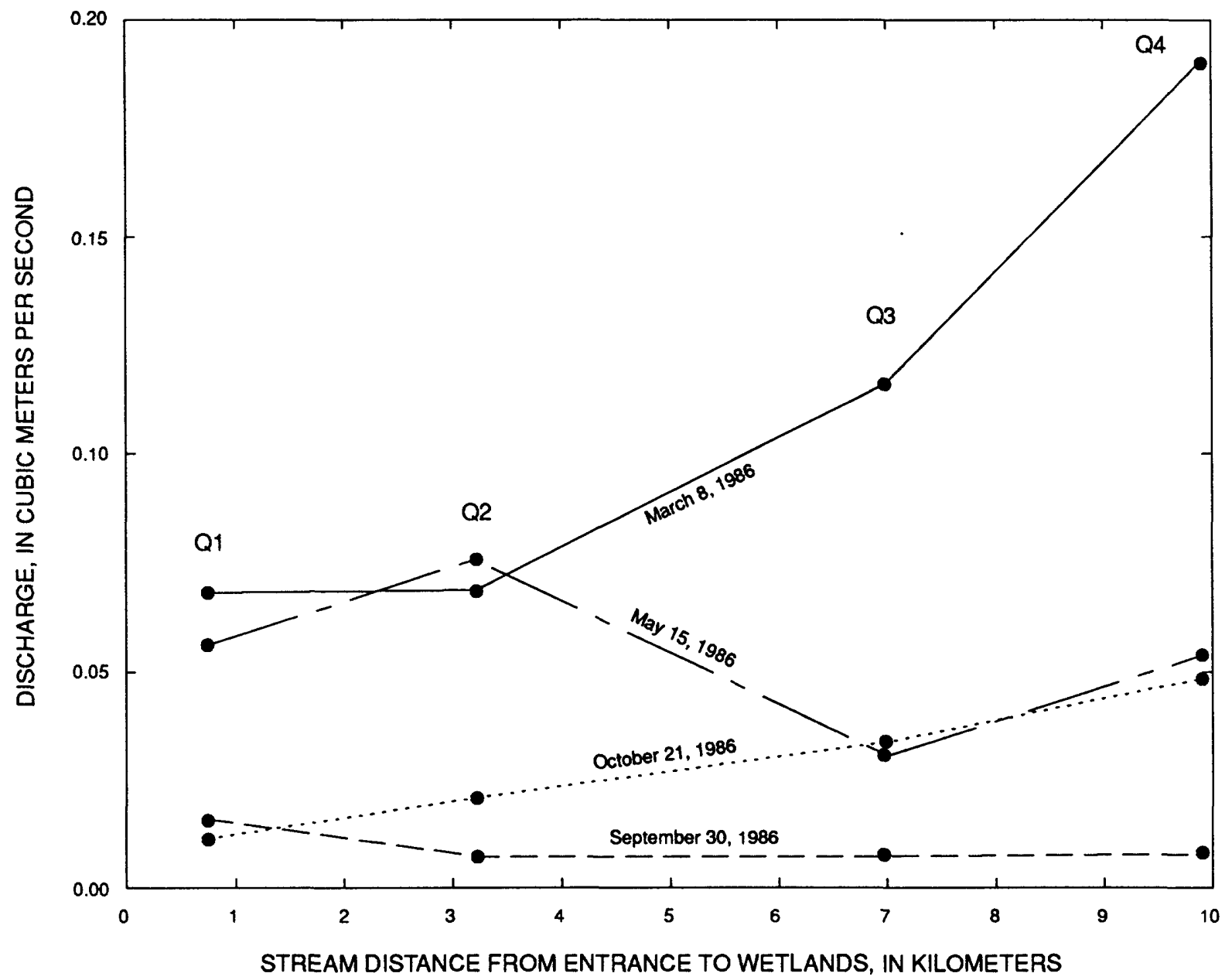

Figure 10.-Discharge measured during four seepage runs at numbered water-quality sites on Natty Pond Brook, Massachusetts.

creased in response to rainfall or snowmelt, samples were collected more frequently, and were collected from two additional stations within the wetland. A summary of the water-quality data collected during the study is given in table 3. Although diurnal fluctuations of DO were detected and described, sufficient diurnal observations were not collected for detailed determination of chemical loads and discharges.

The basin was divided into four subbasins (fig. 1), and changes in chemical loads were determined through each subbasin. Loads within the four different stream reaches were calculated from constituent concentrations and daily mean discharge at $\mathrm{Q} 1, \mathrm{Q} 2$, Q3, and Q4 (fig. 11). When concentrations were less than the detection limit, a value of one half the detection limit was assumed in the load calculations. Discharges at Q2 and Q3 were based partly on stage-discharge relations at each site and partly on rating curve extrapolation (Rantz, 1982, p. 337). This technique extrapolates discharge data at a partial-record station based on measured runoff rates adjusted for drainage area.

Daily loads in kilograms per day for each waterquality constituent at each site were computed by applying regression equations developed from 9-16 data sets of measurements of load (mass/time) and streamflow (volume/time). Regression equations were computed using a log transformation of the data and the method of least squares. The standard error of a regression equation in which load (as calculated above) is related to streamflow is equal to that of an equation of instantaneous concentration data (mass/volume) versus continuous streamflow (E.J. Gilroy, U.S. Geological Survey, written commun., 1987). The equations of load versus flow were used to compute daily loads for periods between sampling 
Table 3.--Maximum, median, and minimum values of chemical concentrations and properties, by reach, from Natty Pond Brook, Massachusetts, from November 1, 1984 through October 31, 1986

[Concentration in milligrams per liter except as noted; Pt-Co units, platinum-cobalt units; $\mu \mathrm{S} / \mathrm{cm}$, microsiemens per centimeter at 25 degrees Celsius; $\mu \mathrm{g} / \mathrm{L}$, micrograms per liter; --, no data; <, less than]

\begin{tabular}{|c|c|c|c|c|c|}
\hline $\begin{array}{l}\text { Constituent } \\
\text { or property }\end{array}$ & $\begin{array}{l}\text { Type of } \\
\text { statistic }\end{array}$ & $\begin{array}{l}\text { Q1 } \\
\text { Headwater } \\
\text { reach }\end{array}$ & $\begin{array}{l}\text { Q2 } \\
\text { Upper } \\
\text { reach }\end{array}$ & $\begin{array}{l}\text { Q3 } \\
\text { Middle } \\
\text { reach }\end{array}$ & $\begin{array}{l}\text { Q4 } \\
\text { Lower } \\
\text { reach }\end{array}$ \\
\hline $\begin{array}{l}\text { Dissolved ammonium } \\
\text { nitrogen, as } \mathrm{N}\end{array}$ & $\begin{array}{l}\text { Maximum } \\
\text { Median } \\
\text { Minimum } \\
\text { No. of analyses }\end{array}$ & $\begin{array}{r}0.04 \\
.02 \\
<.01 \\
16\end{array}$ & $\begin{array}{r}0.09 \\
.06 \\
<.01 \\
10\end{array}$ & $\begin{array}{l}1.1 \\
.05 \\
<.01 \\
10\end{array}$ & $\begin{array}{r}0.82 \\
.06 \\
<.01 \\
16\end{array}$ \\
\hline $\begin{array}{l}\text { Dissolved nitrite } \\
\text { nitrogen, as N }\end{array}$ & $\begin{array}{l}\text { Maximum } \\
\text { Median } \\
\text { Minimum } \\
\text { No. of analyses }\end{array}$ & $\begin{array}{l}.02 \\
<.01 \\
<.01 \\
16\end{array}$ & $\begin{array}{l}.02 \\
<.01 \\
<.01 \\
10\end{array}$ & $\begin{array}{l}.02 \\
<.01 \\
<.01 \\
10\end{array}$ & $\begin{array}{l}\quad .07 \\
<.01 \\
<.01 \\
16\end{array}$ \\
\hline $\begin{array}{l}\text { Dissolved nitrite- } \\
\text { plus-nitrate } \\
\text { nitrogen, as N }\end{array}$ & $\begin{array}{l}\text { Maximum } \\
\text { Median } \\
\text { Minimum } \\
\text { No. of analyses }\end{array}$ & $\begin{array}{r}.38 \\
<.10 \\
<.10 \\
16\end{array}$ & $\begin{array}{r}.31 \\
.10 \\
<.10 \\
10\end{array}$ & $\begin{array}{r}.35 \\
<.10 \\
<.10 \\
10\end{array}$ & $\begin{array}{r}.49 \\
.11 \\
<.10 \\
16\end{array}$ \\
\hline $\begin{array}{l}\text { Dissolved hydro- } \\
\text { lyzable-plus- } \\
\text { orthophosphate } \\
\text { phosphorus, as P }\end{array}$ & $\begin{array}{l}\text { Maximum } \\
\text { Median } \\
\text { Minimum } \\
\text { No. of analyses }\end{array}$ & $\begin{array}{l}.10 \\
<.01 \\
<.01 \\
16\end{array}$ & $\begin{array}{l}.01 \\
<.01 \\
<.01 \\
10\end{array}$ & $\begin{array}{l}.22 \\
<.01 \\
<.01 \\
10\end{array}$ & $\begin{array}{r}.09 \\
.03 \\
<.01 \\
16\end{array}$ \\
\hline $\begin{array}{l}\text { Dissolved } \\
\text { orthophosphate } \\
\text { phosphorus, as P }\end{array}$ & $\begin{array}{l}\text { Maximum } \\
\text { Median } \\
\text { Minimum } \\
\text { No. of analyses }\end{array}$ & $\begin{array}{l}.04 \\
<.01 \\
<.01 \\
16\end{array}$ & $\begin{array}{l}<.01 \\
<.01 \\
<.01 \\
10\end{array}$ & $\begin{array}{l}.23 \\
<.01 \\
<.01 \\
10\end{array}$ & $\begin{array}{r}.10 \\
.02 \\
<.01 \\
16\end{array}$ \\
\hline $\begin{array}{l}\text { Dissolved organic } \\
\text { carbon }\end{array}$ & $\begin{array}{l}\text { Maximum } \\
\text { Median } \\
\text { Minimum } \\
\text { No. of analyses }\end{array}$ & $\begin{array}{c}8.7 \\
4.3 \\
1.3 \\
16\end{array}$ & $\begin{array}{r}6.6 \\
4.9 \\
2.7 \\
10\end{array}$ & $\begin{array}{l}15 . \\
11 . \\
6.0 \\
10\end{array}$ & $\begin{array}{l}22 . \\
12 . \\
6.3 \\
16\end{array}$ \\
\hline $\begin{array}{l}\text { Suspended organic } \\
\text { carbon }\end{array}$ & $\begin{array}{l}\text { Maximum } \\
\text { Median } \\
\text { Minimum } \\
\text { No. of analyses }\end{array}$ & $\begin{array}{r}.7 \\
.4 \\
.2 \\
11\end{array}$ & $\begin{array}{l}.9 \\
.4 \\
.2 \\
6\end{array}$ & $\begin{array}{l}2.9 \\
.6 \\
.4 \\
6\end{array}$ & $\begin{array}{r}1.8 \\
.4 \\
.1 \\
11\end{array}$ \\
\hline Dissolved sulfate & $\begin{array}{l}\text { Maximum } \\
\text { Median } \\
\text { Minimum } \\
\text { No. of analyses }\end{array}$ & $\begin{array}{c}16.0 \\
7.3 \\
3.1 \\
16\end{array}$ & $\begin{array}{r}13.0 \\
8.8 \\
6.5 \\
10\end{array}$ & $\begin{array}{r}14.0 \\
9.5 \\
5.5 \\
10\end{array}$ & $\begin{array}{c}16.0 \\
10.5 \\
5.0 \\
16\end{array}$ \\
\hline $\begin{array}{l}\text { Dissolved } \\
\text { oxygen }\end{array}$ & $\begin{array}{l}\text { Maximum } \\
\text { Median } \\
\text { Minimum } \\
\text { No. of analyses }\end{array}$ & $\begin{array}{c}13.2 \\
10.6 \\
6.8 \\
15\end{array}$ & $\begin{array}{c}14.0 \\
11.9 \\
9.0 \\
9\end{array}$ & $\begin{array}{c}11.3 \\
10.0 \\
4.7 \\
9\end{array}$ & $\begin{array}{r}12.2 \\
9.8 \\
5.5 \\
15\end{array}$ \\
\hline $\begin{array}{l}\text { Diurnal } \\
\text { dissolved } \\
\text { oxygen }\end{array}$ & $\begin{array}{l}\text { Maximum } \\
\text { Median } \\
\text { Minimum } \\
\text { No. of analyses }\end{array}$ & $\begin{array}{l}8.5 \\
8.1 \\
7.6 \\
25\end{array}$ & $\begin{array}{c}10.3 \\
9.8 \\
9.3 \\
25\end{array}$ & $\begin{array}{l}3.1 \\
2.8 \\
2.7 \\
25\end{array}$ & $\begin{array}{l}-- \\
-- \\
-- \\
--\end{array}$ \\
\hline
\end{tabular}


Table 3.--Maximum, median, and minimum values of chemical concentrations and properties, by reach, from Natty Pond Brook, Massachusetts, from November 1, 1984 through October 31, 1986--Continued

\begin{tabular}{|c|c|c|c|c|c|}
\hline $\begin{array}{l}\text { Constituent } \\
\text { or property }\end{array}$ & $\begin{array}{l}\text { Type of } \\
\text { statistic }\end{array}$ & $\begin{array}{l}\text { Q1 } \\
\text { Headwater } \\
\text { reach }\end{array}$ & $\begin{array}{l}\text { Q2 } \\
\text { Upper } \\
\text { reach }\end{array}$ & $\begin{array}{l}\text { Q3 } \\
\text { Middle } \\
\text { reach }\end{array}$ & $\begin{array}{l}\text { Q4 } \\
\text { Lower } \\
\text { reach }\end{array}$ \\
\hline $\begin{array}{l}\text { Color } \\
\text { (Pt-Co units) }\end{array}$ & $\begin{array}{l}\text { Maximum } \\
\text { Median } \\
\text { Minimum } \\
\text { No. of analyses }\end{array}$ & $\begin{array}{r}55 \\
20 \\
7 \\
16\end{array}$ & $\begin{array}{l}40 \\
30 \\
10 \\
10\end{array}$ & $\begin{array}{r}450 \\
90 \\
40 \\
10\end{array}$ & $\begin{array}{r}500 \\
130 \\
40 \\
15\end{array}$ \\
\hline $\mathrm{pH}_{\text {(pH units) }}$ & $\begin{array}{l}\text { Maximum } \\
\text { Median } \\
\text { Minimum } \\
\text { No. of analyses }\end{array}$ & $\begin{array}{c}6.02 \\
5.66 \\
5.05 \\
16\end{array}$ & $\begin{array}{c}6.56 \\
6.26 \\
5.34 \\
10\end{array}$ & $\begin{array}{c}6.14 \\
5.78 \\
5.26 \\
10\end{array}$ & $\begin{array}{c}6.30 \\
5.86 \\
5.07 \\
16\end{array}$ \\
\hline $\begin{array}{l}\text { Alkalinity } \\
\text { (as calcium } \\
\text { carbonate) }\end{array}$ & $\begin{array}{l}\text { Maximum } \\
\text { Median } \\
\text { Minimum } \\
\text { No. of analyses }\end{array}$ & $\begin{array}{r}4.1 \\
1.2 \\
.2 \\
16\end{array}$ & $\begin{array}{r}3.9 \\
2.5 \\
.4 \\
10^{.4}\end{array}$ & $\begin{array}{r}8.2 \\
2.0 \\
.6 \\
10\end{array}$ & $\begin{array}{r}6.6 \\
2.2 \\
16\end{array}$ \\
\hline $\begin{array}{l}\text { Specific } \\
\text { conductance } \\
(\mu \mathrm{S} / \mathrm{cm})\end{array}$ & $\begin{array}{l}\text { Maximum } \\
\text { Median } \\
\text { Minimum } \\
\text { No. of analyses }\end{array}$ & $\begin{array}{l}45 \\
36 \\
27 \\
16\end{array}$ & $\begin{array}{l}50 \\
44 \\
37 \\
10\end{array}$ & $\begin{array}{l}67 \\
44 \\
40 \\
10\end{array}$ & $\begin{array}{l}59 \\
48 \\
42 \\
15\end{array}$ \\
\hline $\begin{array}{l}\text { Dissolved iron } \\
(\mu \mathrm{g} / \mathrm{L})\end{array}$ & $\begin{array}{l}\text { Maximum } \\
\text { Median } \\
\text { Minimum } \\
\text { No. of analyses }\end{array}$ & $\begin{array}{r}240 \\
120 \\
50 \\
16\end{array}$ & $\begin{array}{r}430 \\
260 \\
200 \\
10\end{array}$ & $\begin{array}{r}2,700 \\
790 \\
270 \\
10\end{array}$ & $\begin{array}{r}2,000 \\
1010 \\
220 \\
16\end{array}$ \\
\hline $\begin{array}{r}\text { Total iron } \\
(\mu \mathrm{g} / \mathrm{L})\end{array}$ & $\begin{array}{l}\text { Maximum } \\
\text { Median } \\
\text { Minimum } \\
\text { No. of analyses }\end{array}$ & $\begin{array}{r}490 \\
200 \\
60 \\
16\end{array}$ & $\begin{array}{r}1,700 \\
720 \\
310 \\
10\end{array}$ & $\begin{array}{r}3,500 \\
1100 \\
310 \\
10\end{array}$ & $\begin{array}{r}3,300 \\
1400 \\
230 \\
16\end{array}$ \\
\hline $\begin{array}{l}\text { Dissolved } \\
\text { aluminum } \\
(\mu \mathrm{g} / \mathrm{L})\end{array}$ & $\begin{array}{l}\text { Maximum } \\
\text { Median } \\
\text { Minimum } \\
\text { No. of analyses }\end{array}$ & $\begin{array}{r}210 \\
115 \\
60 \\
16\end{array}$ & $\begin{array}{r}120 \\
85 \\
40 \\
10\end{array}$ & $\begin{array}{r}200 \\
120 \\
60 \\
10\end{array}$ & $\begin{array}{r}270 \\
130 \\
70 \\
16\end{array}$ \\
\hline
\end{tabular}

1 Data not used in load calculations 
events. Computed loads were corrected for log-distribution-bias using the technique described by Duan (1983). An alternate approach for daily load calculation using assignment of concentration for time periods founded by mid points between sampling dates was considered cumbersome and less representative.

The effects of the wetland on stream-water quality during different flow and seasonal conditions were described by separating the chemical discharges for each subreach into eight time periods (four seasons each year, for 2 years) described in table 4 . The length of each period is nearly equal (90-92 days), enabling direct comparison of stream chemical discharges from season to season. General hydrologic characteristics and condition of vegetation are given for each season in table 4. Because data collection began in November 1984, the fall seasonal period included November 1984 and September through October 1985. The fall seasonal period of 1986 included November of 1985 and September through October of 1986.

The chemical loads contributed by wetland areas within each of three subbasins were obtained by subtracting the incoming loads from upstream basins and from upland areas from the outflowing loads. Chemical loads per unit area computed for the gaged upland reach (Q1) were applied to all upland areas contributing to the other reaches.

Chemical changes that occur as ground-water passes through slowly decomposing organic material are shown by comparing the quality of water collected from wells in sand-and-gravel with that collected from the peat deposits (table 5). Concentrations of organic carbon, nitrogen, and phosphorous were higher in peat than in sand and gravel. However, concentrations of chlorides and values of specific conductance in peat were about half of those in sand and gravel. These data indicate that most of the peat water is derived from precipitation and upland inflow and that peat water gains organic acids and nutrients released through peat mineralization. The quality of water discharging to the stream is governed more by the constituents originating from wetland peat deposits than by constituents originating from sand and gravel.

Comparisons of direct precipitation loads to wetland-derived loads were made to assess whether net changes in chemical discharges along wetland reaches were mainly the result of precipitation inputs or the result of processes occurring in the wetland. Precipitation loads (table 6) were computed for each wetland subbasin on the basis of data reported by other re- searchers (R. L. Rittmaster, U.S. Geological Survey, written commun., 1986) and (Mitsch and Gosselink, 1986 , p. 107).

Stream-water travel times in Natty Pond Brook were determined, because the residence time of water in a wetland stream seemed to have a strong effect on the concentrations of nutrients and other water-quality constituents in the stream. Six data-collection sites on the stream (fig. 12) were studied during lowflow conditions (Sept. 1984, April 1985, May 1985, Aug. 1985, and June 1986) and centroid travel times between sites were computed (table 7) using the procedures described by Hubbard and others (1982). Travel time of the center-of-mass (centroid) of the dye cloud was related to mean stream discharge. From this relation and reach length, centroid travel times were calculated for the four stream reaches of Natty Pond Brook (fig. 13). The mean velocity for each reach of Natty Pond Brook is estimated from this relation, to be equal to the inverse of the slope of the relation line. These data are summarized in table 8 . This analysis is based on measurements made during low flow and extreme low-flow conditions when the longest travel times were expected to occur. Therefore, the travel times represent maximum residence times of water through the wetland system. As follows, these are also the maximum time periods required for a soluble chemical constituent to move through the four reaches of Natty Pond Brook.

The wetland and upland contributions to streamflow for each reach, by season, are shown in figure 14. The wetland-derived flow volumes were computed as the difference between the measured station flow (flow outputs) and the estimated flow from upland areas within the subbasin (flow inputs). Therefore, wetland-derived flow volumes represent the net change in flow between stations. It is significant to note that streamflow decreased through the middle wetland reach during the spring and summer of both years. During the spring of 1986, the wetland, as a whole, contributed virtually no gain to streamflow. These effects are attributed to a high rate of evapotranspiration from the wetland during the growing season.

The seasonal changes in constituent loading for each of the four subbasins are shown in figures 15-26. These data are summarized in table 9 , indicating net retention (-) or net release $(+)$ of a water-quality constituent along each reach. 
Table 4.--Characteristics of the eight time periods used to integrate constituent loads for Natty Pond Brook, Massachusetts, November 1, 1984 through October 31, 1986

\begin{tabular}{llll}
\hline & \multicolumn{1}{c}{1985} & Winter & \multicolumn{1}{c}{1986} \\
Period: & $\begin{array}{l}\text { December 1984, January-February } 1985 \\
90 \text { days }\end{array}$ & $\begin{array}{l}\text { December 1985, January-February } 1986 \\
90 \text { days }\end{array}$ \\
$\begin{array}{l}\text { Eariy Winter } \\
\text { hydrologic: } \\
\text { vegetation: }\end{array}$ & low flow & vegetal detritus available for transport & $\begin{array}{l}\text { medium flow } \\
\text { vegetal detritus available for transport }\end{array}$ \\
$\begin{array}{c}\text { Late Winter } \\
\text { hydrologic: } \\
\text { vegetation: }\end{array}$ & $\begin{array}{l}\text { rise of high flow from snowmelt } \\
\text { vegetation dormant }\end{array}$ & $\begin{array}{l}\text { rise of high flow from snowmelt with peak } \\
\text { vegetation dormant }\end{array}$ \\
\hline
\end{tabular}

\section{Spring}

$\begin{array}{lll}\text { Period: } & \text { March-May } 1985 & \text { March-May } 1986 \\ 92 \text { days } & 92 \text { days }\end{array}$

\section{Early Spring}

hydrologlc: continual medium to high flow with peak

vegetation: vegetation dormant

continual high flow

vegetation dormant

\section{Late Spring}

hydrologic: recession of high flow

vegetation: vegetation growing

recession of high flow

vegetation growing

\section{Summer}

Perlod: June-August 1985

92 days

June-August 1986

92 days

\section{Early Summer}

hydrologic: base flow with declining water levels

vegetation: vegetation flourishing

medium to low flow with declining water levels

vegetation flourishing

\section{Late Summer}

hydrologic: peaks in streamflow from rainstorms

vegetation: vegetation flourishing

peaks in streamflow from rainstorms, vegetation flourishing

\section{Fall}

\section{Perlod:}

November 1984, September-October 1985 91 days

\section{Early Fall}

hydrologic: low to medium flow

vegetation: vegetal detritus available for transport

\section{Late Fall}

hydrologlc: high flow from rainstorms

vegetation: vegetal detritus available for transport
November 1985, September-October 1986 91 days

high flow from rainstorms

vegetal detritus available for transport

low to high flow from rainstorms

vegetal detirtus available for transport 

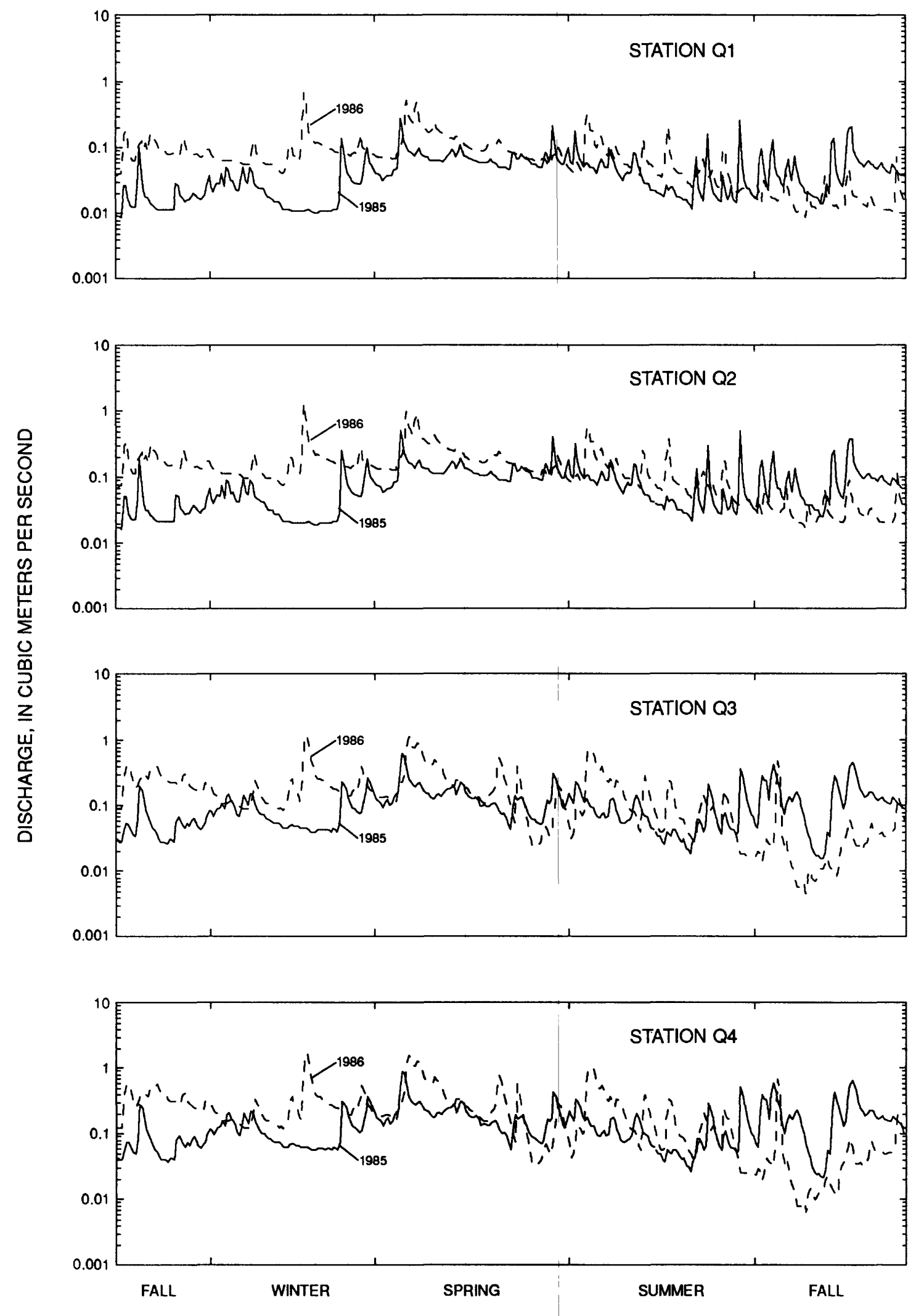

Figure 11.--Daily mean streamflow and seasonal categories for water-quality sites on Natty Pond Brook, Massachusetts, November 1, 1984 through October 31, 1986. 
Table 5.--Comparison of water-quality constituent concentrations and specific conductance in ground water from wells screened in sand-and-gravel and peat deposits, Natty Pond Brook wetland

[m, meters; mg/L, milligrams per liter; $\mu \mathrm{g} / \mathrm{L}$, micrograms per liter; $\mu \mathrm{S} / \mathrm{cm}$, microsiemens per second at 25 degrees Celsius; --, no data]

\begin{tabular}{|c|c|c|c|c|c|}
\hline Constituent & Units & $\begin{array}{l}\text { HXW 43-31 } \\
\text { Sand-and- } \\
\text { gravel well } \\
(9.4 \mathrm{~m})\end{array}$ & $\begin{array}{c}\text { HXW 43-44 } \\
\text { Sand-and- } \\
\text { gravel well } \\
(13.4 \mathrm{~m})\end{array}$ & $\begin{array}{c}\text { HXW 45-03 } \\
\text { Peat } \\
\text { well } \\
(0.9 \mathrm{~m})\end{array}$ & $\begin{array}{c}\text { HXW 45-12 } \\
\text { Peat } \\
\text { well } \\
(2.7 \mathrm{~m})\end{array}$ \\
\hline Nitrate as $\mathrm{N}$ & (mg/L) & 0.01 & 0.01 & 0.01 & 0.01 \\
\hline $\begin{array}{l}\text { Nitrite plus } \\
\text { nitrate as N }\end{array}$ & (mg/L) & .10 & .10 & .10 & .10 \\
\hline Ammonium as $\mathrm{N}$ & (mg/L) & .02 & .04 & 1.30 & 3.70 \\
\hline Kjeldahl as $\mathrm{N}$ & $(\mathrm{mg} / \mathrm{L})$ & .20 & -- & 3.70 & 4.10 \\
\hline $\begin{array}{l}\text { Hydrolyzable plus } \\
\text { orthophosphate } \\
\text { as P }\end{array}$ & (mg/L) & .01 & .02 & .08 & .09 \\
\hline $\begin{array}{l}\text { Orthophosphate } \\
\text { as P }\end{array}$ & (mg/L) & .01 & .01 & .05 & .01 \\
\hline $\begin{array}{l}\text { Total organic } \\
\text { carbon }\end{array}$ & (mg/L) & .90 & .60 & 37 & 15 \\
\hline Chloride & $(\mathrm{mg} / \mathrm{L})$ & 14 & 10 & 3.9 & 1.4 \\
\hline Iron & $(\mu g / L)$ & 3,400 & 9,100 & 5,600 & 1,500 \\
\hline Hydrogen ion & (mg/L) & $7.9 \times 10^{-4}$ & $1.3 \times 10^{-5}$ & $2.5 \times 10^{-4}$ & $2.5 \times 10^{-4}$ \\
\hline $\begin{array}{l}\text { Specific } \\
\text { conductance }\end{array}$ & $(\mu \mathrm{S} / \mathrm{cm})$ & 94 & 115 & 48 & 64 \\
\hline Sulfate & $(\mathrm{mg} / \mathrm{L})$ & 12 & 14 & 18 & 12 \\
\hline
\end{tabular}

\section{Dissoived Oxygen and Biological} Activity

DO in water is the uncombined molecular oxygen gas $\left(\mathrm{O}_{2}\right)$ held in solution and available for the respiration of aquatic organisms. The solubility of oxygen in water depends on water temperature, atmospheric pressure, and the concentration of other solutes in the water. Oxygen-saturation concentrations in water in contact with air at 1 atmosphere of pressure and at 25 ${ }^{\circ} \mathrm{C}$ (degrees Celsius) is $8.32 \mathrm{mg} / \mathrm{L}$ (milligrams per liter). Sources of DO are photosynthesis (oxygen pro- ductivity) and exchanges with the atmosphere at the water surface (physical reaeration). Consumption of DO is caused by respiratory processes of aquatic plants and aerobic bacteria, and chemical oxidation reactions. Because the higher forms of aquatic life, such as fish, require oxygen for survival, DO is widely used as an index in the evaluation of stream-water quality. The extent to which DO can be maintained in a waste-receiving stream depends, in part, on hydraulic properties that affect reaeration. Photosynthesis is not an efficient means of maintaining DO concentrations, because plants produce oxygen only during daylight periods, and then, at night, consume some DO in their metabolic processes. Wastewater effluent 
Table 6.--Water-quality constituent loads from direct precipitation input to wetland, in kilograms, for Natty Pond Brook, by season and stream reach, November 1, 1984 through October 31, 1986

\section{PRECIPITATION INPUT}

\begin{tabular}{|c|c|c|c|c|}
\hline $\begin{array}{l}\text { Season and } \\
\text { stream } \\
\text { reach }\end{array}$ & Ammonium-N & Nitrate-N & Phosphate-P & $\begin{array}{c}\text { Dissolved } \\
\text { organic } \\
\text { carbon }\end{array}$ \\
\hline \multicolumn{5}{|l|}{ 1985: } \\
\hline \multicolumn{5}{|l|}{ Winter } \\
\hline Upper & 12 & 34 & 0.2 & 167 \\
\hline Middle & 19 & 56 & .3 & 273 \\
\hline Lower & 20 & 56 & .3 & 276 \\
\hline \multicolumn{5}{|l|}{ Spring } \\
\hline Upper & 18 & 50 & .3 & 247 \\
\hline Middle & 29 & 82 & .4 & 403 \\
\hline Lower & 29 & 83 & .4 & 407 \\
\hline \multicolumn{5}{|l|}{ Summer } \\
\hline Upper & 32 & 91 & .5 & 444 \\
\hline Middle & 52 & 148 & .8 & 725 \\
\hline Lower & 52 & 149 & .8 & 732 \\
\hline \multicolumn{5}{|l|}{ Fall } \\
\hline Upper & 18 & 53 & .3 & 258 \\
\hline Middle & 30 & 86 & .5 & 421 \\
\hline Lower & 30 & 87 & .5 & 425 \\
\hline \multirow{2}{*}{\multicolumn{5}{|c|}{ 1986: }} \\
\hline & & & & \\
\hline \multicolumn{5}{|l|}{ Winter } \\
\hline Upper & 18 & 52 & .3 & 257 \\
\hline Middle & 30 & 86 & .4 & 419 \\
\hline Lower & 30 & 86 & .5 & 423 \\
\hline \multicolumn{5}{|l|}{ Spring } \\
\hline Upper & 16 & 45 & .2 & 221 \\
\hline Middle & 26 & 74 & .4 & 361 \\
\hline Lower & 26 & 74 & .4 & 365 \\
\hline \multicolumn{5}{|l|}{ Summer } \\
\hline Upper & 27 & 78 & .4 & 382 \\
\hline Middle & 44 & 128 & .7 & 625 \\
\hline Lower & 45 & 129 & .7 & 631 \\
\hline \multicolumn{5}{|l|}{ Fall } \\
\hline Upper & 19 & 54 & .3 & 267 \\
\hline Middle & 31 & 89 & .5 & 436 \\
\hline Lower & 31 & 90 & .5 & 440 \\
\hline
\end{tabular}




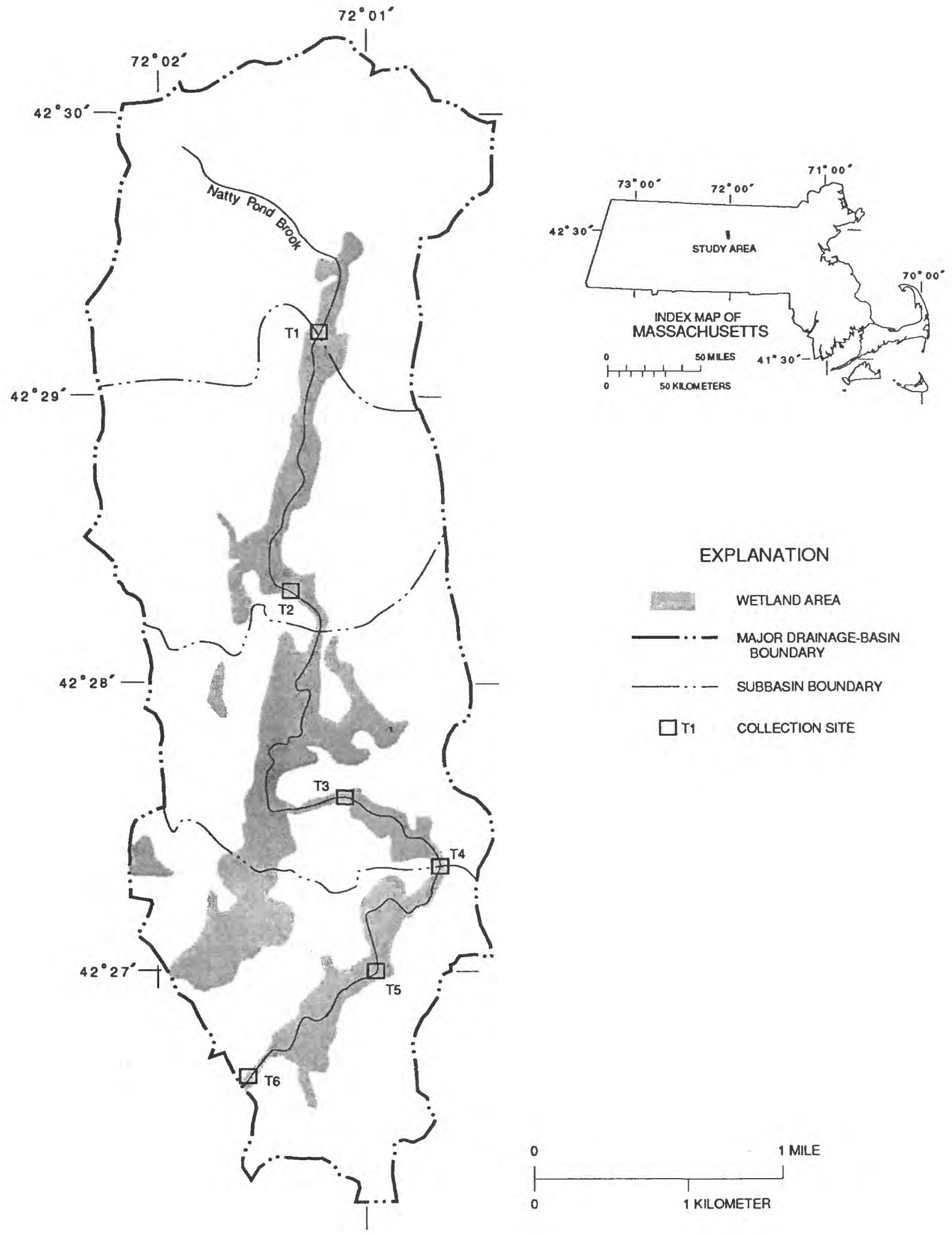

Figure 12.--Time-of-travel data-collection sites and surface-drainage divides of hydrologic-data sites of Natty Pond Brook basin, Massachusetts. 
Table 7.--Summary of travel-time data for dye-tracer sites on Natty Pond Brook, Massachusetts [km, kilometers; $\mathrm{m}^{3} / \mathrm{s}$, cubic meters per second; $h$, hours]

\begin{tabular}{|c|c|c|c|}
\hline $\begin{array}{l}\text { Site } \\
\text { numbers }\end{array}$ & $\begin{array}{l}\text { Reach } \\
\text { length } \\
(\mathrm{km})\end{array}$ & $\begin{array}{l}\text { Disçharge } 1 \\
\left(\mathrm{~m}^{3} / \mathrm{s}\right)\end{array}$ & $\begin{array}{l}\text { Centroid } \\
\text { traveltime } \\
\text { (h) }\end{array}$ \\
\hline \multicolumn{4}{|c|}{ September 1984} \\
\hline Headwaters-site T1 & 0.76 & 0.0091 & 18 \\
\hline Site T1-site T2 & 2.16 & .0091 & 103 \\
\hline Site T2-site T3 & 2.86 & .0091 & 230 \\
\hline \multicolumn{4}{|c|}{ Aprill 1985} \\
\hline Site T4-site T5 & 1.30 & .062 & 17 \\
\hline Site T5-site T6 & 1.61 & .062 & 7 \\
\hline
\end{tabular}

\section{May 1985}

\begin{tabular}{|c|c|c|c|}
\hline Site T3-site T4 & 1.21 & 1.5 & 5 \\
\hline Site T4-site T5 & 1.30 & 1.5 & 7 \\
\hline Site T5-site T6 & 1.61 & 1.5 & 5 \\
\hline \multicolumn{4}{|c|}{ August 1985} \\
\hline Site T3-site T4 & 1.21 & .017 & 14 \\
\hline \multicolumn{4}{|c|}{ June 1986} \\
\hline Site T1-site T2 & 2.16 & .015 & 33 \\
\hline
\end{tabular}

${ }^{1}$ Mean discharge observed at station number Q1 


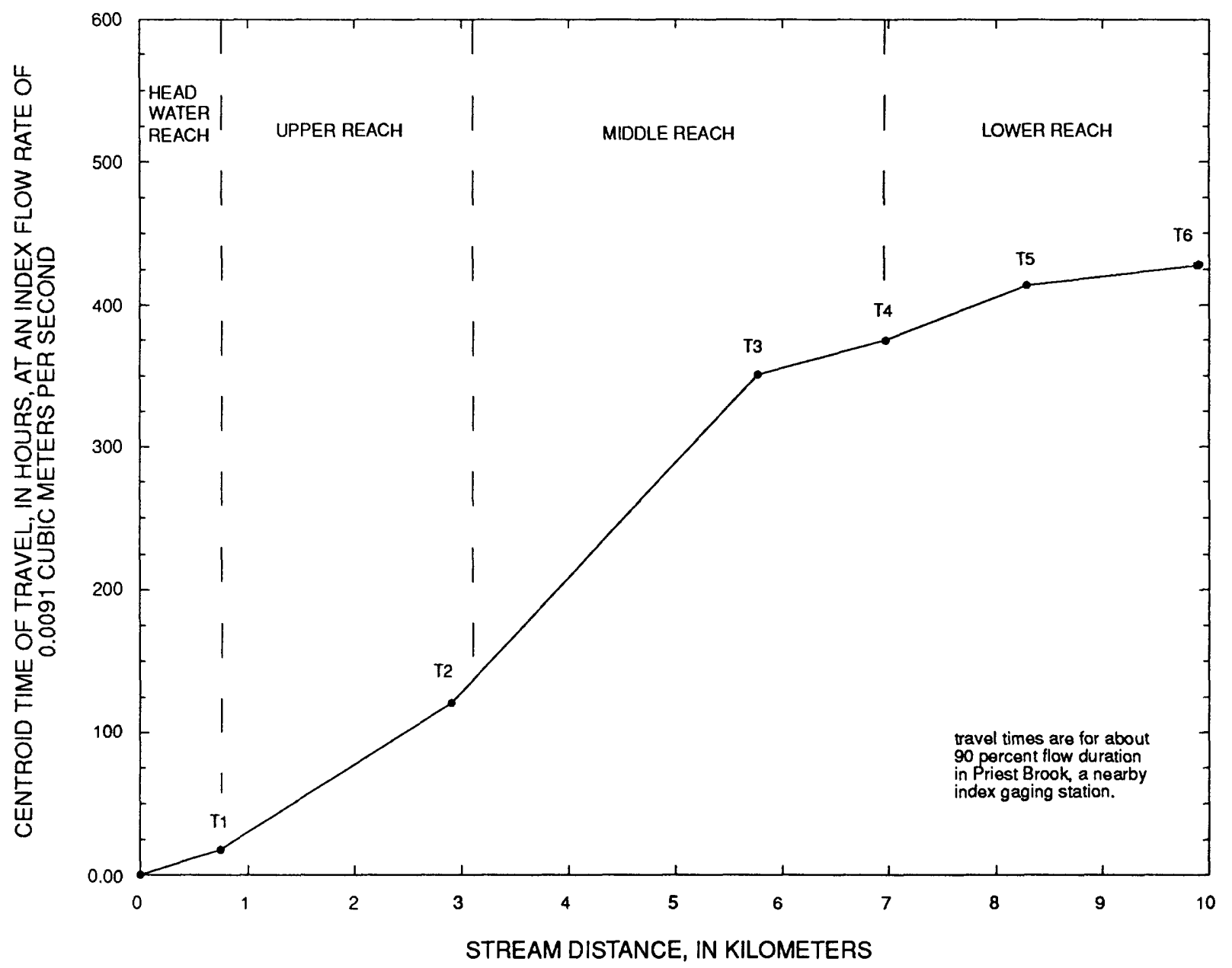

Figure 13.--Centroid travel times of dye cloud from headwater to numbered time-of-travel sites on Natty Pond Brook, Massachusetts.

from sewage-treatment plants typically contains a large load of substances that combine with DO and deplete oxygen concentrations in the receiving stream. Therefore, unless a stream receiving wastewater is reaerated through turbulent flow, the water can become depleted of oxygen so that it will not support higher forms of aquatic life. In wetland systems, natural organic material can be a source of additional oxygen-depleting products that enter a stream and contribute to a decline in DO concentrations. This section describes the wetland's effect on the DO concentration in Natty Pond Brook.

Comparison of DO discharges (fig. 15) entering and leaving each wetland reach show the effects of oxygen-producing and oxygen-demanding processes within wetland areas. The data indicate that, during all seasons except the winter of 1985 , the middle reach acted as a net sink for DO, especially during high-flow periods. Wetland-derived negative discharges of $0 x y-$ gen in the middle reach ranged from about 0 to 8,000 $\mathrm{kg}$ per season. More oxygen was consumed by biological and chemical processes within the reach than produced by photosynthesis, physical reaeration, or from water inflow (drainage accrual). Minimum DO concentrations of 4.7 and $5.5 \mathrm{mg} / \mathrm{L}$ were recorded in the middle and lower reaches. The Class B warmwater standard of the Massachusetts Division of Water Pollution Control (1986) for Natty Pond Brook is $5 \mathrm{mg} / \mathrm{L}$ or saturation of at least 60 percent. This depletion in DO is somewhat similar to the response of the stream to a wastewater discharge.

DO discharge consistently increased through the upper and lower reaches, especially during high-flow periods, indicating that the adjacent wetlands acted as sources of DO. Discharges ranged from about 500 
Table 8.--Summary of computed travel-time data, by individual stream reach, at about 90 percent flow-duration on Natty Pond Brook, Massachusetts

[km, kilometers; $h$, hours; $\mathrm{m} / \mathrm{s}$, meters per second]

\begin{tabular}{lccc}
\hline Reach name & $\begin{array}{c}\text { Reach length } \\
(\mathrm{km})\end{array}$ & $\begin{array}{c}\text { Centroid travel time } \\
(\mathrm{h})\end{array}$ & $\begin{array}{c}\text { Mean velocity } \\
(\mathrm{m} / \mathrm{s})\end{array}$ \\
\hline Headwater & 0.76 & 18 & 0.012 \\
Upper & 2.5 & 130 & .0052 \\
Middle & 3.8 & 230 & .0046 \\
Lower & 2.9 & 30 & .027 \\
\hline
\end{tabular}

to $2,500 \mathrm{~kg}$ per season in the upper reach and about 1,500 to $3,000 \mathrm{~kg}$ per season in the lower reach.

DO loads decreased in the middle reach and increased in the lower reach despite the similar ratios of wetland to total drainage area for both reaches (table 1). Apparently, wetland size alone does not govern the amount of DO transported from wetland areas. Instead, the net effect of a variety of biological, physical, and chemical processes that occur within each reach determined the discharge of $\mathrm{DO}$. Chemical reactions with the large contributions of dissolved organic carbon and dissolved iron are the likely cause of oxygen decrease. During the spring of both years of the study, the wetland as a whole acted as an oxygen sink rather than a source to the stream. Additionally, during the summer of both years, the wetland as a whole was not a significant contributor of oxygen to the stream.

The effect of biological activity on stream-water quality was determined by conducting field studies of oxygen-productivity rates on three stream reaches (P1, P2, and P3, fig. 2) (Parker and Suurballe, 1988). The three reaches included two scrub-shrub wetland areas (reaches P1 and P3) separated by a forested wetland area (reach P2) (fig. 2). The Stephens and Jennings (1976) computer program used to calculate oxygen-productivity rates required that reaches have travel times of less than 24 hours. This constraint required that reach $P 1$ be separated into two subreaches. Wetlands comprise only about 2 percent of the upper part of reach P1 and are assumed to have minimal effect on stream conditions. The lower part of reach P1 is ponded, and effects of the wetland on stream conditions should be more apparent. These studies were conducted to relate differences in net productivity rates for the three stream reaches to differences in physical, hydrologic, and chemical characteristics. The differences in oxygen productivity provide information on the net effect of oxygen-producing and oxygen-demanding processes within each reach resulting from a number of interacting abiotic and biotic characteristics of the wetland system. Variations in stream velocity, light, nutrients, temperature, and even faunal activity can strongly affect primary productivity in streams (Wetzel, 1975, p. 230).

The oxygen-productivity rates determined in both 1985 and 1986 at the downstream end of reach $\mathrm{P} 1$ are nearly equal $\left(1.2\right.$ and $1.1\left(\mathrm{~g} \mathrm{O}_{2} / \mathrm{m}^{3}\right) / \mathrm{d}$ (grams oxygen per cubic meter per day), respectively), even though the measurements were made in different years. This may indicate that the difference in oxygen-productivity measurements for each reach is not an artifact of differences in data-collection periods.

The effect of physical reaeration on stream-water quality was determined by conducting tracer studies on the three reaches (P1, P2, P3, fig. 2). The reaeration coefficients and diffusion constants shown in table 10 are the results of the dye- and gas-tracer analyses. The measured reaeration coefficients are inversely related to the water-surface slopes (kinetic energy level) for the reaches, as described in a statewide analysis by Parker and Gay (1987, p. 14). Reach P1 and P3 had low water-surface slopes $(0.00004 \mathrm{~m} / \mathrm{m})$ and correspondingly low reaeration coefficients $(0.5$ and 1.9 per day (base e units per day), respectively). Reach P2 had a high water-surface slope $(0.005 \mathrm{~m} / \mathrm{m})$ 
1985
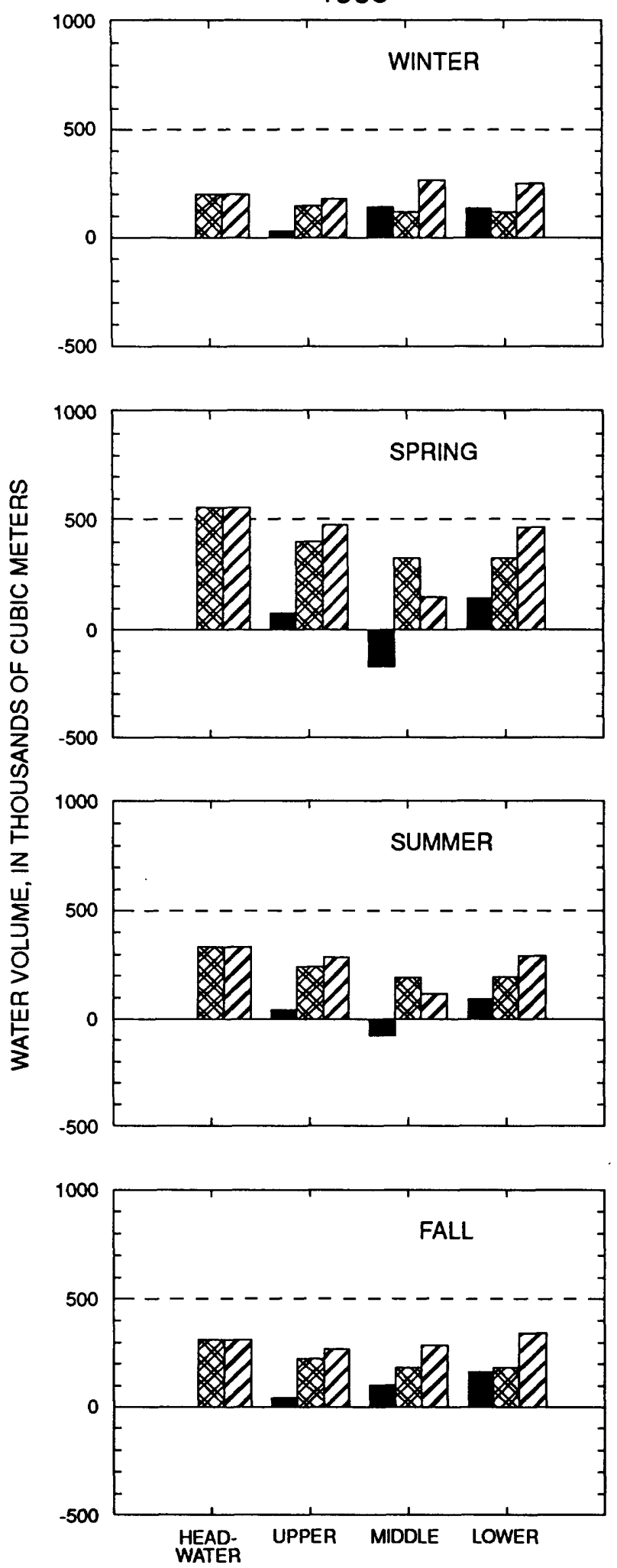

REACH
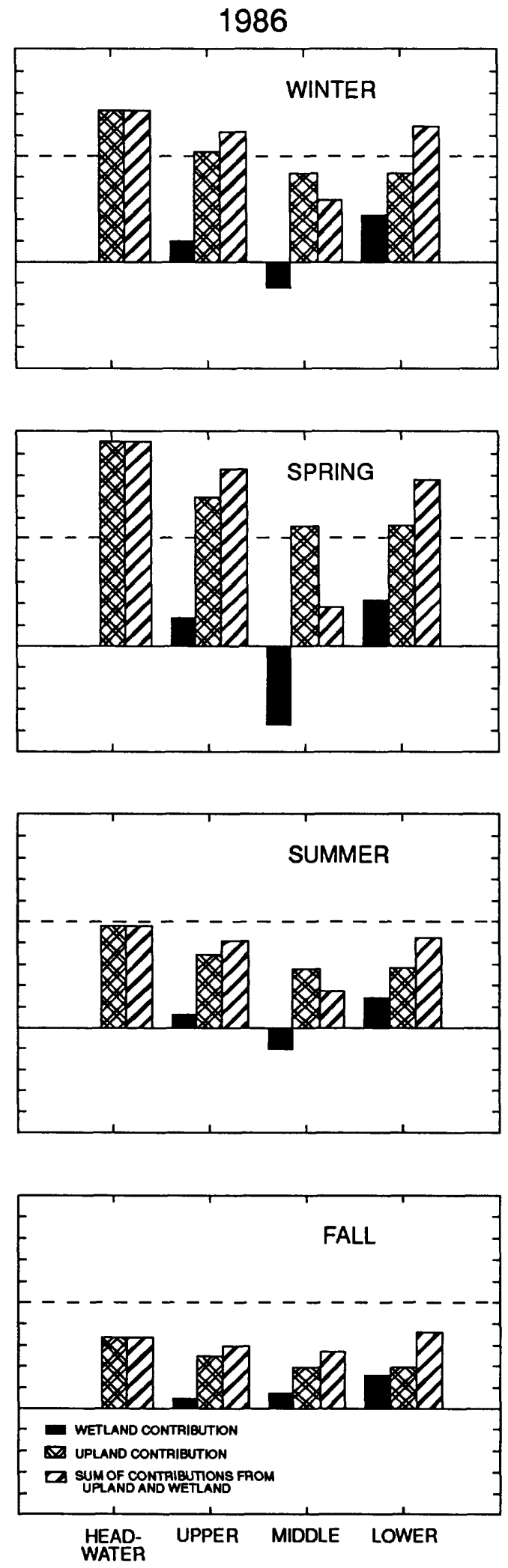

REACH

Figure 14.--Seasonal distribution of streamflow, by individual stream reach, for Natty Pond Brook, Massachusetts, 1985 and 1986. 
Table 9.--Effects of wetland areas on stream-water constituent loads in individual stream reaches, on Natty Pond Brook, Massachusetts

[Net change over reach: +, increase; 0 , no change; decrease]

\section{Wetland reaches}

Constituent

Upper reach Middle reach Lower reach

Dissolved oxygen

Dissolved

ammonium nitrogen

Dissolved nitriteplus-nitrate nitrogen

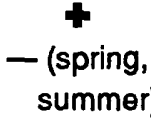

Dissolved sulfate

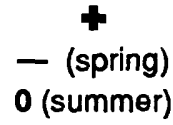

Dissolved organic carbon

Suspended organic carbon

Total hydrogen ion

Total alkalinity

Dissolved iron

Total iron

Dissolved

aluminum

Dissolved hydrolyzable-plusorthophosphate phosphorus and a correspondingly high reaeration coefficient (8.45 per day).

An increase in oxygen-productivity rates from the upstream to downstream end occurred only in reach P1 (table 11). Most of the increase occurred within the upstream part of the reach. This reach had high exposure to sunlight and low color values (20 Pt-Co units (platinum-cobalt units)) indicating that the potential for photosynthetic oxygen production probably was high. Low color values also indicate small concentrations of oxygen-demanding organic acids and chemical oxygen demand. Although DO concentrations increased from 80 percent to 105 percent of saturation in the downstream part of $P 1$, the increase in oxygen productivity in this ponded wetland area was insignificant.

A decrease in oxygen-productivity rates from 1.1 to $-0.7\left(\mathrm{~g} \mathrm{O}_{2} / \mathrm{m}^{3}\right) / \mathrm{d}$ occurred in reach P2. Negative net-productivity rates indicate an excess of oxygen consumption over oxygen production. Oxygen concentrations, however, increased from 75 to 92 percent of saturation in response to the increased diffusion constant of $3.3\left(\mathrm{~g} \mathrm{O}_{2} / \mathrm{m}^{3}\right) / \mathrm{h}$ (grams oxygen per cubic meter per hour) (table 10). This diffusion rate was greater than the rate observed in reach $\mathrm{P} 1\left(0.17\left(\mathrm{~g} \mathrm{O}_{2} / \mathrm{m}^{3}\right) / \mathrm{h}\right)$ and compensates for oxygen demands within the reach. However, oxygen demands are not great here. The increase in color from 20 to 25 Pt-Co units does not indicate high concentrations of oxygen-demanding organic acids. Instead, the decrease in oxygen-production rates through this reach was probably the result of the dense canopy cover that inhibits photosynthetic production by limiting the amount of sunlight exposure to the water surface.

A decrease in daytime oxygen-productivity rates also occurred in reach $\mathrm{P3}$. The rate dropped from $-\mathbf{5 . 3}$ to $-12\left(\mathrm{~g} \mathrm{O}_{2} / \mathrm{m}^{3}\right) / \mathrm{d}$, with an accompanying decrease in DO concentrations from 52 to 29 percent of saturation. High color values (300 Pt-Co units) indicate high concentrations of humic and fulvic acids that increase chemical-oxygen demand. High color may have also reduced light penetration and inhibited photosynthetic oxygen production.

Researchers investigating changes in lakes and streams have described systems based on the types of biota, water depth, transparency, temperature, velocity, and nutrient status. These systems are commonly considered oligotrophic or eutrophic, according to Naumann's classification (Hutchinson, 1957, p. 379). Thienemenn added a third category, dystrophic, in consideration of the interaction of basin morphology 
1985
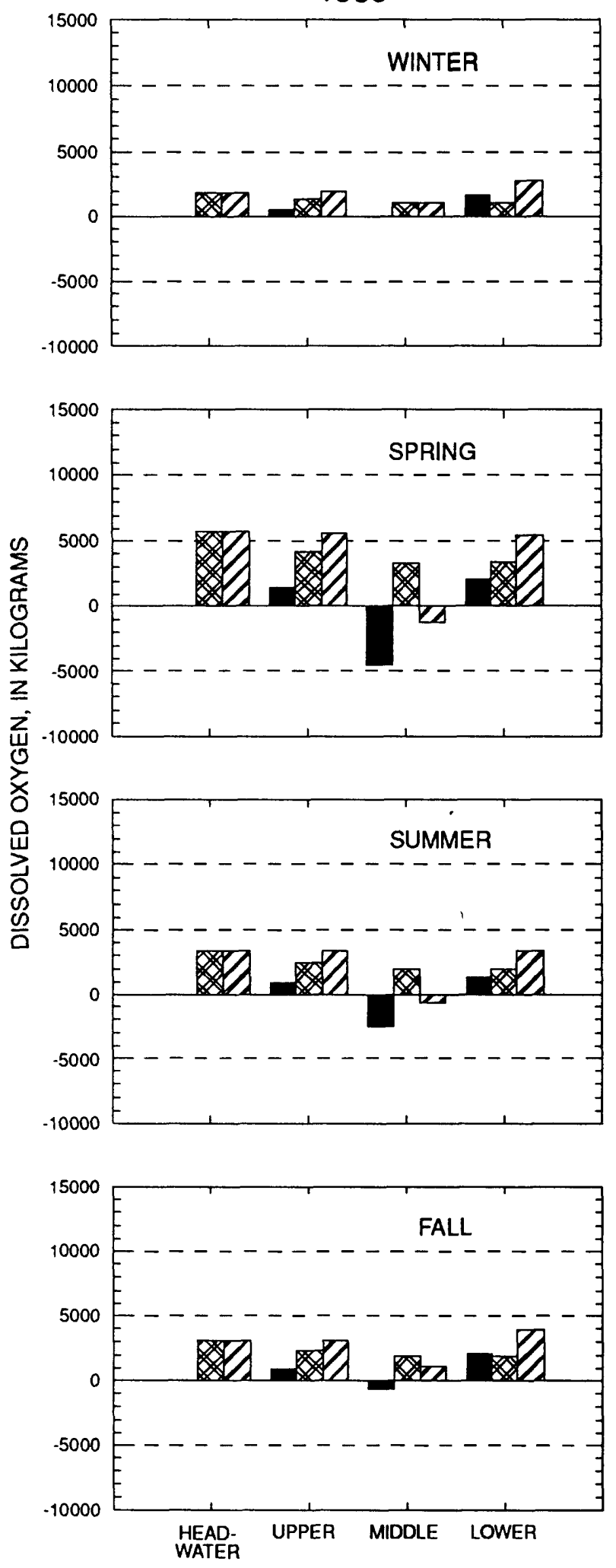
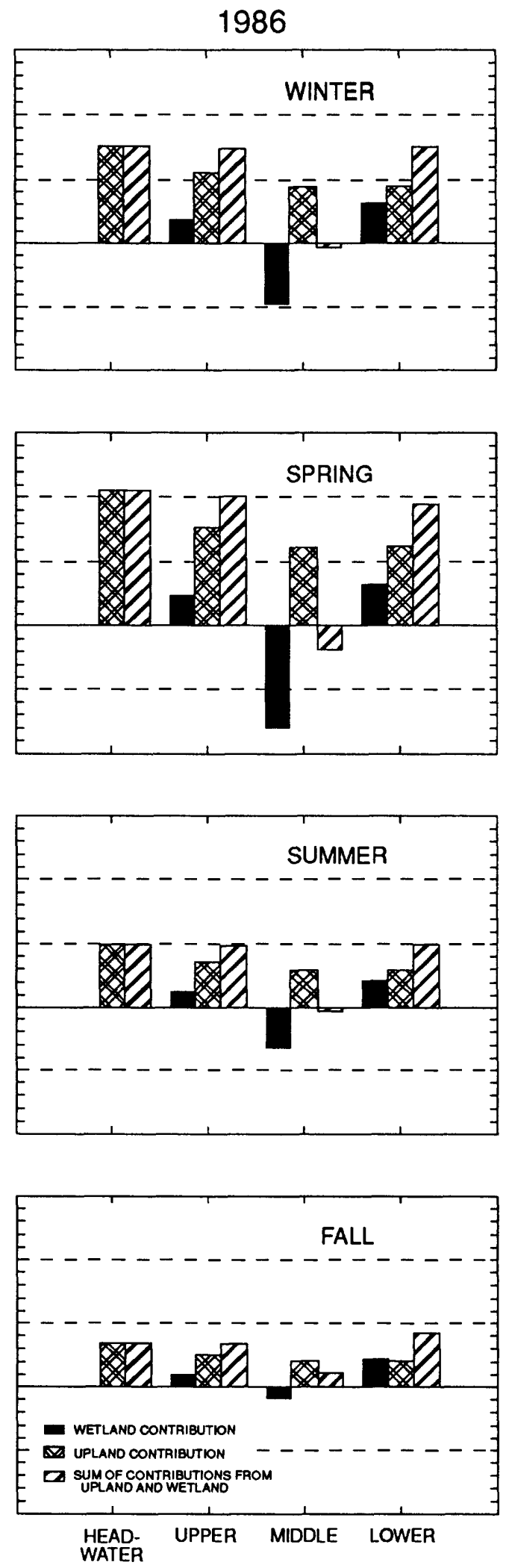

REACH

Figure 15.--Seasonal discharge of dissolved oxygen, by individual stream reach, for Natty Pond Brook, Massachusetts, 1985 and 1986. 
Table 10.--Reach characteristics and results of tracer and oxygen-productivity studies

$\left[\mathrm{m} / \mathrm{m}\right.$, meter per meter; Pt-Co, platinum-cobalt units; $\mathrm{d}^{-1}$, base e units per day; $\left(\mathrm{g} \mathrm{O}_{2} / \mathrm{m}^{3}\right) / \mathrm{h}$, grams oxygen per cubic meter per hour]

\begin{tabular}{cccccc}
\hline $\begin{array}{c}\text { Productivity } \\
\text { reach }\end{array}$ & $\begin{array}{c}\text { Wetland } \\
\text { type }\end{array}$ & $\begin{array}{c}\text { Water surface } \\
\text { slope } \\
(\mathrm{m} / \mathrm{m})\end{array}$ & $\begin{array}{c}\text { Color } \\
(\mathrm{Pt}-\mathrm{Co} \text { units })\end{array}$ & $\begin{array}{c}\text { Reaeration } \\
\text { coefficient } \\
\left(\mathrm{d}^{-1}\right)\end{array}$ & $\begin{array}{c}\text { Diffusion } \\
\text { constant } \\
\left(\left(\mathrm{g} \mathrm{O}_{2} / \mathrm{m}^{3}\right) / \mathrm{h}\right)\end{array}$ \\
\hline $\mathrm{P} 1$ & scrub/shrub & 0.00004 & 20 & 0.5 & 0.17 \\
$\mathrm{P} 2$ & forested & .005 & 25 & 8.5 & 3.3 \\
$\mathrm{P3}$ & scrub/shrub & .00004 & 300 & 1.9 & .75 \\
\hline
\end{tabular}

and nutrient status (Hutchinson, 1957, p. 380). Natty Pond Brook and the contiguous wetland are much like a dystrophic system. The headwater reach of Natty Pond Brook functions as an oligotrophic system with positive productivity, high DO saturation concentrations, and high water transparency. As the stream flows through wetlands, it functions increasingly like a dystrophic system. More oxygen is consumed than is produced by photosynthesis. Further, color values increase, demonstrating the increase of humic-substances concentrations. Between $\mathrm{Q} 1$ and $\mathrm{Q} 4$, median values increased from 20 to $55 \mathrm{Pt}$-Co units and maximum values increased from 55 to $500 \mathrm{Pt}$-Co units. The presence of humic material in reaches with a large percentage of wetland area to total intervening drain- age area suggests that some mechanism exists whereby drainage accrual enters the stream directly from the organic layer in the wetland areas. The result is that chemical and biological oxidation of this humic material depresses DO concentration in the stream.

Furthermore, basin morphometry plays an important role in affecting water quality. The middle reach, with its extremely low slope, is typical of aquatic environments where the area of contact between wetland water and sediment is great and dissolved humic material enters the slowly moving stream by the discharge of peat water. Stream residence times are greatest through the middle reach.

Table 11.--Results of oxygen-productivity studies

[( $\left.\mathrm{g} \mathrm{O}_{2} / \mathrm{m}^{3}\right) / d$, grams oxygen per cubic meter per day]

\begin{tabular}{|c|c|c|c|c|c|}
\hline & $\begin{array}{l}\text { Productivity } \\
\text { reach }\end{array}$ & Date & $\begin{array}{c}\text { Dissolved } \\
\text { oxygen } \\
\text { (percent saturation) }\end{array}$ & $\begin{array}{c}\text { Net daytime } \\
\text { productivity } \\
\left(\left(\mathrm{g} \mathrm{O}_{2} / \mathrm{m}^{3}\right) / \mathrm{d}\right)\end{array}$ & $\begin{array}{c}\text { Nighttime } \\
\text { respiration } \\
\left(\left(\mathrm{g} \mathrm{O}_{2} / \mathrm{m}^{3}\right) / \mathrm{d}\right)\end{array}$ \\
\hline \multirow[t]{2}{*}{$\mathrm{P} 1$} & $\begin{array}{l}\text { upstream end } \\
\text { middle of reach }\end{array}$ & $6 / 25 / 86$ & $\begin{array}{l}77 \\
74\end{array}$ & $\begin{array}{c}+0.02 \\
+.8\end{array}$ & $\begin{array}{r}-0.5 \\
-1.1\end{array}$ \\
\hline & $\begin{array}{l}\text { middle of reach } \\
\text { downstream end }\end{array}$ & $6 / 26 / 86$ & $\begin{array}{r}80 \\
105\end{array}$ & $\begin{array}{r}+1.2 \\
+1.2\end{array}$ & $\begin{array}{l}-1.6 \\
-1.2\end{array}$ \\
\hline P2 & $\begin{array}{l}\text { upstream end } \\
\text { downstream end }\end{array}$ & $8 / 20 / 85$ & $\begin{array}{l}75 \\
92\end{array}$ & $\begin{array}{r}+1.1 \\
-.7\end{array}$ & $\begin{array}{r}-1.1 \\
-.6\end{array}$ \\
\hline P3 & $\begin{array}{l}\text { upstream end } \\
\text { downstream end }\end{array}$ & $9 / 17 / 85$ & $\begin{array}{l}52 \\
29\end{array}$ & $\begin{array}{l}-5.3 \\
-12\end{array}$ & $\begin{array}{l}-4.0 \\
-9.0\end{array}$ \\
\hline
\end{tabular}


By prolonging the period over which the stream receives drainage from organic peat and facilitating the inflow of oxygen-demanding organic acids, the increased residence time affects oxygen levels. Stream oxygen is consumed by the oxidation of humic material faster than oxygen can be replaced through reaeration.

Because biological activity affects DO concentrations in stream water, this activity can indirectly have important effects on other chemical constituents. The concentrations of oxygen in the bottom sediments and the water column govern chemical transformations and nutrient cycling in wetlands (Mitsch and Gosselink, 1986, p. 95). On the basis of the DO in the wetland reaches of Natty Pond Brook, chemical reactions involving nutrients may help explain differences in water-quality loads through the wetland.

\section{Nitrogen}

Nitrogen in water is present as nitrite or nitrate $\left(\mathrm{NO}_{2}\right.$ and $\mathrm{NO}_{3}$, respectively), as ammonium cations $\left(\mathrm{NH}_{4}{ }^{+}\right)$, and as part of organic solutes. In aquatic habitats, algae and macrophytes rely on dissolved nitrogen compounds for nutrients. Excessive nutrient loading of a water body increases plant productivity, causing rapid multiplication of algal populations ("blooms") that may severely limit its uses. Decomposing algae from die-off of blooms commonly create high oxygen demands, rendering the water unsuitable for desirable aquatic organisms, such as fish. For these reasons, the nitrogen content of surface water is an important indicator of water quality.

In wetland systems, nitrogen is present in many of the products of organic-material degradation. As nitrogen-containing compounds break down, a variety of chemical transformations can occur. Ammonification, the production of dissolved ammonia from the breakdown of organic nitrogen, is the principal source of ammonia in most aquatic systems.

If oxygen is readily available, nitrification can then occur, further oxidizing ammonium to nitrate, as follows:

$$
\mathrm{NH}_{4}^{+}+2 \mathrm{O}_{2}=\mathrm{NO}_{3}^{-}+2 \mathrm{H}^{+}+\mathrm{H}_{2} \mathrm{O}
$$

In the absence of free oxygen, bacteria may use nitrate as an alternative electron receptor, thereby reducing nitrate to nitrite (Manahan, 1975, p. 122-3). DO concentrations in the water column appear to govern the species of nitrogen transported from wetland areas.

Nitrogen yielded by wetland reaches of Natty Pond Brook was in the form of ammonium. The upper reach, with relatively high concentrations of $\mathrm{DO}$ (table $3)$, had the lowest discharge of ammonium nitrogen (fig. 16)--about 20 to $50 \mathrm{~kg}$ per season, partly because the relatively small wetland does not serve as a major source of organic material and partly because DO is available to oxidize ammonium to nitrate.

Wetland reaches of Natty Pond Brook did not yield the nitrite or nitrate form of nitrogen. In most cases, the nitrite-plus-nitrate load from each reach was less than that from direct precipitation on the wetland areas (table 6) and from upland inputs (fig. 17). During the extreme high-flow periods of winter and spring 1986, however, the discharges from the upper and lower reaches (approximately 60 and 100 kg nitrite-plus-nitrate nitrogen, respectively) did exceed the amount that entered from precipitation (approximately 50 and $80 \mathrm{~kg}$ nitrate nitrogen, respectively). Because the stream entering the wetland contained only low concentrations of nitrogen (about $0.02 \mathrm{mg} / \mathrm{L}$ ), the ability of the wetland to assimilate nitrogen was not tested.

In the middle reach, nitrite-plus-nitrate nitrogen yields showed a strong seasonal trend and did not exceed the amount that entered from precipitation (table 6 and fig. 17) even during high-flow periods. The amount of the nitrite-plus-nitrate nitrogen transported from the middle reach decreased during the growing season, as indicated by the negative discharges (retention) that ranged from about 5 to $50 \mathrm{~kg}$ per season. Because wetland-retention was also indicated during the nongrowing period ( $15 \mathrm{~kg}$ in winter 1986), factors other than plant uptake seem to affect the amount of nitrite-plus-nitrate nitrogen transported from wetland reaches. The middle reach had the highest wetland-derived discharges of ammonium, ranging from about 30 to $200 \mathrm{~kg}$ per season, and relatively low concentrations of oxygen. The large wetland may serve as a source of nitrogen-containing organic material that breaks down to form ammonium. Nitrification may be limited in the reach because of the low oxygen concentrations (Richardson and others, 1978, p. 229). If the wetland sediments become greatly depleted of oxygen, nitrate reduction can occur. This may explain why most of the nitrogen is in the form of ammonium; nitrate may be reduced 
1985
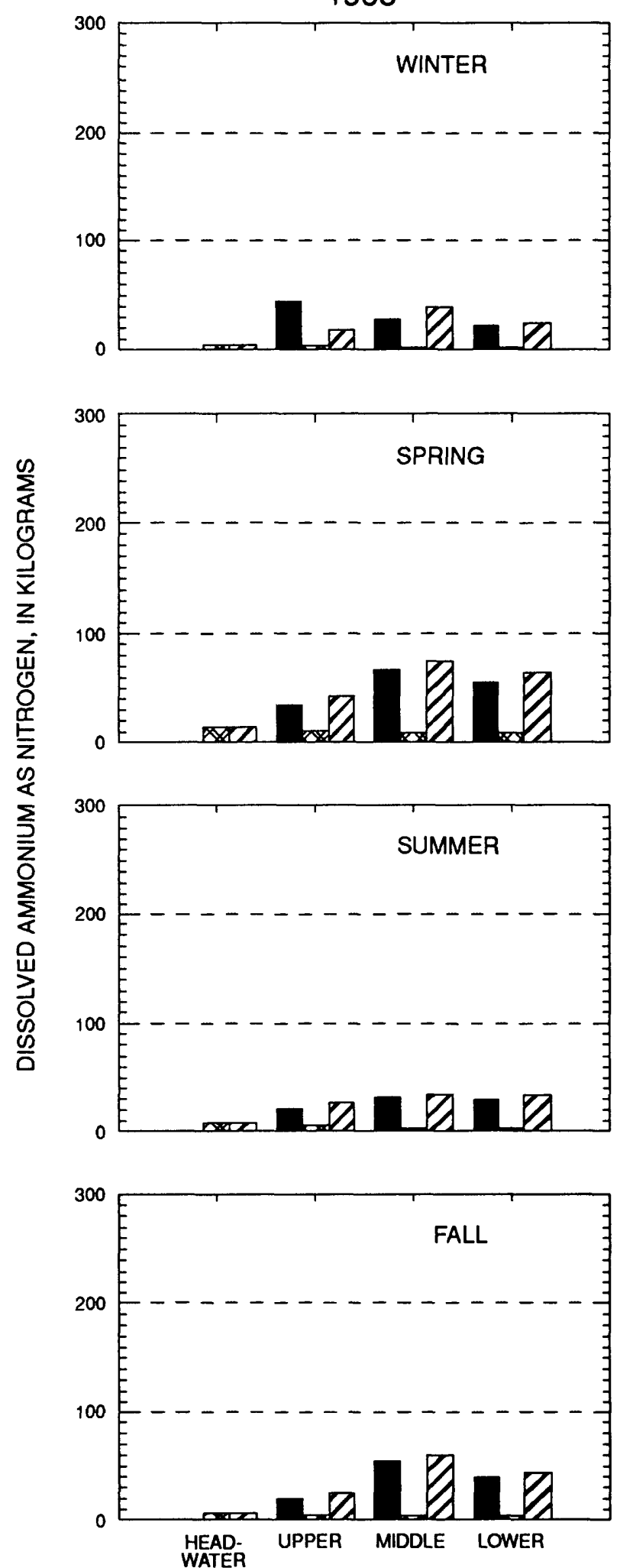

REACH
1986
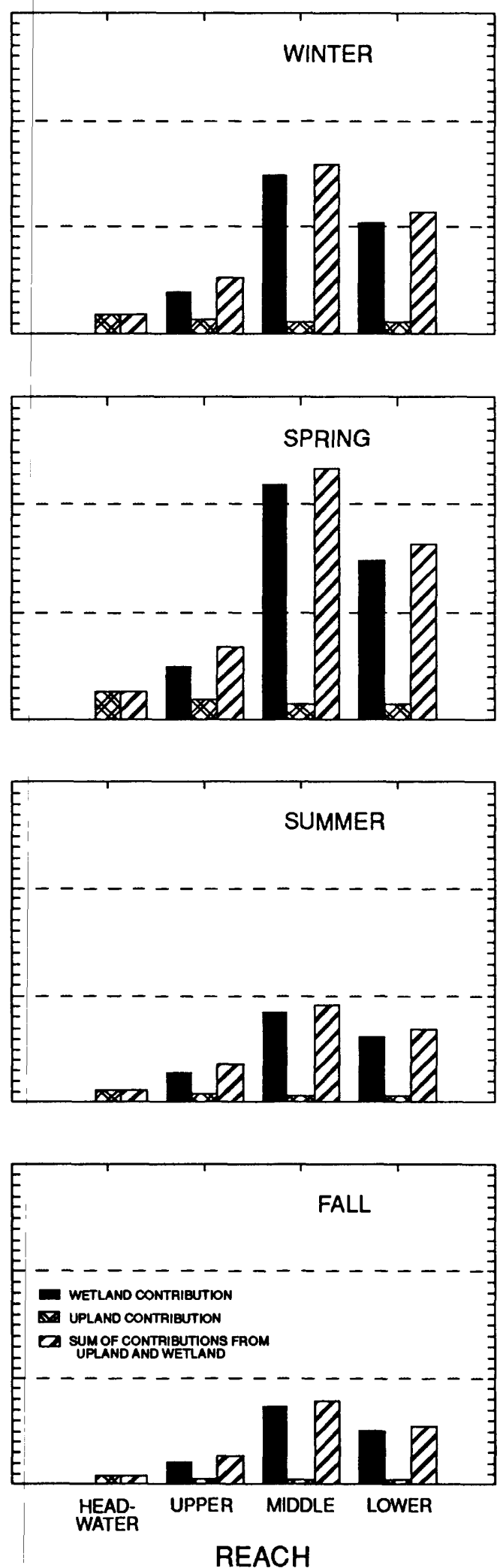

Figure 16.--Seasonal discharge of dissolved ammonium as nitrogen, by individual stream reach, for Natty Pond Brook, Massachusetts, 1985 and 1986. 
1985
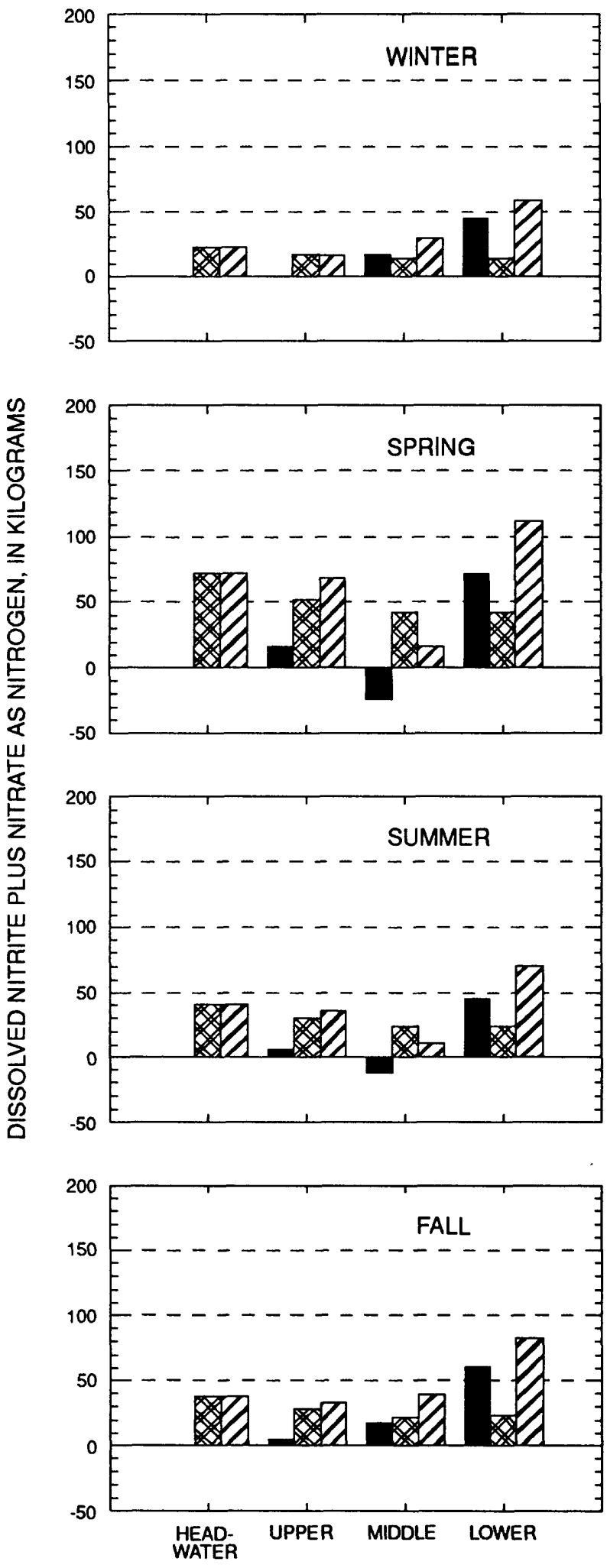

REACH
1986
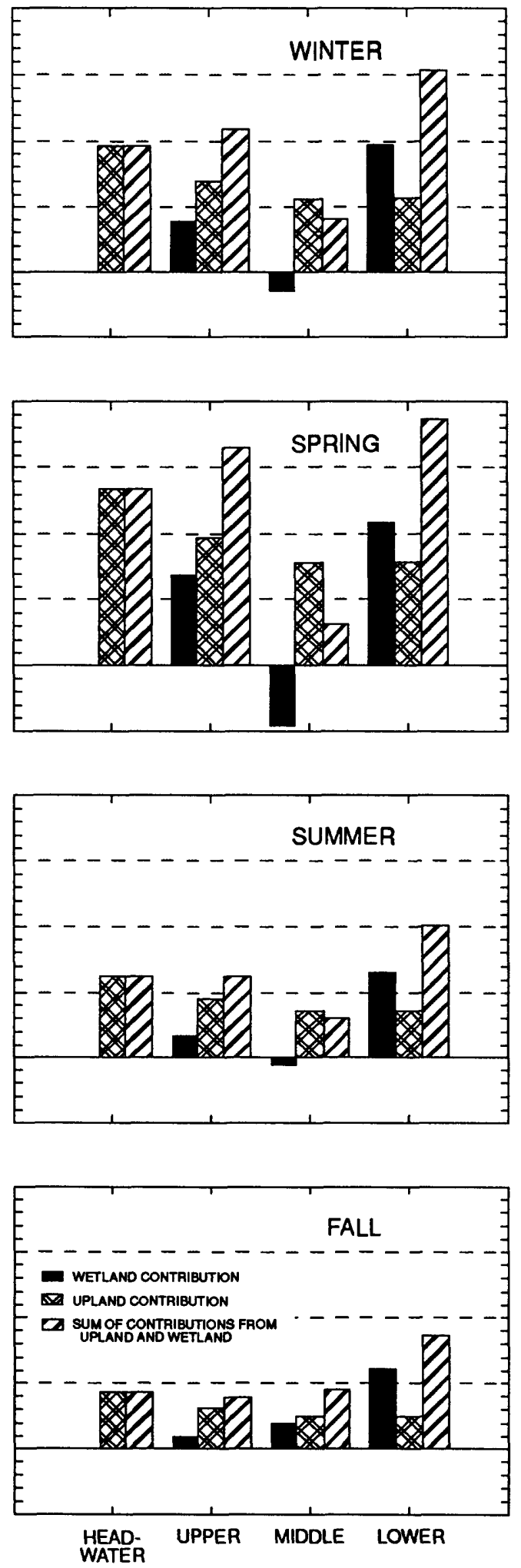

REACH

Figure 17.--Seasonal discharge of dissolved nitrite plus nitrate às nitrogen, by individual stream reach, for Natty Pond Brook, Massachusetts, 1985 and 1986. 
by bacteria or readily consumed by plants during the growing season. During the long contact time that water remains within this poorly-oxygenated reach (table 8), the nutrient seems to be reduced by bacteria faster than it is imported.

A slight decrease in ammonium nitrogen discharges, (from about 20 to $150 \mathrm{~kg}$ per season) and an increase in nitrite-plus-nitrate nitrogen discharges (ranging from about 50 to $100 \mathrm{~kg}$ per season) occurred in the lower reach. Oxygen yields exceeded the amount of oxygen that entered from upland areas and the previous reach. No seasonal trend in nitrogen retention was observed, indicating that oxygen concentrations were not as limiting as they had been in the middle reach. Further, inflow to this reach appears to be an adequate source of plant nutrients. Stream water also may be moving too quickly for a noticeable amount of transported nutrient to be immobilized by bacteria.

Differences in the amounts of ammonium nitrogen and nitrite-plus-nitrate nitrogen transported from the three wetland reaches are probably related to the size of the wetland that serves as a source of organic material, and to the biological activity that affects the transformation of nitrogen and the uptake of the nutrient by plants. Because the ammonification and nitrification reactions consume oxygen, the species of nitrogen transported from each reach relates to the amount of DO present in the water column. Stream-water-residence times are also related to DO concentrations.

The entire wetland contributed small gains in ammonium nitrogen concentrations to the stream. Median concentrations were $0.02 \mathrm{mg} / \mathrm{L}$ at $\mathrm{Q} 1$ and 0.06 $\mathrm{mg} / \mathrm{L}$ at $\mathrm{Q} 2$. Between $\mathrm{Q} 2$ and $\mathrm{Q4}$, median concentrations remained constant while maximum concentrations increased from 0.04 to $0.82 \mathrm{mg} / \mathrm{L}$, respectively. Nitrification seems to be limited in anaerobic areas, thereby keeping nitrogen in the form of ammonium. The entire wetland contributed negligible gains in nitrite-plus-nitrate nitrogen concentrations to the stream. Median concentrations were $<0.1 \mathrm{mg} / \mathrm{L}$ at Q1 and $0.11 \mathrm{mg} / \mathrm{L}$ at $\mathrm{Q} 4$. Nitrate reduction in anaerobic areas caused the concentration to drop to below the detection level at Q3, indicating that DO concentrations governed the species of nitrogen transported.
Sulfur

Organic-sulfur compounds are common in wetland sediments. When these compounds are degraded, the initial product is hydrogen sulfide $\left(\mathrm{H}_{2} \mathrm{~S}\right)$. Hydrogen sulfide, identified by its rotten-egg odor, is highly toxic to microbes and rooted plants. For this reason, the sulfur content of surface water can cause serious water-quality problems.

If $\mathrm{DO}$ is readily available, bacteria convert the reduced form of sulfur $\left(\mathrm{H}_{2} \mathrm{~S}\right)$ to the oxidized form $\left(\mathrm{SO}_{4}{ }^{2-}\right)$. This is analogous to the microbe-mediated oxidation of reduced nitrogen $\left(\mathrm{NH}_{4}{ }^{+}\right)$. If bottom sediments become depleted of oxygen, sulfur-reducing bacteria may convert sulfate to sulfide through anaerobic respiration, as follows (Mitsch and Gosselink, 1986, p. 100):

$$
4 \mathrm{H}_{2}+\mathrm{SO}_{4}^{2-}=\mathrm{H}_{2} \mathrm{~S}+2 \mathrm{H}_{2} \mathrm{O}+2 \mathrm{OH}^{-} .
$$

During most nongrowing periods, more sulfate was transported from each reach than entered from direct precipitation on the wetland (table 6) and from upland inputs (fig. 18). Wetland-derived loads of sulfate increased downstream. The upper reach, with relatively high concentrations of DO (table 3 ), discharges the lowest amount of wetland-derived sulfate-about 500 to $1,500 \mathrm{~kg}$ per season. The relatively small wetland in this reach is not a major source of organic material. The presence of plentiful DO in this reach suggests that sulfur compounds are readily oxidized to sulfate.

In the middle reach, the amount of sulfate transported decreased during the growing season. During spring periods, relatively small amounts of sulfate ranging from about 500 to $1,500 \mathrm{~kg}$ were retained within the reach. During summer and winter 1986, yields from the wetland were less than the amount that entered from direct precipitation on the wetland. During the other periods, moderate amounts of sulfate (about $1,700 \mathrm{~kg}$ per season) discharged from wetland areas within the reach. The large wetland area of the middle reach may serve as a source of organic material that breaks down to form sulfate. However, if the wetland sediments become depleted of oxygen, sulfate reduction can occur. This may explain why sulfate discharges decreased during several periods. The long residence time in this reach, coupled with low DO concentrations, may be the cause of the decrease in sulfate discharge, regardless of season. During the 
1985
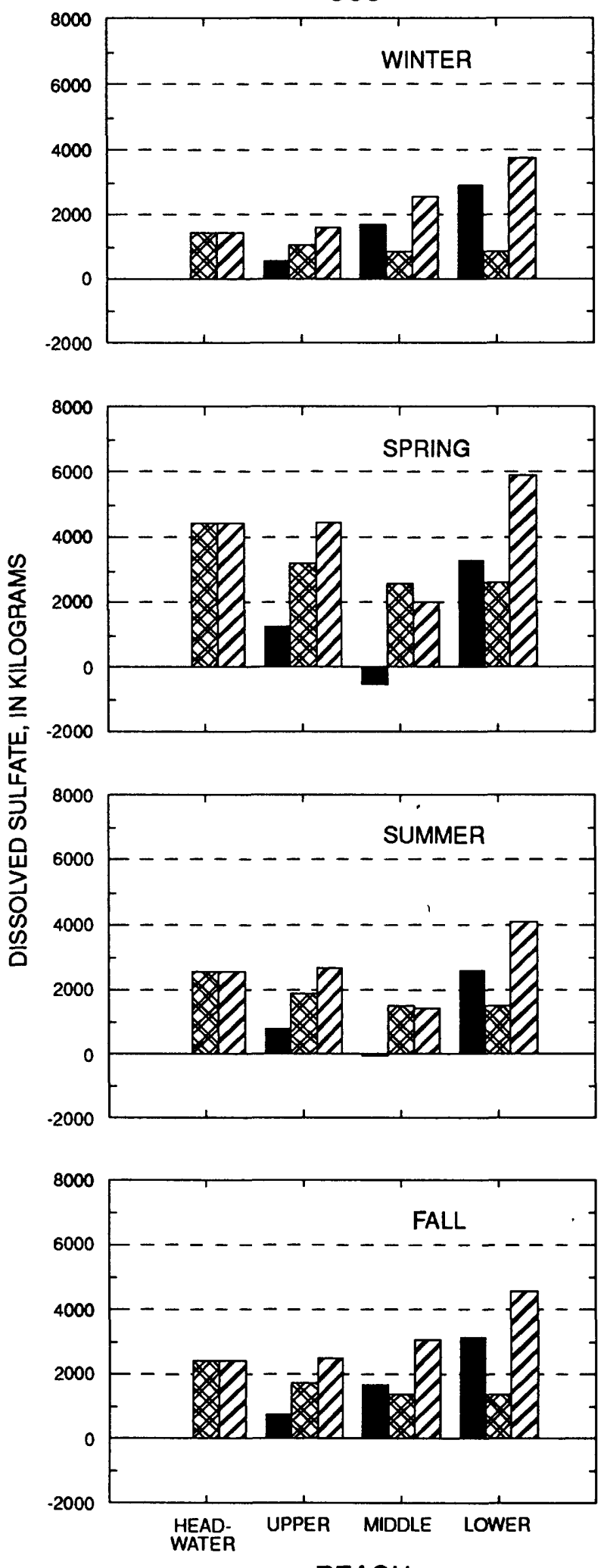

1986
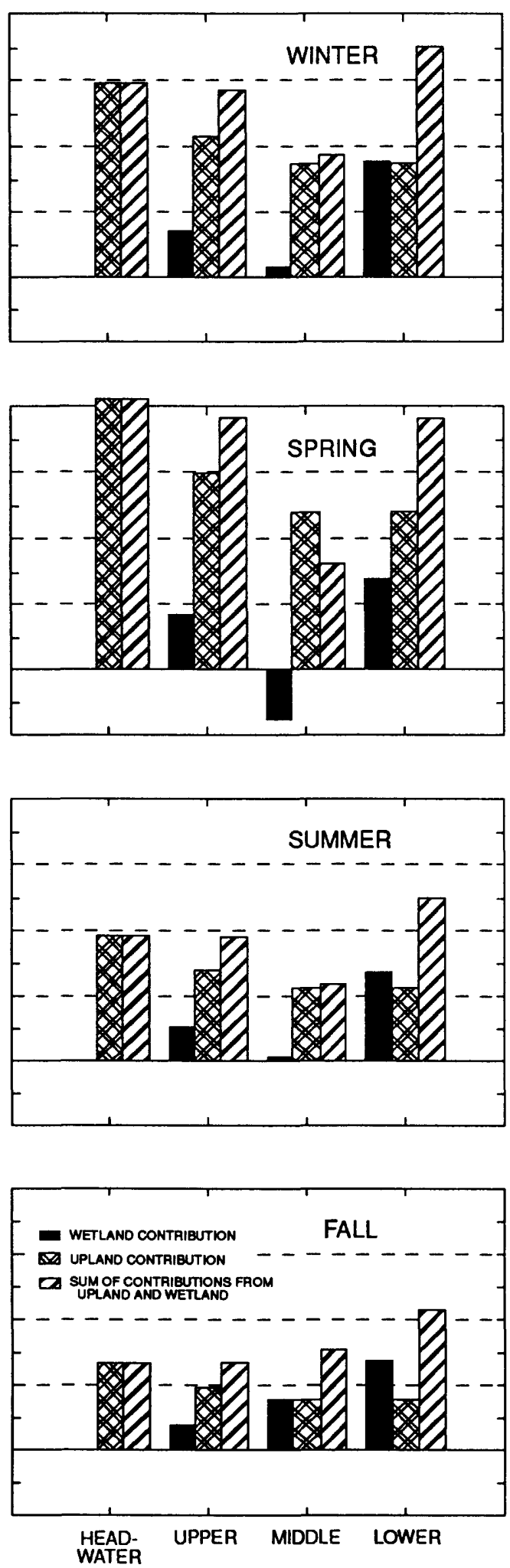

REACH

Figure 18.--Seasonal discharge of dissolved sulfate, by individual stream reach, for Natty Pond Brook, Massachusetts, 1985 and 1986. 
long contact time that water remains within this poorly-oxygenated reach (table 8), more sulfate seems to be reduced by bacteria than is imported. During the growing season, sulfate loads decreased even further, as biological activity rates increased.

The lower reach, with increased oxygen concentrations and greatly reduced residence time, consistently yielded sulfate (about $3,000 \mathrm{~kg}$ per season). Further, no seasonal trend in sulfate retention was observed. This suggests that oxygen concentrations were not as limiting during periods of increased biological activity as they had been in the middle reach. Stream water may also be flowing through the reach too quickly for a noticeable amount of transported constituent to be immobilized by bacteria.

The differences in the amount of sulfate transported from the three wetland reaches probably are related to the biological activity that influences the transformation of the constituent. Disparities in the yields from the middle and lower reaches suggest that the size of the wetland may be a secondary controlling factor. The species of sulfur transported from each reach appears to be governed by the amount of DO present in the water column and by the residence time of the stream water.

The entire wetland contributed negligible gains in sulfate concentrations to the stream. Median concentrations of sulfate were $7.3 \mathrm{mg} / \mathrm{L}$ at $\mathrm{Q} 1$ and 10.5 $\mathrm{mg} / \mathrm{L}$ at Q4. Reduction of sulfate to hydrogen sulfide in anaerobic areas seems to keep the concentrations of sulfate within this narrow range.

\section{Organic Carbon}

The concentration of dissolved organic carbon is greater in wetlands than in other aquatic systems, because wetland systems typically produce large amounts of vegetative matter containing organic carbon that leaches by slow-moving wetland water. Most of the dissolved organic carbon present in wetland water is organic acid known as humic and fulvic substances. These yellow organic acids give wetland water its characteristic tea color. Humic substances can bind to and transport pollutants in natural water systems, and humic substances have been shown to be trihalomethane precursors. For these reasons, streams containing humic and fulvic substances are of limited use as drinking-water sources.
The amount of dissolved organic carbon that discharges from wetland systems depends on whether carbon is broken down by bacteria in the presence of oxygen (aerobically) or in the absence of oxygen (anaerobically). If oxygen is readily available, organic matter $\left(\mathrm{CH}_{2} \mathrm{O}\right)$ oxidizes to form carbon dioxide and water, as follows:

$$
\left(\mathrm{CH}_{2} \mathrm{O}\right)+\mathrm{O}_{2}=\mathrm{CO}_{2}+\mathrm{H}_{2} \mathrm{O}+\text { Energy }
$$

where $\left(\mathrm{CH}_{2} \mathrm{O}\right)$ is a generalized organic carbon compound.

Also, a number of anaerobic processes can break down organic carbon. A major process of organic-matter biodegradation in wetland systems is fermentation. This process, in which high molecular-weight carbohydrates are broken down to dissolved organic carbon, is accomplished in wetland sediments by anaerobes, as follows:

$$
\left(\mathrm{CH}_{2} \mathrm{O}\right)+\mathrm{R} \text { (oxidized) }=\mathrm{CO}_{2}+\mathrm{R}(\text { reduced })
$$

where $R$ is an organic compound that serves as an electron acceptor in the absence of oxygen (Thurman, 1985, p. 437). The product of this reaction is a low-molecularweight organic compound that contributes to the dissolved organic pool.

Small amounts of dissolved organic carbon were retained in the upper reach, ranging from about 5 to $500 \mathrm{~kg}$ per season (fig. 19). Large amounts of dissolved organic carbon were contributed to the stream from the middle and lower reaches, the middle reach yielded the greatest discharges of about 6,000 to $10,000 \mathrm{~kg}$ per season (fig. 19). Discharges of dissolved organic carbon in the lower reach (about 2,000 to 6,000 $\mathrm{kg}$ per season) were less than those for the middle reach, despite the similar ratios of wetland area to total drainage area for the two reaches (table 1). Wetland size is not the only characteristic that determines wetland yields of dissolved organic carbon. DO concentrations appear to play a major role in the relative amounts of organic carbon load observed in the stream.

Loads of organic carbon generated in the peat and contributed to the stream by peat water discharge had the greatest effect on the stream as it passed through the middle reach. This effect occurred because of the greater residence time of the stream water in the middle reach relative to that in the other reaches. 
1985
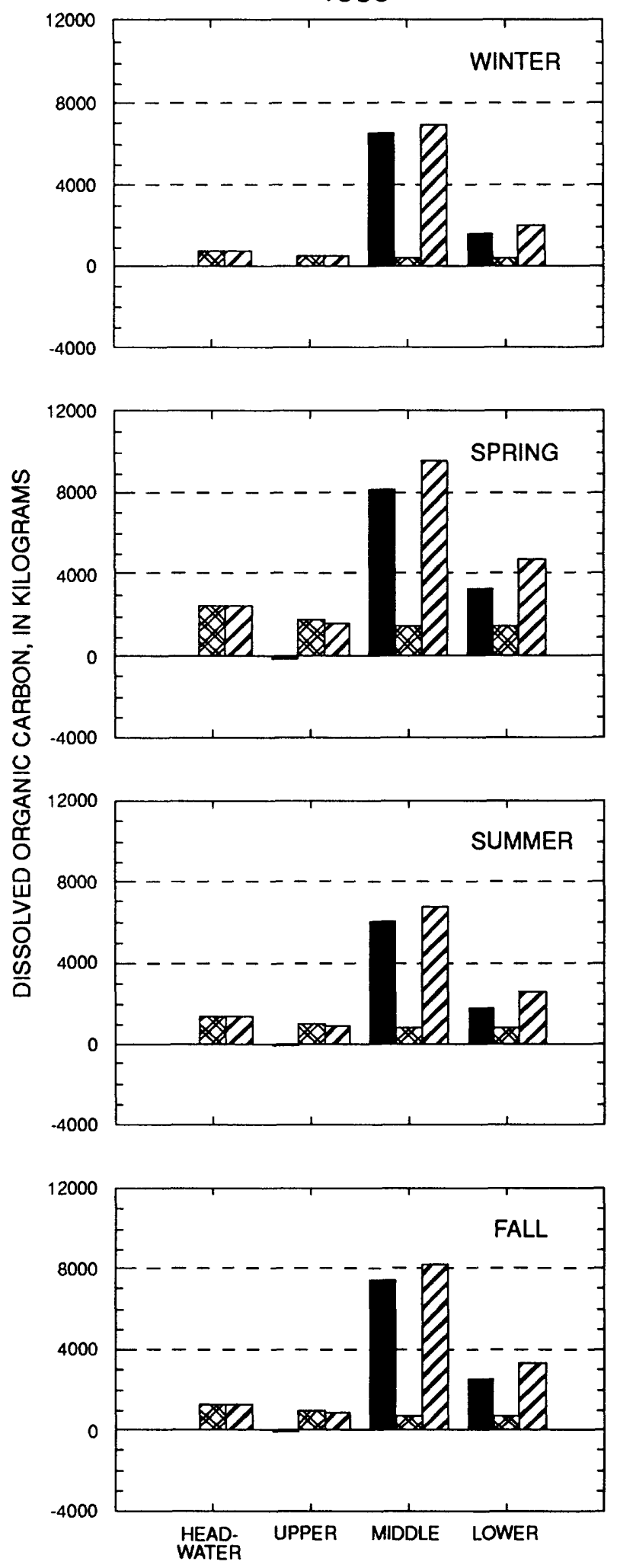

REACH

1986
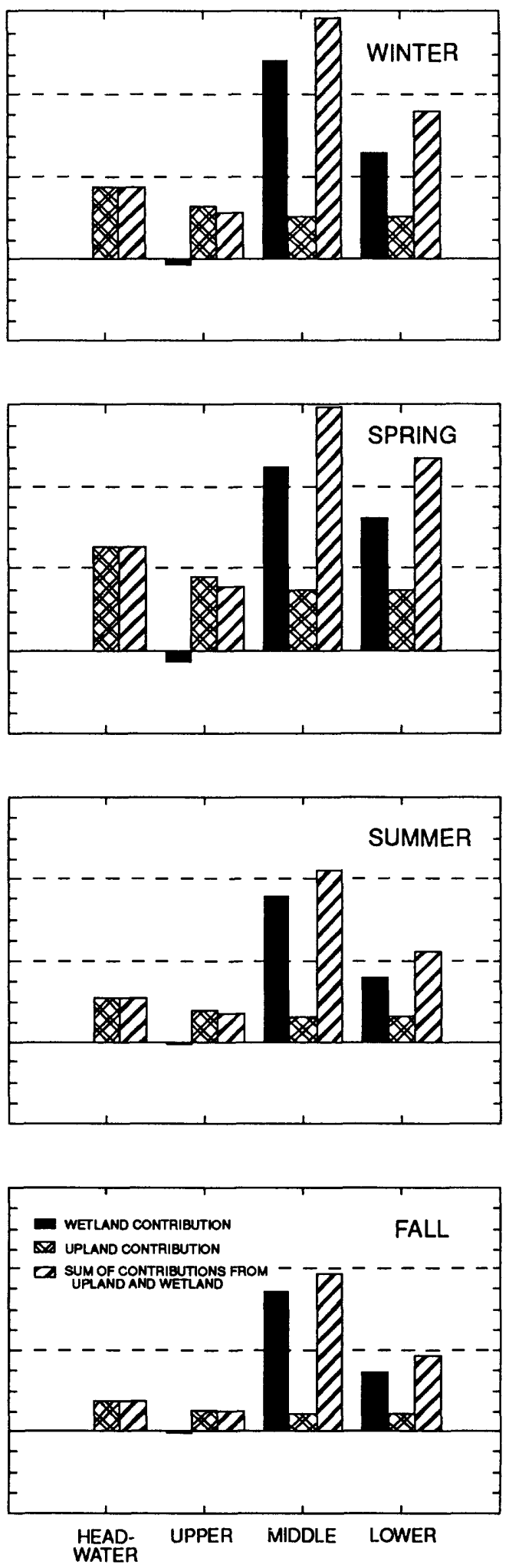

REACH

Figure 19.--Seasonal discharge of dissolved organic carbon, by individual stream reach, for Natty Pond Brook, Massachusetts, 1985 and 1986. 
Because stream water flowed more slowly through this reach, a given volume of water was subjected to the chemical discharge from peatwater over longer periods compared to the other reaches. The net effect is that residence time is inversely proportional to dilution; the slower the stream flows through a wetland reach, the greater will be the effect of wetland water chemistry.

Trends in discharges of suspended organic carbon from the wetland were somewhat different than trends of dissolved organic carbon. Figure 20 shows that suspended organic carbon was retained within both the upper and lower reaches. Only during the high flow periods in 1986 were yields within the upper reach positive (approximately 50 and $150 \mathrm{~kg}$ in winter and spring, respectively). During the periods when suspended organic carbon was retained within the upper reach, the amounts were relatively small $(2 \mathrm{~kg}$ per season), rarely exceeding the amount of dissolved organic carbon retained (fig. 19). For the lower reach, suspended organic carbon was retained irrespective of season. The amounts of the constituent retained within the lower reach ranged from about 10 to $400 \mathrm{~kg}$ per season. Similar to the trend observed with dissolved organic carbon, wetland-derived discharges of suspended organic carbon from the middle reach were consistently positive and were the largest of the three wetland reaches (ranging from about 200 to $700 \mathrm{~kg}$ per season).

The upper reach, with relatively high concentrations of DO (table 3 ), discharged the smallest amounts of dissolved and suspended organic carbon. This may be explained partly by the relatively small wetland and partly because DO is available to oxidize organic carbon to carbon dioxide and water (eq. 4). By contrast, the middle reach had relatively small concentrations of oxygen, and the highest wetland-derived discharges of dissolved and suspended organic carbon. The large wetland of the middle reach serves as a source of organic material that is broken down by fermentation to form organic carbon (eq. 5). This process breaks down high-molecular-weight carbohydrates to soluble low-molecular-weight organic carbon by anaerobes.

In the lower reach, where oxygen concentrations are greater than those in than the middle reach, a slight decrease in dissolved and suspended organic carbon loads occurred, indicating that fermentation had less of an effect than it did in the middle reach, probably because of the shorter residence time in the lower reach compared to the middle reach.
The entire wetland increased dissolved organic carbon loads in the stream. Median concentrations of dissolved organic carbon were $4.3 \mathrm{mg} / \mathrm{L}$ at $\mathrm{Q} 1$ and 12.0 $\mathrm{mg} / \mathrm{L}$ at $\mathrm{Q4}$. Color, an indicator of the presence of organic acids, also increased as the stream flowed through the wetland. Between Q1 and Q4, median color values increased from 20 to $130 \mathrm{Pt}$-Co units and maximum color values increased from 55 to $500 \mathrm{Pt}$-Co units. Suspended organic carbon concentration in the stream remained fairly constant at a median of about $0.4 \mathrm{mg} / \mathrm{L}$ throughout the wetland.

In addition to the effects of wetland size and DO status, other geochemical processes can affect the amount of organic carbon transported by the various reaches of Natty Pond Brook. For example, adsorption of organic acids to complexed metals, such as aluminum and iron and adsorption to sediment surfaces, can cause some removal of dissolved organic carbon in streams (Thurman, 1985, p. 389).

\section{Hydrogen lon and Alkalinity}

Because of the large accumulation of organic acids in wetland systems, hydrogen ion is a significant indicator of wetland effects on water quality. As organic acids dissociate, hydrogen-ion concentrations increase. Organic material (peat), with its high cation-exchange capacity, may exchange its hydrogen for metal ions (for example, $\mathrm{Ca}^{2+}, \mathrm{Mg}^{2+}, \mathrm{Na}^{+}, \mathrm{K}^{+}$), thereby releasing hydrogen ions to wetland water (Weider, 1985, p. 298). Hydrogen ions can be either consumed or produced in the degradation of organic material and the nitrification of ammonium. Hydrogen-ion concentrations can have important effects on other chemical constituents. For example, as hydrogen-ion concentrations decrease, organic acids that were complexed with metals and the metals will be removed from solution.

The upper reach consistently retained hydrogen ion and yielded alkalinity (table 9 and figs. 21 and 22). Although hydrogen-ion retention varied with flow from about 0.5 to $3.5 \mathrm{~kg}$ per season, the discharge of alkalinity was nearly constant at $2,000 \mathrm{~kg}$ (as calcium carbonate) per season. The consumption of hydrogen ions in this reach is sufficient to cause a rise in $\mathrm{pH}$ levels (table 3 ) and an increase in bicarbonate ion, as carbonic acid dissociates to satisfy carbonate equilibrium, as follows:

$$
\mathrm{H}_{2} \mathrm{CO}_{3}=\mathrm{H}^{+}+\mathrm{HCO}_{3}^{-}
$$


1985
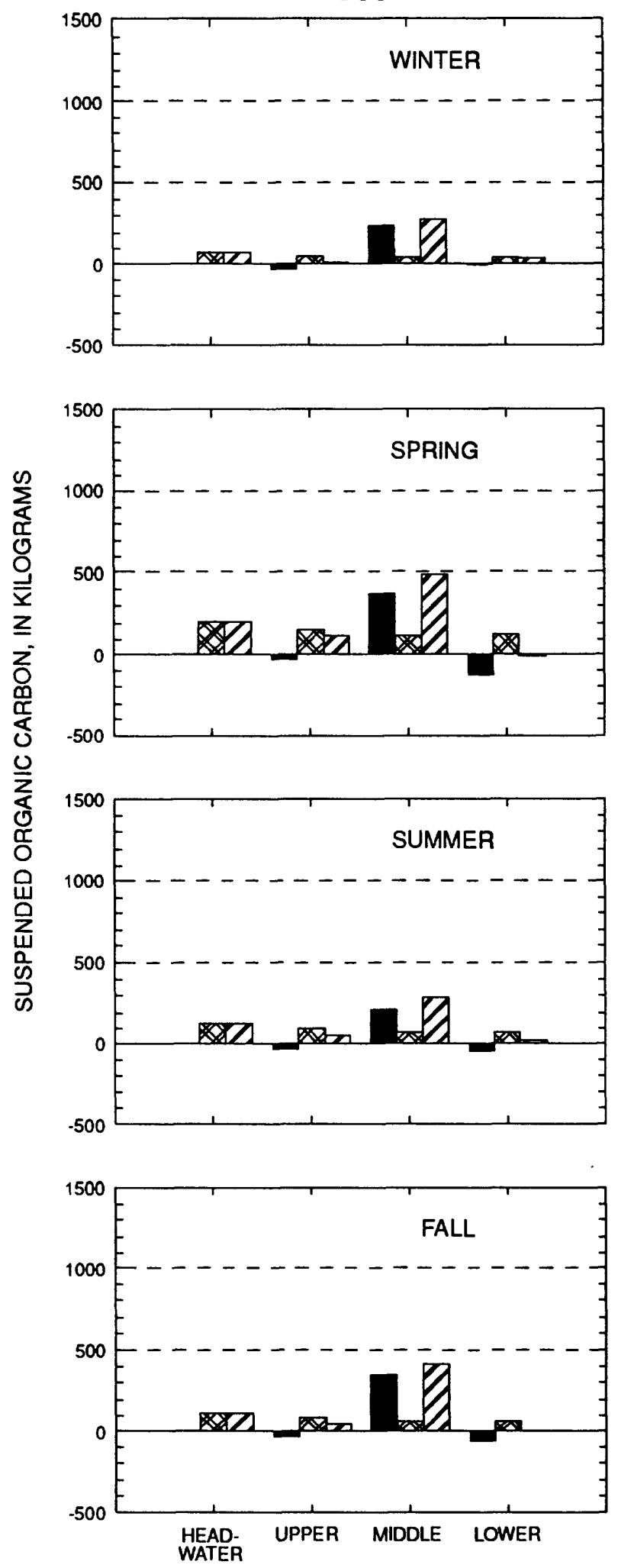

REACH
1986
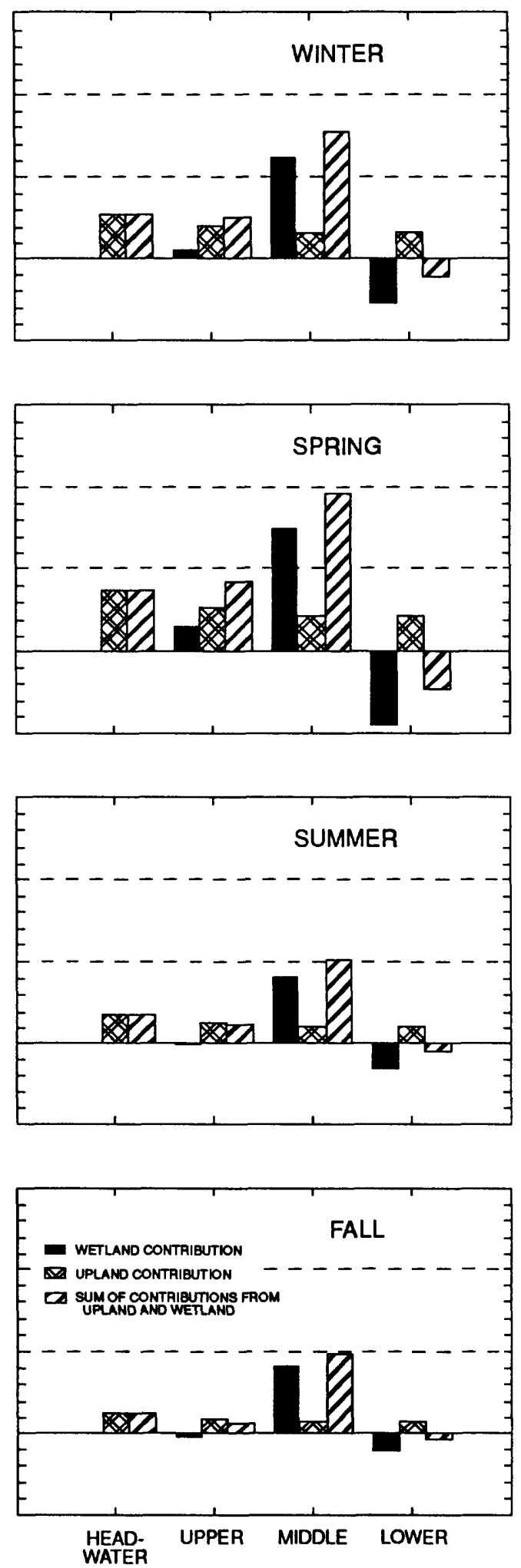

REACH

Figure 20.--Seasonal discharge of suspended organic carbon, by individual stream reach, for Natty Pond Brook, Massachusetts, 1985 and 1986. 
At pH levels about 6.4, the forward reaction is favored (Manahan, 1975, p. 26). Therefore, the increase in alkalinity within the upper reach occurs as the carbonate equilibrium shifts, probably in response to hydrogen-ion consumption by aerobic degradation of organic matter (ammonification).

The middle reach typically yielded about $0.5 \mathrm{~kg}$ hydrogen ions per season, with the highest yields occurring during low-flow conditions. The alkalinity yields ranged from about $500 \mathrm{~kg}$ in the summer to slightly more than $2,000 \mathrm{~kg}$ in the spring. Increased yields of hydrogen ion through this reach are probably related to the size of the wetland that serves as a source of organic material and organic acids. The release of hydrogen ions in this reach is sufficient to cause a decline in $\mathrm{pH}$ from 6.26 to 5.78 . As $\mathrm{pH}$ decreases, the backward reaction shown by eq. 6 is favored; the hydrolysis of bicarbonate causes alkalinity discharge to decrease. Therefore, the small alkalinity yield within the middle reach relative to the upper reach occurs as the carbonate equilibrium shifts in response to hydrogen-ion release from organic-acid dissociation and from cation exchange.

The greatest hydrogen ion yield was from the lower reach-about $1 \mathrm{~kg}$ during low-flow conditions and nearly $2 \mathrm{~kg}$ during high-flow conditions. Hydrogen ions may be released from organic-acid dissociation and from cation exchange in peat. Alkalinity in this reach was consistently retained; retention ranged from 750 to $1,500 \mathrm{~kg}$ per season. Most of the alkalinity load was retained during high-flow conditions. This trend is the inverse of the trend described for hydrogen ion. It seems that the release of hydrogen ions causes alkalinity loads to decrease to satisfy carbonate equilibrium.

The differences in the amount of hydrogen ion transported from the three wetland reaches seem to relate to the degradation reactions that are most favored in each reach. Release of hydrogen ions in the middle and lower reaches would be expected to cause significant decreases in $\mathrm{pH}$. However, $\mathrm{pH}$ remained above 5.0 and increased slightly through the wetland (table 3). Median $\mathrm{pH}$ values were 5.66 at $\mathrm{Q} 1,6.26$ at $\mathrm{Q} 2,5.78$ at $\mathrm{Q3}$, and 5.86 at $\mathrm{Q4}$. Some of the hydrogen ion was consumed in the carbonate equilibrium reactions. Other reactions that may likely consume hydrogen ion through the wetland involve chemical reducing agents, such as iron.
Iron

Iron in wetland areas may be in either the soluble or insoluble form depending mostly on $\mathrm{pH}$ and oxygen concentration in the waters. Under aerobic conditions, soluble ferrous iron $\left(\mathrm{Fe}^{2+}\right)$ is unstable and readily oxidizes to ferric iron $\left(\mathrm{Fe}^{3+}\right)$, forming insoluble hydrated iron oxide, as follows:

$$
\left.4 \mathrm{Fe}^{2+}+\mathrm{O}_{2}+10 \mathrm{H}_{2} \mathrm{O}=4 \underline{\mathrm{Fe}(\mathrm{OH}}\right)_{3}+8 \mathrm{H}^{+}
$$

Under anaerobic conditions, iron may be present as a stable, soluble species (Manahan, 1975, p. 41). In its reduced form, iron can reach toxic concentrations for biota in wetland soils. Near the root surfaces of wetland plants, the ferrous ion can readily become oxidized by oxygen leaking from root cells to form hydrous ferric oxide. This insoluble oxide can coat the roots, creating a barrier to nutrient uptake.

The upper reach, with relatively high concentrations of DO (table 3), yielded about three times as much total iron as dissolved iron (passed through 0.45 micrometer filter) (figs. 23 and 24). The middle reach yielded the greatest amount of iron of the three reaches ( 800 to $1,050 \mathrm{~kg}$ per season). About 90 percent of that iron was in a soluble or colloidal form (passed the filter) probably because of the relatively low DO concentrations and the excess hydrogen-ion concentrations. Much of the excess hydrogen ion released from the middle reach may be consumed in the reduction of iron oxide to soluble ferrous ions (eq. 7). This helps explain why $\mathrm{pH}$ levels did not decline as greatly as expected in the middle reach (table 3 ).

In the lower reach, where oxygen concentrations are higher than in the middle reach, iron was oxidized to insoluble forms and retained or transported in suspension. The lower reach generally retained dissolved iron (ranging from about 50 to $200 \mathrm{~kg}$ per season), but yielded small amounts (from about 50 to $300 \mathrm{~kg}$ per season) of iron in the insoluble form. Because this reach yielded dissolved iron during high flows, there was an approximate balance between annual dissolved iron import and export.

The entire wetland contributed large gains in iron concentrations to the stream. In general, most of the iron was in the soluble form (passed through a 0.45 micrometer filter). Median concentrations of dissolved iron were $120 \mu \mathrm{g} / \mathrm{L}$ at $\mathrm{Q} 1$ and $1,010 \mu \mathrm{g} / \mathrm{L}$ at Q4. 
1985

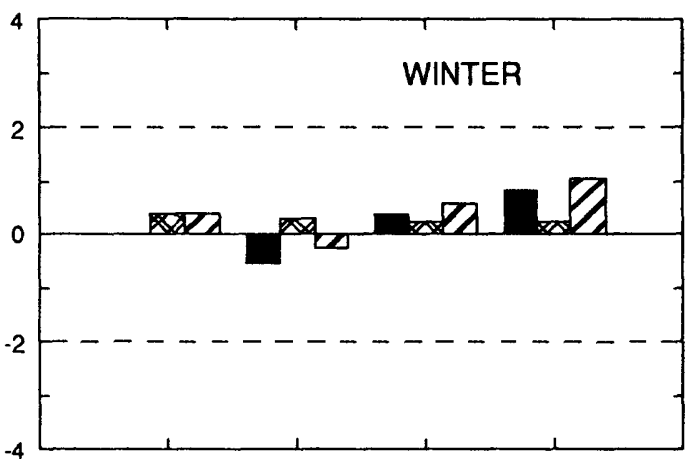

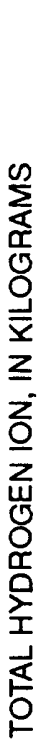
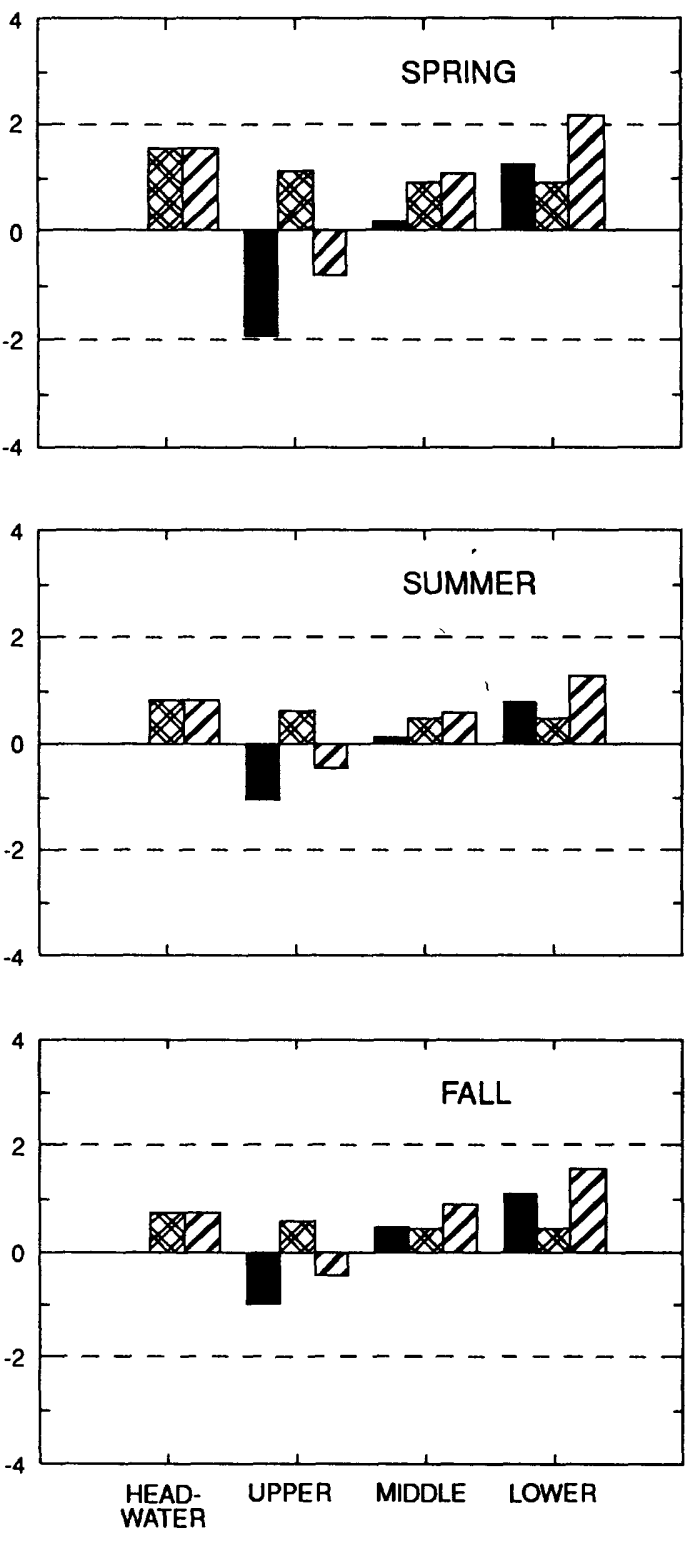

REACH
1986
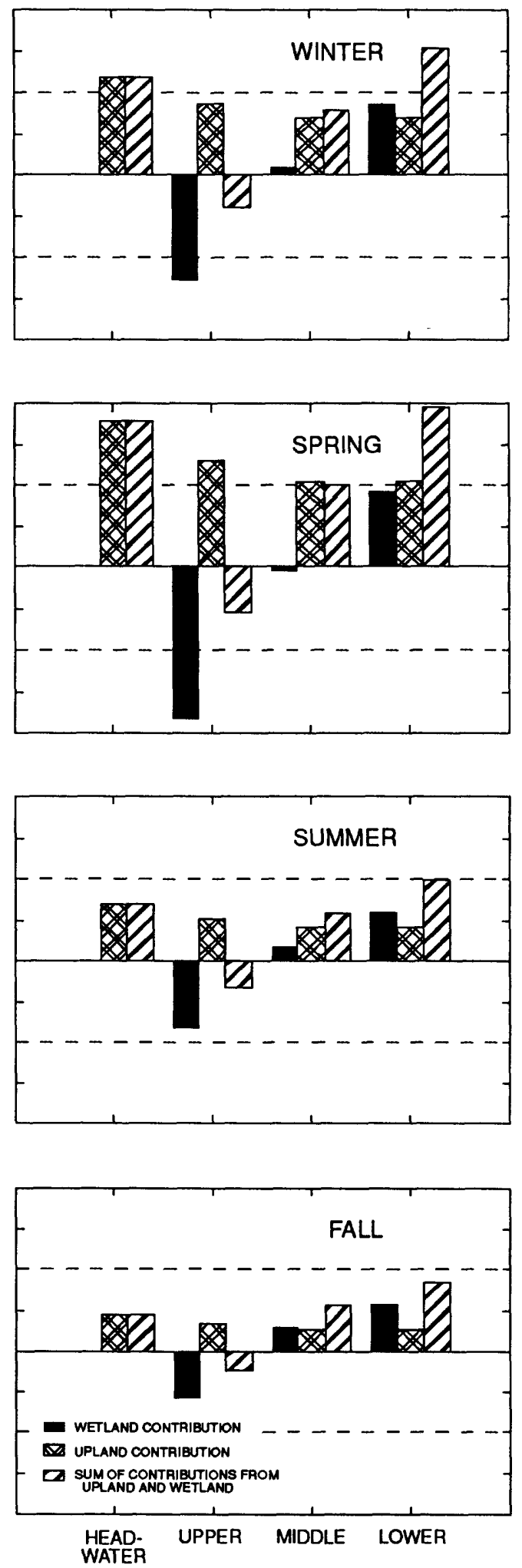

REACH

Figure 21.--Seasonal discharge of total hydrogen ion, by individual stream reach, for Natty Pond Brook, Massachusetts, 1985 and 1986. 
1985
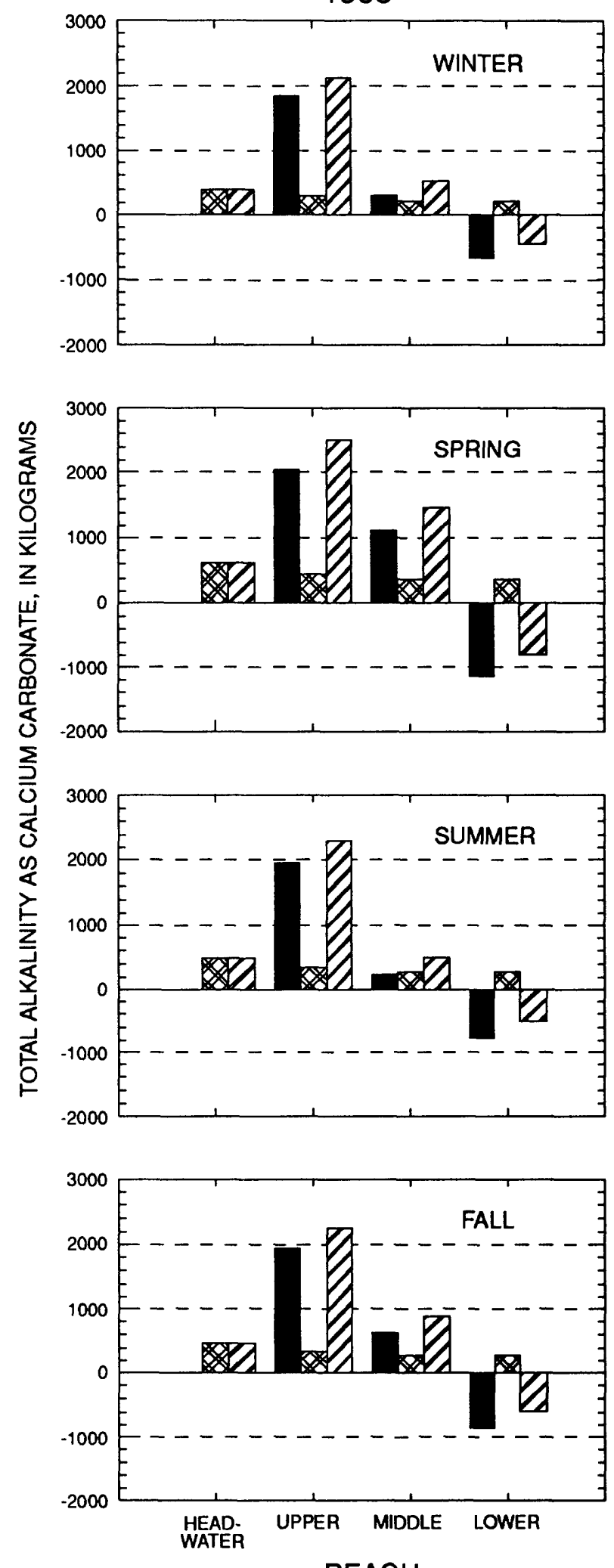

1986
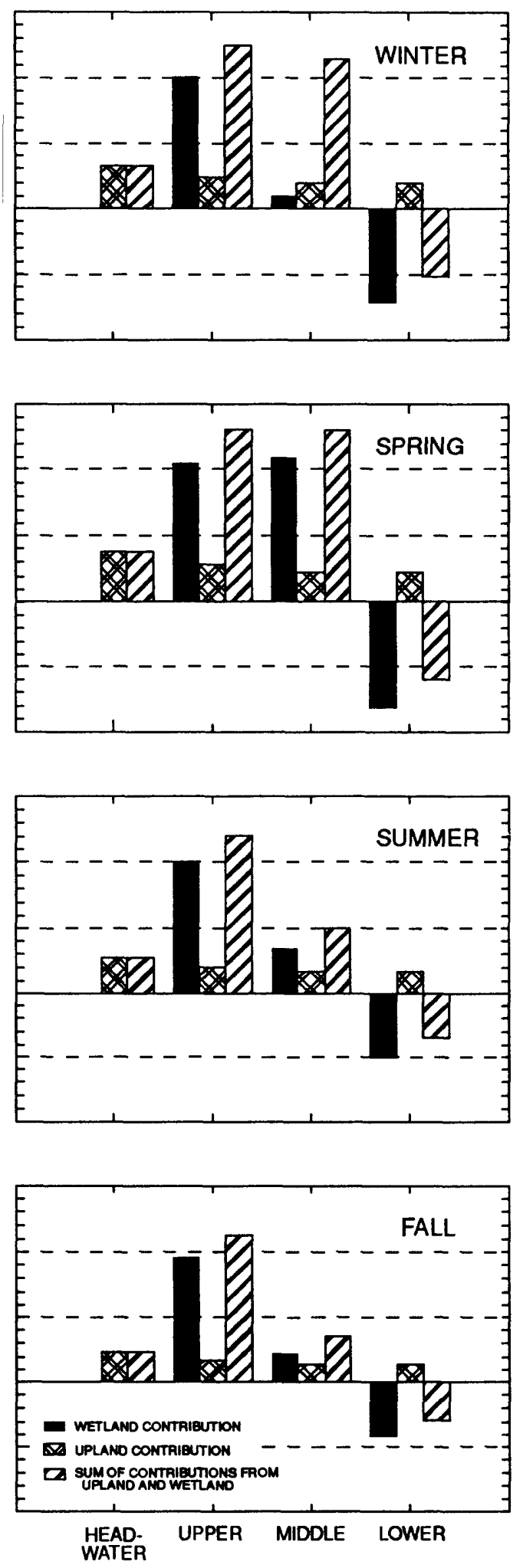

REACH

Figure 22.--Seasonal discharge of total alkalinity as calcium carbonate, by individual stream reach, for Natty Pond Brook, Massachusetts, 1985 and 1986. 
1985
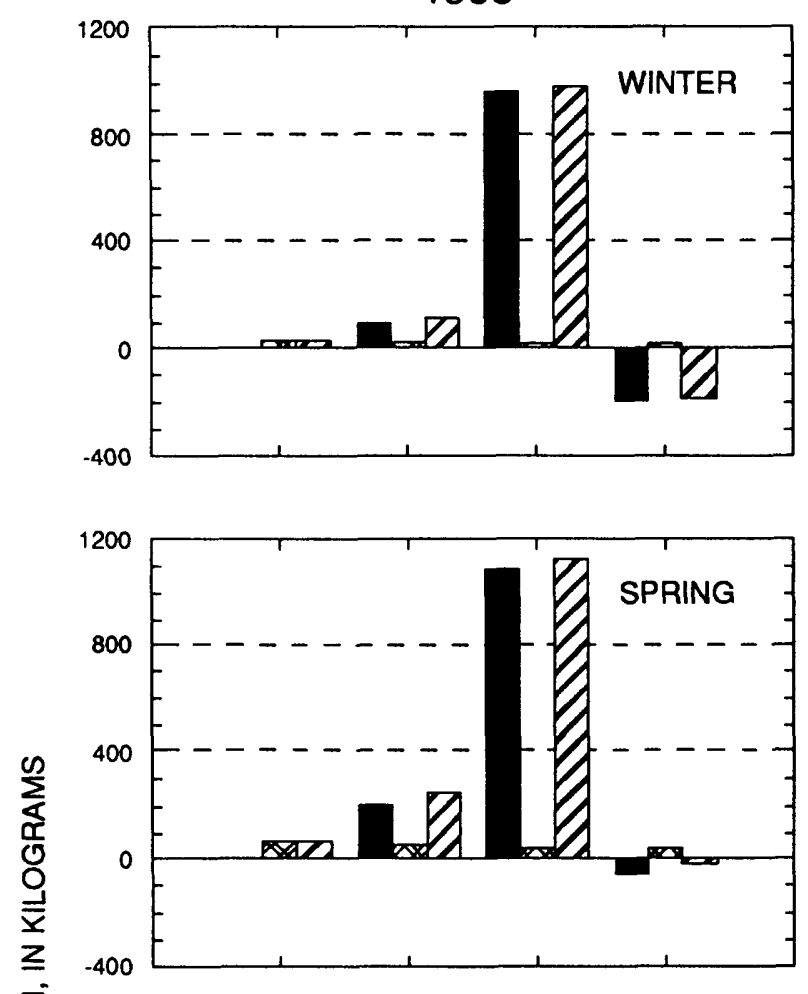

Zั

Ð
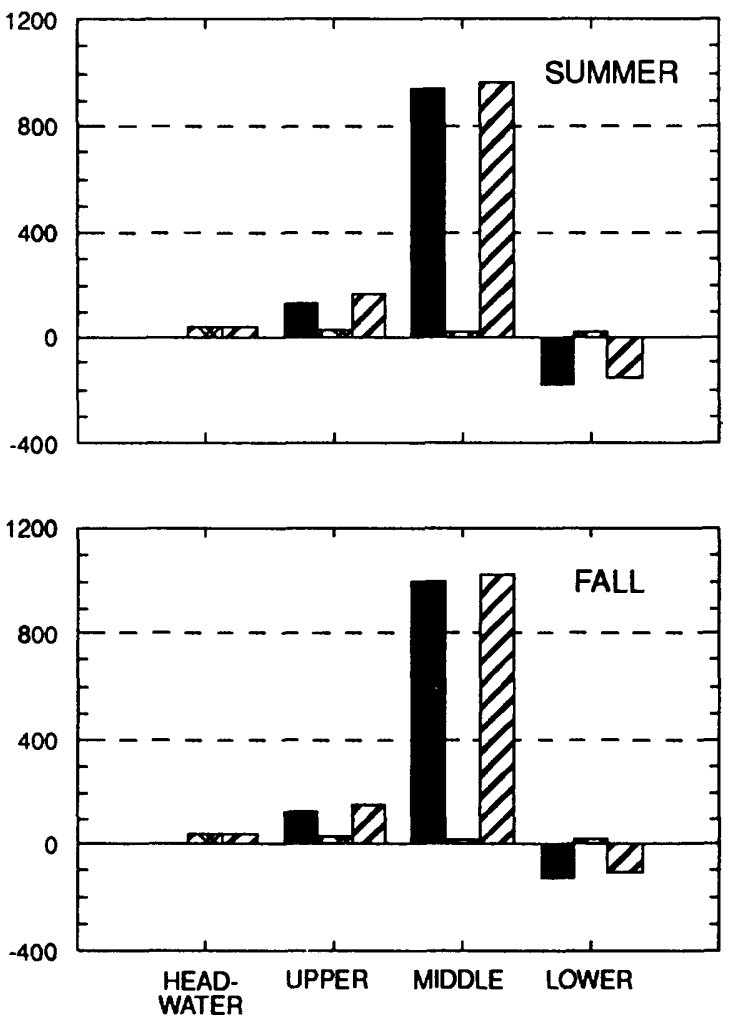

REACH
1986
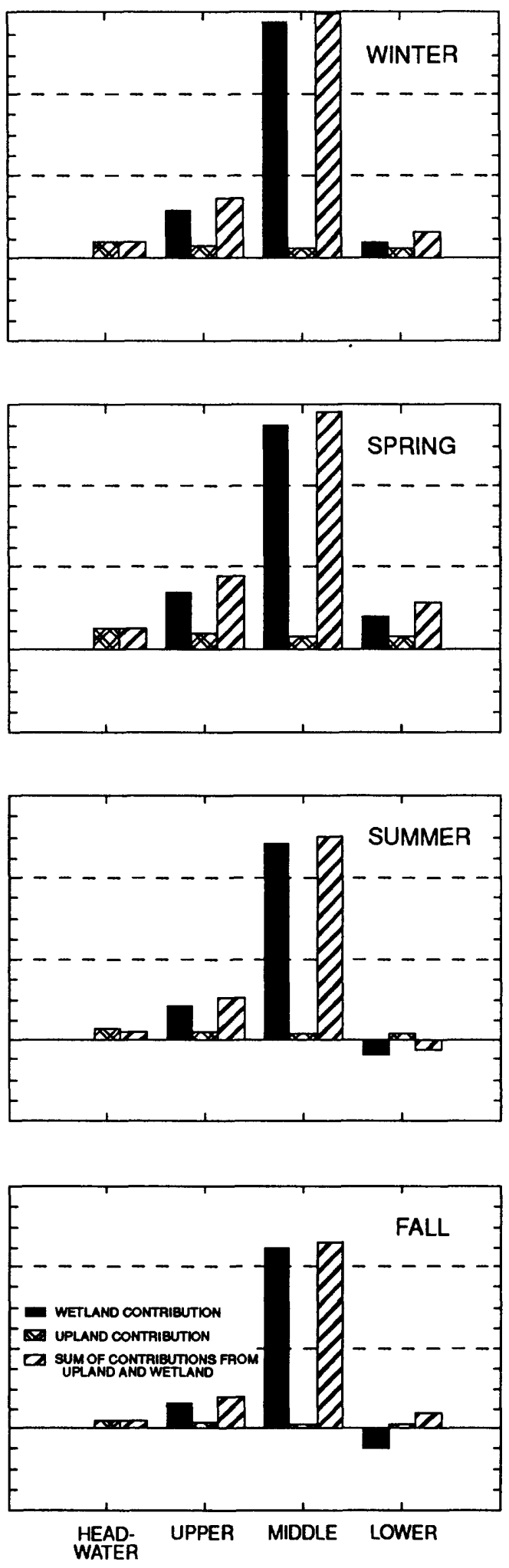

$\mathrm{REACH}$

Figure 23.--Seasonal discharge of dissolved iron, by individual stream reach, for Natty Pond Brook, Massachusetts, 1985 and 1986. 
1985
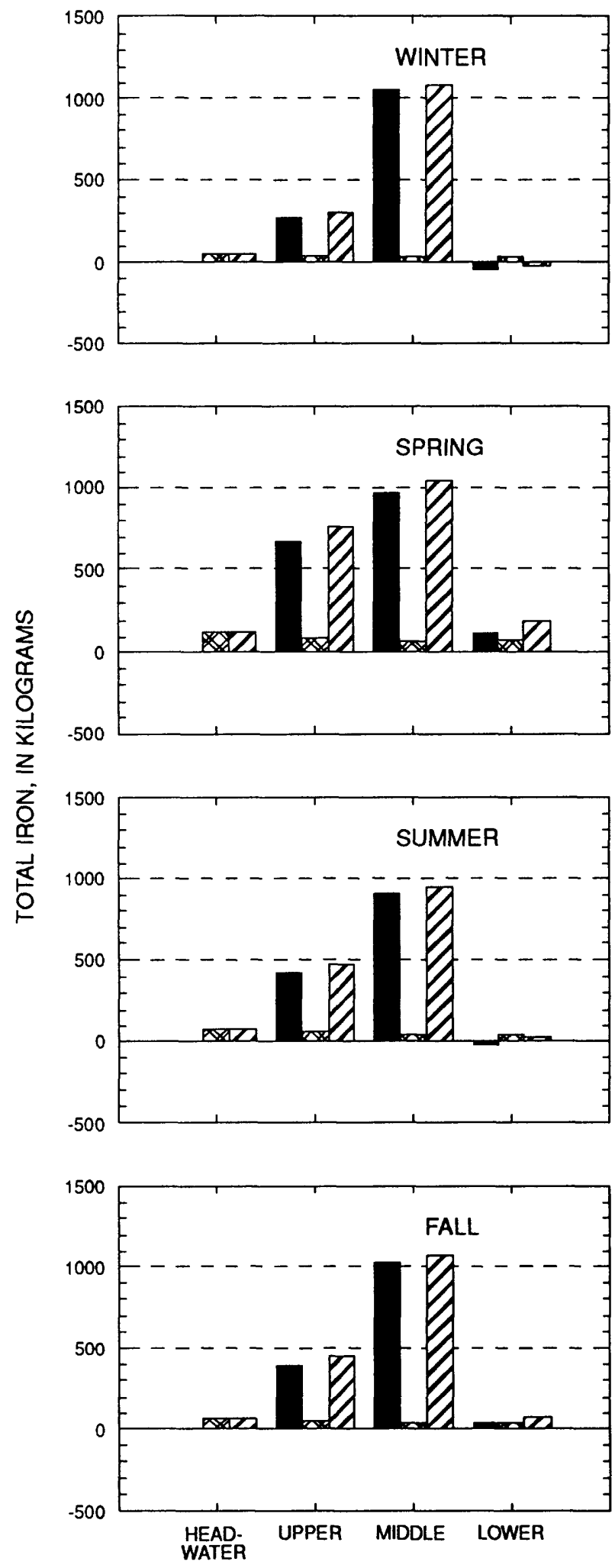

REACH
1986
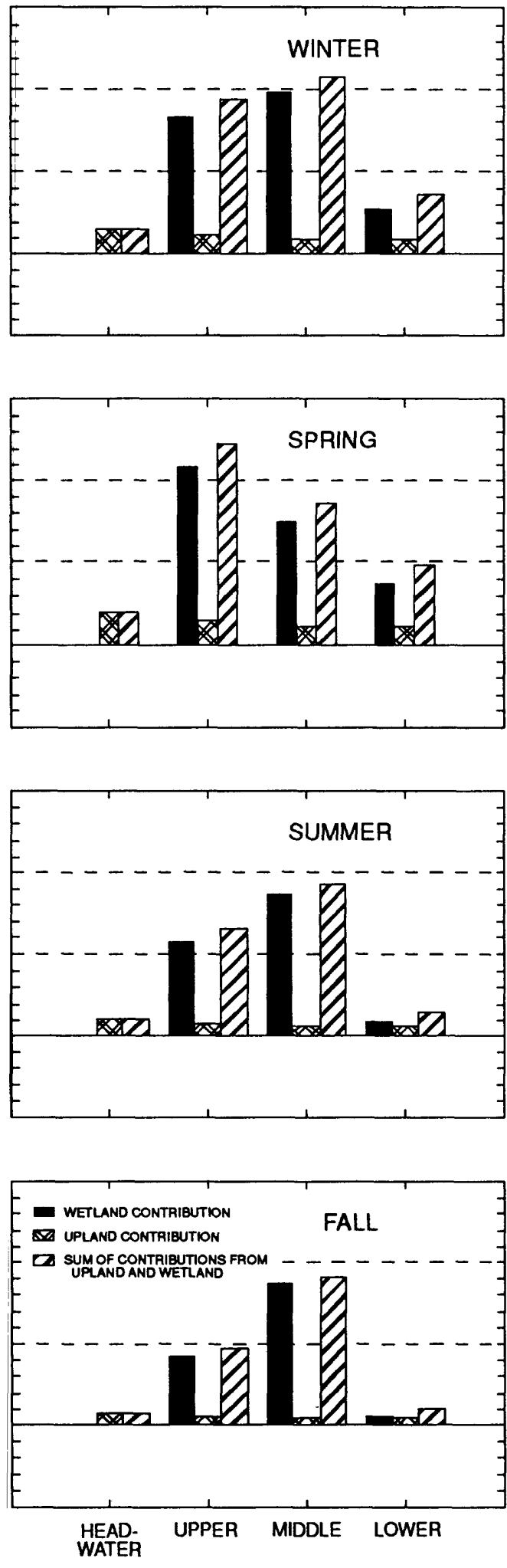

REACH

Figure 24.--Seasonal discharge of total iron, by individual stream reach, for Natty Pond Brook, Massachusetts, 1985 and 1986. 


\section{Aluminum}

Ionic aluminum is an undesirable constituent in water because it is toxic to many species of aquatic life. At concentrations as low as a few milligrams per liter, $\mathrm{Al}^{3+}$ can cause drastic changes in aquatic biota populations and can even cause loss of fisheries. Wetland water, with high concentrations of organic acids, commonly contains higher concentrations of aluminum than other waters. However, the aluminum in wetlands water is generally complexed with the organic acids, making it unavailable in the toxic ionic form.

The geochemistry of aluminum in wetland waters depends on $\mathrm{pH}$. Above a pH of about 4.0, soluble aluminum readily loses hydrogen, as follows:

$$
\mathrm{Al}\left(\mathrm{H}_{2} \mathrm{O}\right)_{6}{ }^{3+}=\mathrm{Al}(\mathrm{OH})\left(\mathrm{H}_{2} \mathrm{O}\right) 5^{2+}+\mathrm{H}^{+}
$$

In the $\mathrm{pH}$ range of 4.5 to 6.5 , hydrolysis occurs, ending with the precipitation of microcrystalline gibbsite, $\mathrm{Al}_{2} \mathrm{O}_{3} \cdot \mathrm{H}_{2} \mathrm{O}$ (Nordstrom and Ball, 1986, p. 55).

In the upper reach, dissolved aluminum was consistently retained (fig. 25). The greatest retention within this reach occurred during the high-flow periods of spring 1985, and winter and spring 1986 (approximately 50 to $60 \mathrm{~kg}$ per season). With median $\mathrm{pH}$ approaching 6.30, and a maximum value of 6.56 (table 3 ), it appears that aluminum is mainly in the microcrystalline form in this reach.

pH declined in the middle and lower reaches (median values 5.78 and 5.86, respectively) and yields of dissolved aluminum increased. Discharge of dissolved aluminum ranged from 30 to $50 \mathrm{~kg}$ per season in the middle reach and 20 to $70 \mathrm{~kg}$ per season in the lower reach. Insoluble aluminum from the upper reach may be converted to a soluble form in the middle and lower reaches.

The entire wetland contributed negligible gains in dissolved aluminum concentrations to the stream. Median concentrations were $115 \mu \mathrm{g} / \mathrm{L}$ at $\mathrm{Q} 1$ and 130 $\mu \mathrm{g} / \mathrm{L}$ at $\mathrm{Q4}$. The presence of organic acids and the occurrence of $\mathrm{pH}$ values above 5.0 seem to keep aluminum in the complexed or microcrystalline forms.

Differences in $\mathrm{pH}$ and dissolved metals concentrations can have indirect effects on other constituents. For example, the amount of organic carbon transported from the various reaches of Natty Pond Brook followed the general trend of dissolved alumi- num through the system. In the upper reach, retention of both aluminum and organic carbon was fairly consistent. Organic material commonly adsorbs to complexed metals such as aluminum, thereby allowing the metal to have a scavenging effect on the organic carbon. When $\mathrm{pH}$ increases and causes complexed aluminum to precipitate, organic-carbon concentrations also decline (Thurman, 1985, p. 389). Although concentrations of aluminum in the stream that flows through the wetland were at least one order of magnitude less than organic carbon concentrations, aluminum can have a minor scavenging effect on organic carbon. In the upper reach, in which dissolved aluminum concentration decreased, organic carbon also decreased slightly. In reaches that yielded dissolved aluminum, organic carbon yields also increased. Changes in $\mathrm{pH}$ and aluminum also may have a similar effect on other constituents, such as phosphorus.

\section{Phosphorus}

Phosphorus is an important nutrient in aquatic habitats. Phosphorus is considered a major cause of eutrophication in freshwater bodies, because this nutrient is often in the shortest supply and tends to control plant production. Domestic and industrial sewage effluents and fertilizer runoff can be major sources of phosphorus in surface waters. In addition, the decay and mineralization of organic materials transform organic molecular phosphorus to inorganic orthophosphate, which is the form considered to be the most biologically available to plants. Phosphorus loading can be indirectly affected by metals. Under aerobic conditions, phosphorus sorbed to aluminum and iron complexes can be precipitated along with the metal. When conditions become anaerobic, the hydrolysis of ferric and aluminum phosphates can release the bound phosphorus (Mitsch and Gosselink, 1986, p. 106).

The upper reach showed a fairly consistent retention of hydrolyzable-plus-orthophosphate phosphorus (ranging from about 5 to $20 \mathrm{~kg}$ per season (fig. 26). The middle reach discharged the largest amount of wetland-derived hydrolyzable-plus-orthophosphate phosphorus--about 20 to $30 \mathrm{~kg}$ per season.

The entire wetland slightly increased phosphorus concentrations to the stream. Between $Q 1$ and Q4, median concentrations of hydrolyzable-plus-orthophosphate phosphorus only increased from $<0.01$ 
1985
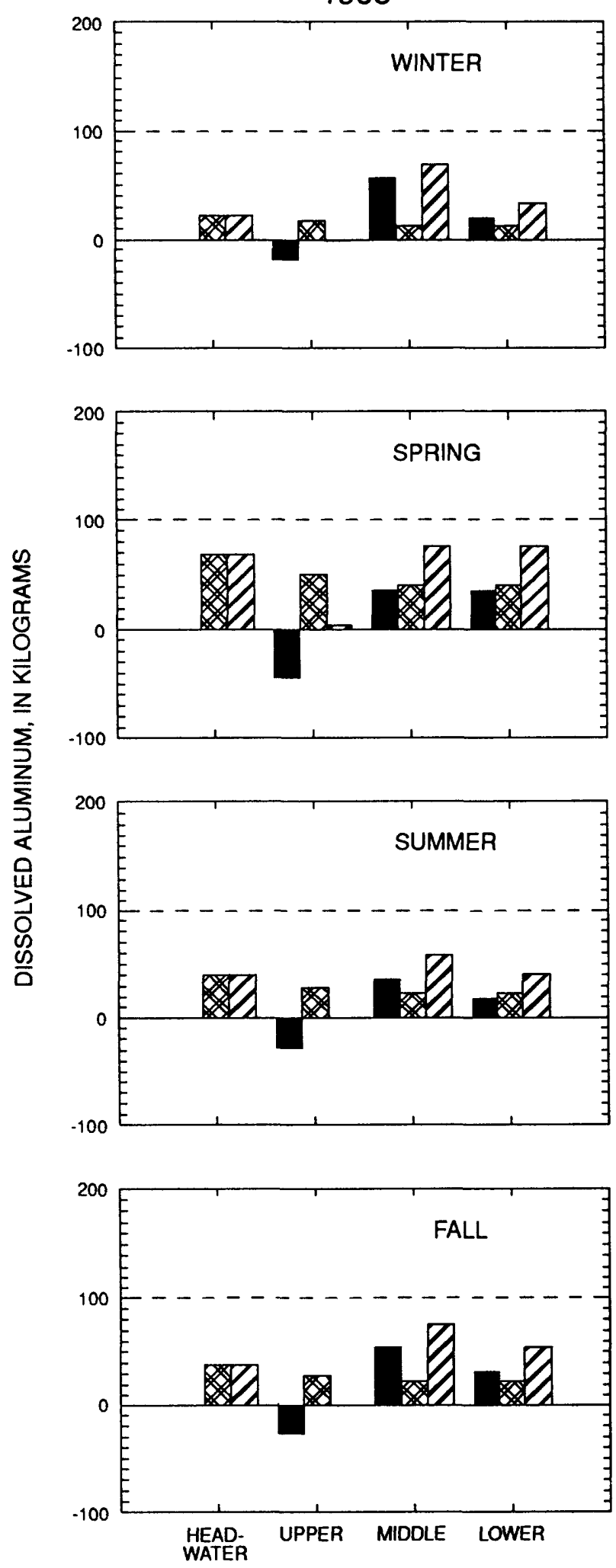

REACH
1986
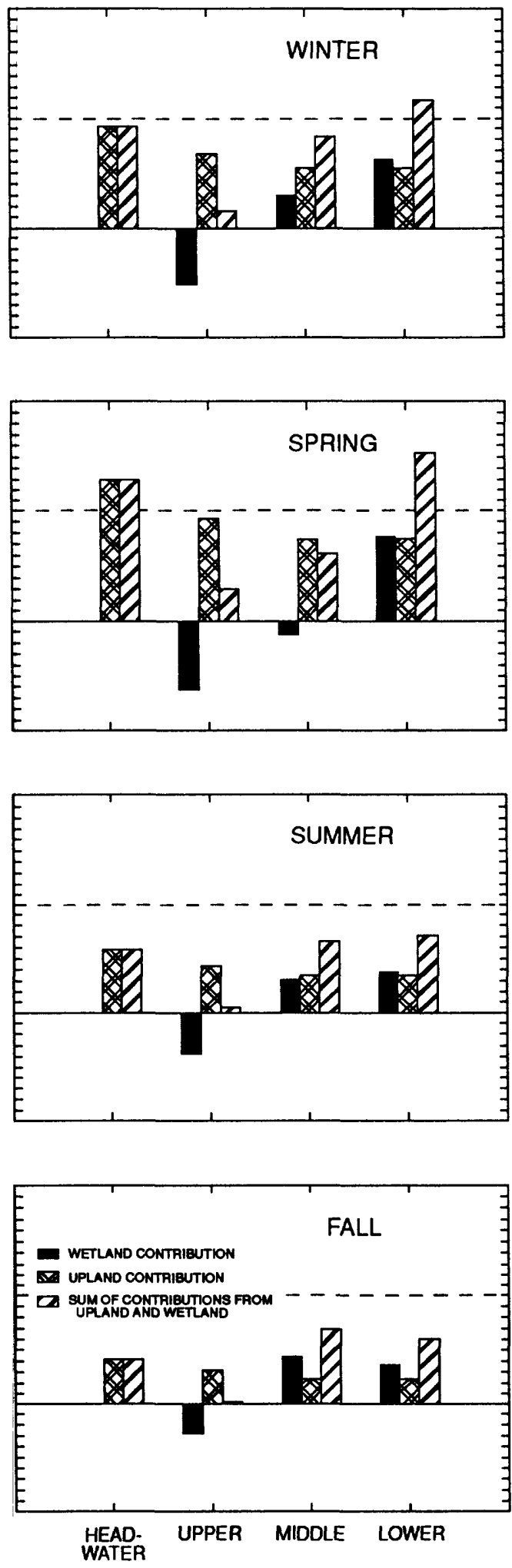

REACH

Figure 25.--Seasonal discharge of dissolved aluminum, by individual stream reach, for Natty Pond Brook, Massachusetts, 1985 and 1986. 


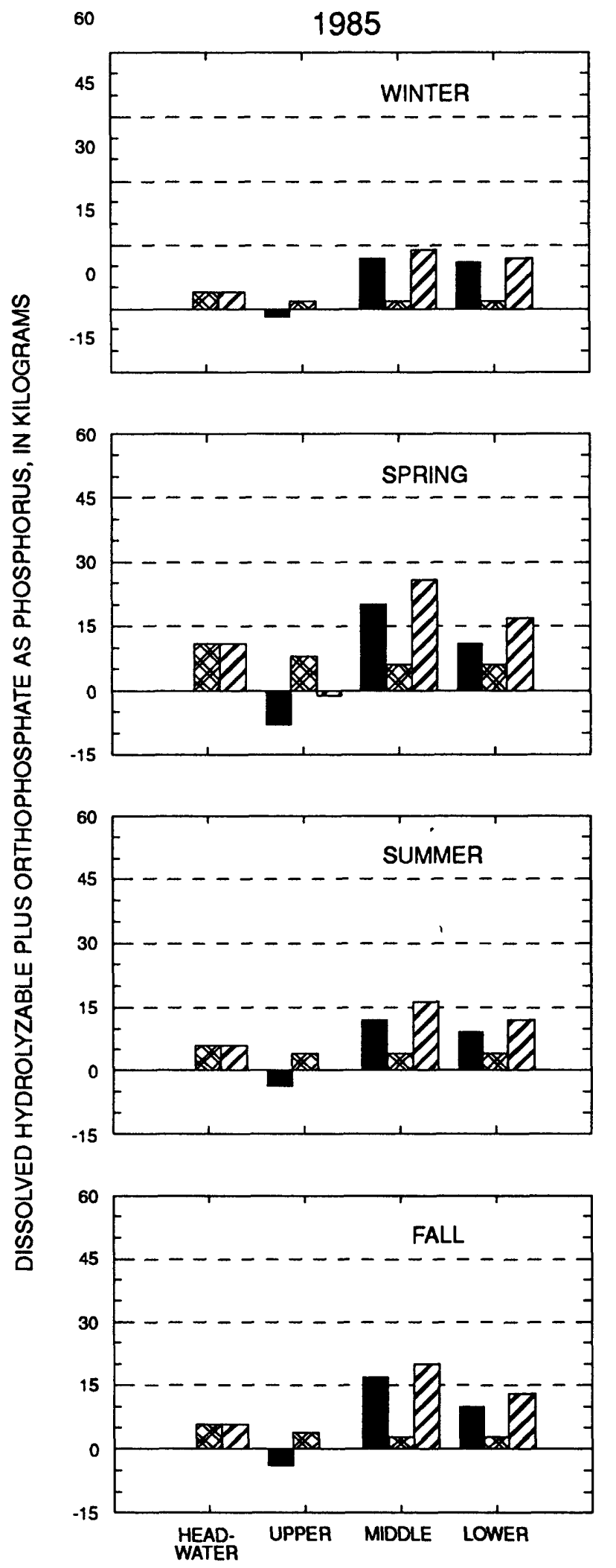

REACH
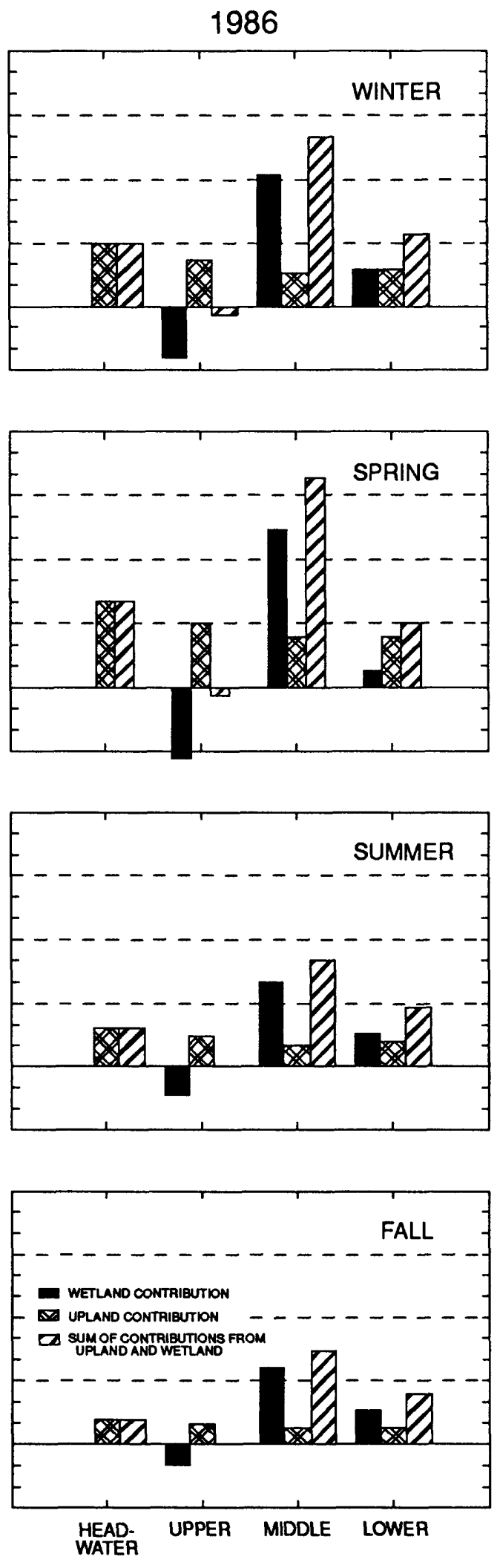

REACH

Figure 26.--Seasonal discharge of dissolved hydrolyzable plus orthophosphate as phosphorus, by individual stream reach, for Natty Pond Brook, Massachusetts, 1985 and 1986. 
to $0.03 \mathrm{mg} / \mathrm{L}$. The net effect of the wetland on the inorganic phosphorus content of Natty Pond Brook was small. During periods of high flow, the increase in water volume was relatively greater than the decrease in phosphorus concentrations caused by dilution, so that increases in flow caused increases in loads. However, concentrations remained within a fairly small range, even during low-flow periods. Furthermore, no increased retention of phosphorus from the stream was observed during the growing season. Because the stream entering the wetland contained only low concentrations of phosphorus, the ability of the wetland to assimilate concentrations of phosphorus that might be caused by a wastewater discharge or by agricultural runoff was not tested.

\section{SUMMARY}

The stream-side wetland was shown to affect the hydrology of Natty Pond Brook. Water balances for the nearly 200 -ha wetland showed annual precipitation of 1,010 and $1,020 \mathrm{~mm}$, upland surface- and ground-water inputs of 2,060 and $3,640 \mathrm{~mm}$, surfacewater runoffs of 2,420 and $3,910 \mathrm{~mm}$, and evapotranspiration of 570 and $550 \mathrm{~mm}$, respectively, in the 1985 and 1986 study years. Error residuals of 65 and 230 $\mathrm{mm}$ for the 2 years were within the limits of measurement techniques, but most likely represent underestimates of evaportranspiration. The 1-year periods selected for computation of the budgets yielded the minimal changes in storage of $22 \mathrm{~mm}$ in 1985 and 30 $\mathrm{mm}$ in 1986.

Seasonal variations showed the importance of the effect of evapotranspiration on wetland stream hydrology. During the spring and summer growing seasons of both years, the middle wetland reach consumed more water than it contributed to the stream. During the spring of 1986 , the wetland as a whole contributed virtually no flow to the stream. Although wetlands have the capacity to store flood flows, they consume water through evapotranspiration during warm weather low-flow periods.

Wetland hydrology and wetland hydrochemical processes combine to cause seasonal variations in stream-water quality. During periods of high flow, the increase in water volume was relatively greater than the decrease in constituent concentrations caused by dilution, so that all increases in flow, regardless of season, caused increases in constituent loads to the stream. During high flow periods, contributions from upland areas often accounted for a large portion of the total stream load. During low-flow periods, even though certain water-quality constituents became concentrated, the decrease in water volume caused constituent loads to be less than those observed during high-flow periods. However, the wetland became a significant contributor to the stream loading, because wetland-derived loads represented a large percentage of the total stream load. Inflow to the wetland as precipitation, upland inflow, and ground-water discharge displaced water from the peat into the stream. Constituents associated with peatwater chemistry, such as dissolved organic carbon, hydrogen ion, dissolved iron, ammonium nitrogen, and phosphorus increased wetland-derived loads relative to total stream load. Processes occurring within the wetland, such as production of soluble organic materials, leaching of nutrients liberated from peat mineralization, and cation exchange within peat, are the likely causes of the increased wetland contribution to stream loads during low-flow periods. These increased loads, in turn, depressed DO concentrations in the stream.

During 1985, the wetland discharged a total of $37,025 \mathrm{~kg}$ (a yield of $185 \mathrm{~kg} / \mathrm{ha}$ ) of organic carbon, $5,800 \mathrm{~kg}$ (a yield of $29 \mathrm{~kg} / \mathrm{ha}$ ) of dissolved iron, $664 \mathrm{~kg}$ (a yield of $3.3 \mathrm{~kg} / \mathrm{ha}$ ) of dissolved nitrogen, and $84 \mathrm{~kg}$ (a yield of $0.42 \mathrm{~kg} / \mathrm{ha}$ ) of dissolved phosphorus. During 1986, discharges of dissolved iron and nutrients from the wetland increased; discharges of organic carbon, iron, nitrogen, and phosphorus were 49,$180 ; 7,200$; 1,444 and 94 , (yields were $246 ; 36 ; 7.2$ and $0.47, \mathrm{~kg} / \mathrm{ha}$ ), respectively.

Characteristics showing the greatest relation to constituent loads were the amount of available DO, the size of the contributing wetland area, and the residence time of water in the stream reach. DO concentrations in the stream affected load transport because the availability of oxygen governs the biochemical processes that modify the chemical composition of some constituents. Wetland size had a significant effect on stream loads of organic carbon because wetland areas serve as source areas of organic material. Residence time of stream water played an important role in determining the water-quality character of the stream by governing the period over which the stream receives drainage from organic peat. For example, stream loads of dissolved organic carbon and dissolved iron were proportional to residence time; the longer the stream received water from the wetland, the greater the loads became. Consequently, the concentration of $\mathrm{DO}$, which is consumed by chemical reaction with organic carbon and iron, was inversely 
proportional to residence time. In addition, prolonged interaction facilitated the biochemical transformation of some water-quality constituents. For example, during the growing season, nutrients were used by wetland vegetation and microbes at a greater rate than their rate of input from incoming streamflow. Even for nongrowing periods, a slow rate of renewal facilitated the interaction of stream water with vegetal detritus and shallow ground water that had been in contact with the organic peat. Water-quality constituents associated with organic material were concentrated during the long contact time of water with the detritus and peat.

The upper reach of Natty Pond Brook is characterized by high DO concentrations, a small contributing wetland area, and a long stream residence time. Wetland areas in the upper reach typically yielded alkalinity and relatively small amounts of other constituents. The upper reach often retained constituents, including hydrogen ion, dissolved organic carbon, dissolved aluminum, and hydrolyzable-plusorthophosphate phosphorus. Discharges of alkalinity as calcium carbonate from the upper reach remained about $2,000 \mathrm{~kg}$ per season throughout the study period. Retention of dissolved organic carbon ranged from about 5 to $500 \mathrm{~kg}$ per season; hydrogen ion, 0.5 to $3.5 \mathrm{~kg}$ per season; aluminum, 20 to $60 \mathrm{~kg}$ per season; and hydrolyzable-plus-orthophosphate phosphorus, 5 to $20 \mathrm{~kg}$ per season. Nitrite-plus-nitrate nitrogen discharges were usually less than that from direct precipitation on the upper reach. Small yields and frequent retention of constituent loads occurred because the relatively small wetland area was not a major source of organic material, despite the stream's relatively long residence time within the reach. Plentiful DO was available in this reach to oxidize chemical compounds and thereby reduce stream loads of these substances. Although DO concentrations increased from 75 to 92 percent of saturation through the upper reach, net primary productivity decreased from 1.1 to $-0.7\left(\mathrm{~g} \mathrm{O}_{2} / \mathrm{m}^{3}\right) / \mathrm{d}$, mainly because of the dense canopy cover that inhibited photosynthetic production by limiting sunlight on the water in the downstream part of this reach.

The middle reach is characterized by low DO concentrations, a large contributing wetland area, and a long stream residence time. The middle reach acted as an effective sink for DO, consuming from 0 to $8,000 \mathrm{~kg}$ per season. This oxygen depletion is similar to a stream's response to a waste-water treatmentplant discharge. In this reach, the wetland typically increased stream loads of dissolved organic carbon, hydrogen ion, dissolved iron, ammonium nitrogen, dissolved aluminum, and hydrolyzable-plus-orthophosphate phosphorus. Discharges were about 7,000 kg per season dissolved organic carbon, $0.5 \mathrm{~kg}$ per season hydrogen ion, and ranged from about 800 to $1,050 \mathrm{~kg}$ per season iron, 30 to $200 \mathrm{~kg}$ per season ammonium nitrogen, 300 to $2,200 \mathrm{~kg}$ per season alkalinity, 30 to $50 \mathrm{~kg}$ per season dissolved aluminum, and 20 to $30 \mathrm{~kg}$ per season hydrolyzable-plus-orthophosphate phosphorus. Chemical discharges from this reach had a seasonal trend, whereby use uptake of nitrite-plus-nitrate nitrogen and sulfate was pronounced during periods of increased vegetation and microbial activity. Negative wetland-derived discharges ranged from about 5 to $50 \mathrm{~kg}$ per season nitrite-plus-nitrate nitrogen and 500 to $1,500 \mathrm{~kg}$ per season sulfate. DO concentrations decreased from 52 to 29 percent of saturation, net primary productivity values decreased from -5.3 to $-12\left(\mathrm{~g} \mathrm{O}_{2} / \mathrm{m}^{3}\right) / \mathrm{d}$, and color values increased from 25 to $300 \mathrm{Pt}-\mathrm{Co}$ units through the middle reach. The influx of highly colored water from the organic layer in the wetland reduced light penetration, limiting photosynthetic oxygen production. Furthermore, this highly colored water indicates that the organic acid concentrations are high enough to be associated with a chemical oxygen demand. In general, the low oxygen concentrations of the middle reach appeared to limit aerobic processes: the constituent loads that increase through this reach are products of anaerobic degradation. Stream-water residence time has a strong effect on stream-water quality in this reach. By prolonging the period over which the stream receives drainage from organic peat and by facilitating the inflow of oxygen-demanding organic acids, the increased residence time affects the biochemical transformation of water-quality constituents. Oxygen consumption by microbial action and chemical oxidation exceeds production by photosynthesis and physical reaeration. During periods of increased biological activity, sulfate reduction by microbial action and nitrate uptake by plants exceeds inflow from incoming stream water, resulting in removal of these constituents.

The lower reach is also characterized by a large contributing wetland area. However, unlike the middle reach, the lower reach had intermediate oxygen concentrations and very short residence time. The wetland in the lower reach typically increased loads of ammonium nitrogen, hydrogen ion, dissolved aluminum, and hydrolyzable-plus-orthophosphate phosphorus, but consistently consumed alkalinity. Although this final reach consumed 700 to $1,700 \mathrm{~kg}$ per season of alkalinity, the wetland as a whole in- 
creased alkalinity in the stream. Chemical discharges in the lower reach were about 20 to $150 \mathrm{~kg}$ per season ammonium nitrogen, 1 to $2 \mathrm{~kg}$ per season hydrogen ion, 20 to $70 \mathrm{~kg}$ per season dissolved aluminum, and 5 to $10 \mathrm{~kg}$ per season hydrolyzable-plus-orthophosphate phosphorus. Discharges of nitrite-plus-nitrate nitrogen and sulfate did not follow the seasonal trend demonstrated by the middle reach. The increase in DO load seemed to facilitate aerobic degradation. Constituents, such as dissolved organic carbon and dissolved iron, are oxidized more readily in the lower reach than in the middle reach. Also, the short residence time of stream water in this reach suggests that inflow to the reach is adequate to provide nutrients for plant uptake. Apparently, the short residence time of the stream water increased dilution of the inflowing peat water more than it did in the middle reach. Therefore, the inflow of peat water was not sufficient to contribute to a DO demand or cause a seasonal trend in sulfate and nitrate transformations in this reach.

The entire wetland contributed only small gains in stream-water concentrations of ammonium nitrogen, nitrite-plus-nitrate nitrogen, sulfate, dissolved aluminum, and hydrolyzable-plus-orthophosphate phosporus. Generally, pH and aluminum concentrations were stabilized by the chemical changes caused by the wetland. Median concentrations of ammonium nitrogen increased from 0.02 to $0.06 \mathrm{mg} / \mathrm{L}$, nitriteplus-nitrate nitrogen increased from $<0.1$ to 0.11 $\mathrm{mg} / \mathrm{L}$, sulfate increased from 7.3 to $10.5 \mathrm{mg} / \mathrm{L}$, dissolved aluminum increased from 115 to $130 \mu \mathrm{g} / \mathrm{L}$, and hydrolyzable-plus-orthophosphate phosphorus increased from $<0.01$ to $0.03 \mathrm{mg} / \mathrm{L}$. Changes in $\mathrm{pH}$ levels were also small; median values increased from 5.66 to 5.86 .

The entire wetland contributed gains in streamwater concentrations of dissolved organic carbon. $\mathrm{Me}-$ dian concentrations gained $7.7 \mathrm{mg} / \mathrm{L}$ through the wetland. Median alkalinity concentrations increased from 1.2 to $2.2 \mathrm{mg} / \mathrm{L}$ through the entire wetland, adding slightly to the buffering capacity of the stream water. During the spring of both study years, the wetland was an oxygen sink, consuming more oxygen than it contributed. During the summers of both years, the wetland was not a significant contributor of oxygen. DO variations are inversely correlated with variations in dissolved organic carbon and color. Color, an indicator of organic acids that contribute to buffering capacity, also increased from 55 to $500 \mathrm{Pt}$-Co units. Iron concentrations increased also, with most of the gains occurring in the soluble form. Median concentrations of dissolved iron increased from 120 to $1,010 \mu \mathrm{g} / \mathrm{L}$ through the wetland.

It appears that the wetland, with its store of organic material, provides the physical and biochemical environment for modification of water-quality constituents. The wetland system is much like the dystrophic systems described in the literature. In the headwater, the stream originates as an oligotrophic system, characterized by positive productivity rates, high DO saturation concentrations, and high water transparency. As it flows through the subbasins affected by wetland areas, the stream functions as a dystrophic system, with low net productivity rates, depressed concentrations of DO, and increased loads of dissolved organic carbon, organic acids, hydrogen ion, ammonium nitrogen, iron, and other products associated with peat-water chemistry. In stream reaches that have large ratios of wetland area to total intervening drainage area, net oxygen-productivity rates are negative. More oxygen is consumed in these areas than is produced by photosynthesis as chemicaloxygen demands increase. Additionally, basin morphometry acts to affect the trophic state of the system. Low stream gradient and velocity-suppressing wetland vegetation greatly increase the residence time in the stream, thereby facilitating the interaction of water with organic peat.

\section{REFERENCES CITED}

Alden, W.C., 1924, The physical features of central Massachusetts, in Campbell, M.R., 1925, Contributions to the geography of the United States 1923-1924: U.S. Geological Survey Bulletin 760, p. 13-105.

Boelter, D.H., and Verry, E.S., 1977, Peatland and water in the northern lake states: St. Paul, Minnesota, U.S. Department of Agriculture Forest Service General Technical Report NC-31, 22 p.

Cowardin, L.M., Carter, Virginia, Golet, F.C., and LaRoe, E.T., eds., 1979, Classification of wetlands and deepwater habitats of the United States: U.S. Fish and Wildlife Service, FSW/OBS-79/31, $103 \mathrm{p}$.

Duan, N., 1983, Smearing estimate: A nonparametric retransformation method: Journal of the American Statistical Association, v. 87, no. 383, p. 605610. 
Freeze, R.A., 1972, Role of subsurface flow in generating surface runoff, 2. Upstream source areas: Water Resources Research, v. 8, p. 1272-1283.

Hem, J.D., 1970, Study and interpretation of the chemical characteristics of natural water: U.S. Geological Survey Water-Supply Paper 1473, $363 \mathrm{p}$.

Hubbard, E.F., Kilpatrick, F.A., Martens, L.A., and Wilson, J.R., Jr., 1982, Measurement of time of travel and dispersion in streams by dye tracing: U.S. Geological Survey Techniques of Water-Resources Investigations, book 3, chap. A9, 44 p.

Hutchinson, G.E., 1957, A treatise on limnology: vol. II. Introduction to lake biology and the limnoplankton: New York, New York, John Wiley \& Sons, Inc, 1115 p.

Manahan, S.E., 1975, Environmental Chemistry, Second Edition: Boston, Massachusetts, Willard Grant Press, 532 p.

Martinec, J., 1975, Subsurface flow from snowmelt trace by tritium: Water Resources Research, v. 11 , p. 496-497.

Martinec, J., Siegenthaler, H., Oeschger, H., and Tongiorgi, E., 1974, New insight into the runoff mechanism by environmental isotopes, in Proceedings symposium on isotope techniques in ground-water hydrology, I.A.E.A., Vienna Austria, v. 1, p. 129-143.

Massachusetts Division of Water Pollution Control, 1986, Massachusetts surface water quality standards, 1985: 314 CMR 4.00-4.05.

McKnight, Diane, Thurman, E.M., Wershaw, R.L., and Hemond, Harold, 1985, Biogeochemistry of aquatic humic substances in Thoreau's Bog, Concord, Massachusetts: Ecology, v. 66, no. 4, p. 1339-1352.

Miles, C.J. and Brezonik, P.L., 1981, Oxygen consumption in humic-colored waters by photochemical ferrous-ferric catalytic cycle: Environmental Science and Technology, v. 15, no. 9, p. 1089-1095.

Mitsch, W.J., and Gosselink, J.G., 1986, Wetlands: New York, New York, Van Nostrand Reinhold Company, 537 p.
Nordstrom, D.K. and Ball, J.W., 1986, The geochemical behavior of aluminum in acidified surface waters: Science, v. 232, p. 54-56.

Parker, G.W. and Gay, F.B., 1987, Equation to estimate reaeration coefficient in Massachusetts streams: U.S. Geological Survey Water Resources Investigation Report 86-4111, $69 \mathrm{p}$.

Parker, G.W. and Suurballe, N.C., 1988, Differences in oxygen productivity rates and reaeration coefficients for wetland reaches of Natty Pond Brook, Massachusetts: in Proceedings of the national wetland symposium: wetland hydrology, September 16-18, 1987, Chicago, Illinois, p. 205-212.

Rantz, S.E., ed., 1982, Measurement and computation of streamflow: volume 2. computation of discharge: U.S. Geological Survey Water-Supply Paper 2175, p. 337-338.

Resource Mapping-Land Information Systems, 1985, Digital land-use data for Hubbardston, Massachusetts: University of Massachusetts, Department of Forestry and Wildlife Management.

Richardson, C.J., Tilton, D.L., Kadlec, J.A., Chamie, J.P.M., and Wentz, W.A., 1978, Nutrient dynamics of northern wetland ecosystems, in Good, $R$. E., Whigham, D. F., and Simpson, R. L., eds., Freshwater wetlands: ecological processes and management potential: New York, New York, Academic Press, p. 217-241.

Sklash, M.G., Farvolden, R.N., and Fritz, P., 1976, A conceptual model of watershed response to rainfall, developed through the use of oxygen-18 as a natural tracer: Canadian Journal of Earth Sciences, v. 13, no. 2, p. 271-283.

Stephens, D.W. and Jennings, M.E., 1976, Determination of primary productivity and community metabolism in streams and lakes using diel oxygen measurements: U.S. Geological Survey Computer Program Documentation, program no. J330, 100 p.

Thornthwaite, C.W. and Mather, J.R., 1957, Instructions and tables for computing potential evapotranspiration and the water balance: Publications in Climatology, v. 10, no. 3, Drexel Institute of Technology, p. 185-311.

Thurman, E.M., 1985, Organic Geochemistry of Natural Waters: Boston, Massachusetts, Martinus Nijhoff / Dr. W. Junk Publishers, 497 p. 
U. S. Fish and Wildlife Service, Office of Biological Services, 1975, National Wetland Inventory Map of Barre Quadrangle, Massachusetts: Newton Corner, Massachusetts, 1 sheet, scale 1:25,000.

Wetzel, R.G., 1975, Primary production, in Whitton, B. A., ed., River ecology: Berkeley, California, University of California Press, p. 230-247.

Wieder, R.K., 1985, Peat and water chemistry at Big Run Bog, a peatland in the Appalachian mountains of West Virginia, USA: Biogeochemistry, v. 1, p. 277-302.

Winter, T.C., 1981, Uncertainties in estimating the water balance of lakes: American Water Resources Association Water Resources Bulletin, v. 17 , no. 1, p. $82-115$. 